\title{
CONGENITAL MALFORMATIONS OF THE CENTRAL NERVOUS SYSTEM
}

\section{I-A SURVEY OF 930 CASES*}

\author{
BY \\ R. G. RECORD and THOMAS MCKEOWN \\ From the Department of Social Medicine, University of Birmingham.
}

\section{INTRODUCTION}

Of the causes of stillbirths and infant mortality which have not shared in the general improvement during the last fifty years easily the most important are the congenital malformations. At the beginning of the present century, when ideas about their aetiology were turning from mysticism to morbid anatomy, their investigation could have been regarded as an interesting academic exercise, which might add something to knowledge of the intrauterine environment or of human genetics, but could make no considerable contribution to the accountancy of preventable deaths. This is not the position to-day. The intervening years have added little to our knowledge of the aetiology of the malformations, but the effectiveness of preventive measures against other causes of infant death before and after birth has enormously altered their relative contribution to the total deaths. In the white population of New Zealand, for example, they recently accounted for nearly one-fifth of the deaths under one year (Leitch, 1944), and these figures are being approached in this country, where infant mortality attributed to malformations has shown a slight absolute and a large relative increase (Table I). Scottish data for stillbirths and first-year deaths show that in the six years to 1945,10 per cent. of all foetuses that reached viable age were born dead or died in the first year of life; more than 10 per cent. of these deaths were ascribed to congenital malformations (Table II, overleaf). Expressed differently, 1 per cent. of all foetuses alive in the 28th week of pregnancy died from congenital malformations before the first birthday.

CAusation.-The subject has been reviewed extensively (Warkany, 1947; Gruenwald, 1947), and it will suffice to recall the results of the main lines of enquiry. In lower animals, where the * This research was assisted by a grant from the Birmingham
University Students' Social Service Fund. embryos are in intimate contact with a changing environment, it was readily demonstrated that external factors can modify the course of embryonic development. Unspecific physical agents, such as $x$ rays, ultra-violet light, mechanical shaking or temperature changes, and a large number of chemical agents which inhibit growth, gave rise in a variety of species to congenital deformities. The application of some of this work to the more uniform uterine environment of mammals is doubtful, but there is also evidence from the animal laboratory that the mammalian foetus may be deformed by external influences. On the other hand, certain malformations in animals are undoubtedly genetically determined, though some of them bear little resemblance to the common human deformities.

It is difficult to assess the relevance of this evidence, much of it on invertebrates and lower vertebrates, to the corresponding problem in man. The

TABLE I $\dagger$

QUinQuenNial INFANT MORTALITY Rates For ENGLAND AND WALES (1901-1945)

\begin{tabular}{c|c|c|c|c}
\hline \multirow{2}{*}{ Period } & \multicolumn{2}{c|}{$\begin{array}{c}\text { Infant Deaths per } \\
1,000 \text { Live Births }\end{array}$} & $\begin{array}{c}\text { Rates expressed as a } \\
\text { percentage of those } \\
\text { from 1901 to 1905 }\end{array}$ \\
\cline { 2 - 4 } & $\begin{array}{c}\text { From Con- } \\
\text { genital } \\
\text { Malforma- } \\
\text { tions }\end{array}$ & $\begin{array}{c}\text { From all } \\
\text { Causes }\end{array}$ & $\begin{array}{c}\text { From Con- } \\
\text { genital } \\
\text { Malforma- } \\
\text { tions }\end{array}$ & $\begin{array}{c}\text { From all } \\
\text { Causes }\end{array}$ \\
\hline $1901-05$ & $4 \cdot 33$ & 138 & 100 & 100 \\
$1906-10$ & $4 \cdot 94$ & 117 & 114 & 85 \\
$1911-15$ & $3 \cdot 85$ & 110 & 89 & 80 \\
$1916-20$ & $4 \cdot 04$ & 90 & 93 & 65 \\
$1921-25$ & $4 \cdot 32$ & 76 & 100 & 55 \\
$1926-30$ & $4 \cdot 94$ & 68 & 114 & 49 \\
$1931-35$ & $5 \cdot 85$ & 62 & 135 & 45 \\
$1936-40$ & $6 \cdot 11$ & 55 & 141 & 40 \\
$1941-45$ & $5 \cdot 97$ & 50 & 138 & 36 \\
\hline
\end{tabular}

† Martin, W. J. (1949). Brit. med. J., 1, 438. 
TABLE II*

Stillbirth aNd INfaNt Mortality Rates for Scotland (1939-1945)

\begin{tabular}{|c|c|c|c|c|c|c|c|c|}
\hline \multirow{2}{*}{ Year } & \multicolumn{2}{|c|}{$\begin{array}{l}\text { Stillbirths per } 1,000 \\
\text { Total Births }\end{array}$} & \multicolumn{2}{|c|}{$\begin{array}{l}\text { Infant Deaths per } 1,000 \\
\text { Live Births }\end{array}$} & \multicolumn{2}{|c|}{$\begin{array}{l}\text { Combined Stillbirths and } \\
\text { Infant Deaths per } \\
1,000 \text { Total Births }\end{array}$} & \multirow{2}{*}{\multicolumn{2}{|c|}{$\begin{array}{l}\text { Contribution of } \\
\text { Malformations to } \\
\text { Total Deaths } \\
\%\end{array}$}} \\
\hline & $\begin{array}{l}\text { From all } \\
\text { Causes }\end{array}$ & $\begin{array}{c}\text { From Foetal } \\
\text { Defects }\end{array}$ & $\begin{array}{l}\text { From all } \\
\text { Causes }\end{array}$ & $\begin{array}{l}\text { From Con- } \\
\text { genital } \\
\text { Malforma- } \\
\text { tions }\end{array}$ & $\begin{array}{l}\text { From all } \\
\text { Causes }\end{array}$ & $\begin{array}{l}\text { From Con- } \\
\text { genital } \\
\text { Malforma- } \\
\text { tions }\end{array}$ & & \\
\hline $\begin{array}{l}1939 \\
1940 \\
1941 \\
1942 \\
1943 \\
1944 \\
1945\end{array}$ & $\begin{array}{l}42 \cdot 2 \\
42 \cdot 1 \\
39 \cdot 6 \\
38 \cdot 2 \\
35 \cdot 6 \\
32 \cdot 5 \\
33 \cdot 0\end{array}$ & $\begin{array}{l}5 \cdot 83 \\
6 \cdot 09 \\
6 \cdot 53 \\
5 \cdot 71 \\
6 \cdot 07 \\
5.93 \\
6 \cdot 65\end{array}$ & $\begin{array}{l}68 \cdot 5 \\
78 \cdot 3 \\
82 \cdot 7 \\
69 \cdot 3 \\
65 \cdot 2 \\
65 \cdot 0 \\
56 \cdot 2\end{array}$ & $\begin{array}{l}6 \cdot 35 \\
6 \cdot 05 \\
6 \cdot 81 \\
7 \cdot 12 \\
6 \cdot 21 \\
5 \cdot 96 \\
5 \cdot 56\end{array}$ & $\begin{array}{r}107 \cdot 9 \\
117 \cdot 1 \\
119.0 \\
104 \cdot 8 \\
98 \cdot 5 \\
95 \cdot 4 \\
87.2\end{array}$ & $\begin{array}{l}11 \cdot 9 \\
11 \cdot 9 \\
13 \cdot 1 \\
12 \cdot 6 \\
12 \cdot 1 \\
11 \cdot 7 \\
12 \cdot 0\end{array}$ & $\begin{array}{l}11 \cdot 0 \\
10 \cdot 1 \\
11 \cdot 0 \\
12 \cdot 0 \\
12 \cdot 3 \\
12 \cdot 3 \\
13 \cdot 8\end{array}$ & 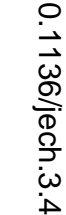 \\
\hline 1939-1945 & $37 \cdot 5$ & $6 \cdot 11$ & $69 \cdot 3$ & $6 \cdot 30$ & $104 \cdot 2$ & $12 \cdot 2$ & $11 \cdot 7$ & $\vec{\infty}$ \\
\hline
\end{tabular}

importance of the uterine environment has been stressed by pathologists who have cited the high incidence of pathological embryos in ectopic pregnancies, and in association with placenta praevia where the ovum embeds in or near the lower uterine segment. It has been suggested that some deformities are produced mechanically by pressure on the foetus, but this is unlikely to explain the more common and more lethal malformations. Infections in the mother during pregnancy have also been considered since the report that a history of rubella could be elicited in a number of cases; most observations on this subject are open to the criticism that the association may be fortuitous, for as a rule the incidence of the disease in pregnant women who produce normal children is unknown.

Conclusive evidence about the influence of heredity in man is available only for the exceptional malformations in which the recorded incidence in families is in accord with the known laws of inheritance. In many other malformations an incidence higher than average is observed in the relatives of a malformed propositus, but this information does not, of course, permit us to separate environmental and genetic effects. Twin studies are few, and must be interpreted cautiously in view of the special difficulty of establishing the homozygosity of a uniovular pair.

It is an indication of our increased awareness of the difficulties that we are no longer content to examine as exclusive alternatives the possibilities of genetic or environmental causes for most observations in human beings. In this matter we are indebted particularly to Hogben (1933), who has drawn our attention to the extent to which we have been misled by the emphasis on experience of highly standardized animal stocks, observed in the laboratory under carefully controlled conditions On existing evidence we can neither support nordismiss the possibility of a contribution from inheritance to the origin of most malformatiogs; but must accommodate in our conception the interdependence of genetic and environmerfas variables, with the attendant difficulty of assessing the relative contribution of each. The congenitab malformations have now been considered from this viewpoint (Lenart, 1941; Gruenwald, 1947; Pen $\overrightarrow{\bar{O}}$ rose, 1948; Holt, 1948) and the question will be examined more fully in a later communication.

SOURCES OF DATA.-In collecting data on human. malformations we are handicapped by the fact tha? there are no satisfactory sources of information? about individuals for whom the malformation is no $\underline{B}$. certified as the cause of death. We may conven: iently consider sources of data in relation to deaths at four different periods.

(a) Deaths in utero before the 28th Week of Gestation.-Stillbirths are not notified in Great Britain until the 28th week of gestation, $\uparrow$ and fo information earlier than this time we rely mainly oro observations of pathologists who examine the aborted foetus (for example, Mall, 1917; Hertig an\& Livingstone, 1944). Inevitably such reports are్ incomplete, since only a proportion of abortions come to medical attention. This source is occa? sionally supplemented by material which becomes available at operations on the pregnant uterus (Rock and Hertig, 1948).

$\dagger$ This date is not the same in every country. 
TABLE III

INCIDENCE of Malformations in Hospital Series

\begin{tabular}{|c|c|c|c|c|c|c|}
\hline $\begin{array}{c}\text { Country, Author, } \\
\text { and Date }\end{array}$ & Place & $\begin{array}{l}\text { Total } \\
\text { Numbers } \\
\text { of Births } \\
\text { in Series }\end{array}$ & $\begin{array}{c}\text { Malformations } \\
\text { per 1,000 Births } \\
\text { (not necessarily } \\
\text { fatal) }\end{array}$ & $\begin{array}{c}\text { Stillbirths due } \\
\text { to Malforma- } \\
\text { tions per 1,000 } \\
\text { Total Births }\end{array}$ & $\begin{array}{c}\text { Neonatal } \\
\text { Deaths due to } \\
\text { Malformations } \\
\text { per } 1,000 \text { Live } \\
\text { Births }\end{array}$ & Remarks \\
\hline \multicolumn{7}{|l|}{ United Kingdom } \\
\hline Malpas, 1937 & Liverpool & 13,964 & 21 & - & - & $\begin{array}{l}50 \% \text { of malformations } \\
\text { were cerebrospinal. }\end{array}$ \\
\hline $\begin{array}{l}\text { Allen, Macaffee, } \\
\text { and Biggart, } \\
1943\end{array}$ & Belfast & 6,314 & - & - & $7 \cdot 3$ & $\begin{array}{l}49 \% \text { of malformations } \\
\text { were cerebrospinal. }\end{array}$ \\
\hline Baird, 1947 & Aberdeen & 3,296 & - & $4 \cdot 9$ & $5 \cdot 3$ & Primiparae only. \\
\hline Drillien, 1947 & Edinburgh & 7,599 & - & $9 \cdot 3$ & $5 \cdot 4$ & - \\
\hline \multicolumn{7}{|l|}{ America } \\
\hline $\begin{array}{l}\text { Javert and } \\
\text { Stander, } 1943\end{array}$ & New York & 27,000 & $29 \cdot 5$ & - & 一 & $\begin{array}{l}\text { Includes a number' of } \\
\text { minor malformations. }\end{array}$ \\
\hline $\begin{array}{l}\text { D'Esopo and } \\
\text { Marchetti, } \\
1942\end{array}$ & New York & 25,823 & $5 \cdot 5$ & - & - & $\begin{array}{l}\text { Includes only fatal } \\
\text { malformations. }\end{array}$ \\
\hline $\begin{array}{l}\text { Newton and } \\
\text { McLean, } 1947\end{array}$ & Bridgeport & 15,421 & $8 \cdot 4$ & - & - & $\begin{array}{l}65 \% \text { of malformations } \\
\text { were cerebrospinal. }\end{array}$ \\
\hline $\begin{array}{l}\text { Potter and } \\
\quad \text { Adair, } 1943\end{array}$ & Chicago & 27,321 & - & $2 \cdot 4$ & $2 \cdot 4$ & $\begin{array}{l}35 \% \text { of malformations } \\
\text { were cerebrospinal. }\end{array}$ \\
\hline $\begin{array}{l}\text { Potter and } \\
\text { Dieckmann, } \\
1948\end{array}$ & Chicago & 17,657 & - & $1 \cdot 2$ & $2 \cdot 9$ & - \\
\hline
\end{tabular}

(b) Deaths in utero after the 28th Week of Gestation.-After the 28th week stillbirths are notified, and from this time national statistics record information extracted from the notification card. In England and Wales this does not include the certified cause of the stillbirth, but since 1939 the cause has been recorded by the Registrar-General for Scotland, adding greatly to the value of the data which can be extracted on malformations.

(c) 'Deaths in the First Year of Life. - In England and Wales as well as in Scotland, the cause of subsequent death is, of course, certified for live births, and the record is particularly useful in the case of the more lethal malformations which cause death in the first year of life.

(d) Deaths after the First Year of Life.-Information about malformed individuals who die after the first year of life is less satisfactory, since the fact of survival to this date indicates that the malformations are less serious, and therefore less likely to appear ultimately as the cause of death.
National statistics are, of course, subject to errors of diagnosis. Malformations such as anencephalus and spina bifida are unlikely to be missed, but others are not reliably diagnosed without an autopsy. On the other hand, it is probably not uncommon for the presence of an internal malformation to be inferred where it does not exist, or for deaths due to other causes to be attributed to malformations. For example, it is likely that the deaths of some infants born in a state of asphyxia livida are erroneously certified as due to congenital heart disease (Cruickshank, 1930). Yet another source of error is introduced by the incrimination of a relatively minor malformation (for example, hare-lip or cleft palate) as the cause of a stillbirth or death when the real cause is unknown.

In view of these difficulties, records of hospitals where a high proportion of cases were examined post mortem are of interest (Table III). The fact that the reported incidence of congenital malformations varied greatly from one hospital to another 
TABLE IV*

Stillbirths and Infant Deaths due to Cenntral Nervous Malformations in Scotland (1941-1945)

\begin{tabular}{|c|c|c|c|c|c|c|}
\hline \multirow[b]{2}{*}{ Year } & \multicolumn{3}{|c|}{ Stillbirths } & \multicolumn{3}{|c|}{ Infant Deaths } \\
\hline & $\begin{array}{l}\text { Due to all } \\
\text { foetal defects }\end{array}$ & $\begin{array}{c}\text { Due to } \\
\text { anencephalus, } \\
\text { spina bifida, } \\
\text { and } \\
\text { hydrocephalus }\end{array}$ & $\begin{array}{c}\text { Percentage of } \\
\text { Malformations } \\
\text { involving } \\
\text { Central } \\
\text { Nervous } \\
\text { System }\end{array}$ & $\begin{array}{c}\text { Due to all } \\
\text { Congenital } \\
\text { Malformations }\end{array}$ & $\begin{array}{c}\text { Due to spina } \\
\text { bifida and } \\
\text { hydrocephalus }\end{array}$ & $\begin{array}{c}\text { Percentage of } \\
\text { Malformations } \\
\text { involving } \\
\text { the Nervous } \\
\text { System }\end{array}$ \\
\hline $\begin{array}{l}1941 \\
1942 \\
1943 \\
1944 \\
1945\end{array}$ & $\begin{array}{l}610 \\
538 \\
596 \\
588 \\
598\end{array}$ & $\begin{array}{l}391 \\
472 \\
399 \\
396 \\
442\end{array}$ & $\begin{array}{l}64 \\
88 \\
67 \\
67 \\
74\end{array}$ & $\begin{array}{l}611 \\
646 \\
588 \\
572 \\
483\end{array}$ & $\begin{array}{l}241 \\
266 \\
231 \\
215 \\
171\end{array}$ & $\begin{array}{l}39 \\
41 \\
39 \\
38 \\
35\end{array}$ \\
\hline - Total & 2,930 & 2,100 & 72 & 2,900 & 1,124 & 39 \\
\hline
\end{tabular}

indicates, as might be expected, that representative statistics cannot be collected from this source. It is also possible to supplement the sources of data listed above by field enquiry. This method has been used with profit by Penrose $(1934 ; 1946)$ and Murphy (1940). We have therefore chosen to collect information by field enquiry on all malformations of certain specified types notified to a large Local Authority over a period of years.

The Present EnQuiry.-The evidence suggests that congenital malformations in man do not form a homogenous group of uniform aetiology, and this view is supported by observations of the sex ratio: the proportion of males to females in pyloric stenosis is four to one, and in anencephalus one to three; the sex ratios of other malformations lie between these extremes. Investigations are therefore more likely to be of value if restricted to one type of deformity which occurs with sufficient frequency to furnish adequate numbers, and for this reason, we have confined our attention to the malformations of the nervous system. Table IV shows that in the years 1941 to 1945 in Scotland, they accounted for at least $\uparrow 72$ per cent. of stillborn and 39 per cent. of live born malformations which died in the first year of life, or for 55 per cent. of the combined total $(5,830)$. The total births in the same period were 474,959 , and central nervous malformations were thus responsible for the deaths of 0.68 per cent. of all infants born.

Study of this group has the further advantage that its members are readily identified at birth from external appearances so that errors of diagnosis are

$\uparrow$ Not all malformations of the nervous system are shown separately. unlikely, except occasionally in hydrocephalus, where perforation of the head may be necessary'to effect delivery, and in the premature infant whereo the relatively large head may be erroneouslyo diagnosed as hydrocephalus. Notifications of still $\overrightarrow{-}$ births and infant deaths ensure the collection of alle cases of anencephalus, and of almost all cases क्षf spina bifida with occasional exceptions such spina bifida occulta and mild examples of mening cele. The only serious statistical loss consists of those cases of hydrocephalus compatible with lifeo for a number of years. A few deaths of infants froma acquired hydrocephalus may also be erroneously $\overrightarrow{\hat{\sigma}}$ attributed to congenital causes, where the history of infection is overlooked.

We were fortunate in having access to the records of the Maternity and Child Welfare Department of the City of Birmingham, which for a number of years has obtained information on all stillbirths and neonatal deaths, by means of a questionnaire completed. by the doctor or midwife in charge of the case? When returned, the form is scrutinized by a medica $\mathrm{R}$ officer of the department, and the informations entered into a register. From this register, we extracted information for the eight years 1940 to으. 1947 about all malformations of the central nervous system which were certified as the cause of death of stillbirths or of infants in the first year of life. Thes data available from this source for stillbirths and neonatal deaths were:

(1) name, address, and municipal ward;

(2) date and place of birth;

(3) sex, single or twin, legitimacy;

(4) brief details of results of previous pregnancies.

(5) details of all malformations, and other condi tions contributing to death. 
TABLE V

The Numbers of Central Nervous Malformations of Different Types in 930 consecutive Cases born in BIRMINGHAM (1940-1947)

\begin{tabular}{|c|c|c|c|c|c|}
\hline \multirow{2}{*}{ Group } & \multirow{2}{*}{ Sub-group** } & \multicolumn{3}{|c|}{ Number of } & \multirow{2}{*}{ Total } \\
\hline & & Stillbirths & $\begin{array}{c}\text { Neonatal } \\
\text { Deaths }\end{array}$ & $\begin{array}{l}\text { Later Infant } \\
\text { Deaths }\end{array}$ & \\
\hline Anencephalus & 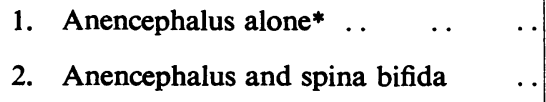 & $\left.{ }_{33}^{314}\right\}^{347}$ & $\begin{array}{r}18 \\
1\end{array} \mid 19$ & - & $34 \int^{332} 366$ \\
\hline Spina bifida & $\begin{array}{l}\text { 3. Spina bifida alone }{ }^{*} \dagger \quad . \quad \ldots \\
\text { 4. Spina bifida and hydrocephalus } \\
\text { 5. Spina bifida and encephalocele } \\
\text { 6. Spina bifida, hydrocephalus, and en- } \\
\begin{array}{lll}\text { cephalocele } & . .\end{array}\end{array}$ & $\left.\begin{array}{r}49 \\
68 \\
2\end{array}\right\} 120$ & $\left.\begin{array}{r}144 \\
56 \\
2\end{array}\right\} 202$ & $\begin{array}{r}62 \\
5 \\
- \\
-\end{array}$ & $\left.\begin{array}{r}255 \\
129 \\
4 \\
1\end{array}\right\}$ \\
\hline Hydrocephalus & 7. Hydrocephalus alone* & 112 & 24 & 14 & 150 \\
\hline Others & $\begin{array}{ccccc}\text { 8. Encephalocele alone* } & \ldots & \ldots \\
\text { 9. All other central nervous malforma- } & \text {.. } \\
\text { tions } \ddagger & \ldots & \ldots & \ldots & \ldots\end{array}$ & ${ }_{3}^{2} 5$ & $\left.\begin{array}{l}9 \\
6\end{array}\right\} 15$ & -75 & \}$_{14}^{11} 25$ \\
\hline Total Central $\mathrm{I}$ & ervous Malformations & 584 & 260 & 86 & 930 \\
\hline
\end{tabular}

* Excludes the co-existence of a second central nervous malformation.

" "Spina bifida" includes spinal meningocele, meningomyelocele, and myelocele.

\# "Other central nervous malformations" were: microcephalus-8; unspecified congenital cerebral defect-4; occipital meningocele-2.

* Numerals are referred to in Fig. 1.

For live births, the date and place of death were also recorded. The details listed above are now collected for all infant deaths in the city, but for seven of the eight years covered by the survey the only data available from central sources for deaths after the neonatal period, were the name and address, age at death, place and cause of death. In such cases there was no difficulty in completing the record in the course of the subsequent investigation.

Visits were made to the homes of all mothèrs of the malformed births, and of a control group of approximately equal size, obtained by selecting every two-hundredth name in the registers of live and still births for the same years (1940 to 1947). The visits were completed in the period November, 1947, to October, 1948, by a team of female investigators, most of whom had been trained as almoners or in some other branch of social work. In each case where the mother could be interviewed at her original home or elsewhere in the city a field enquiry card was completed with her assistance. Information was recorded as follows:

(1) menstrual history (age at onset; mean length of the cycle; duration of flow);

(2) age at marriage;
(3) reproductive history (details of all conceptions);

(4) history of the pregnancy resulting in the birth of the propositus (illness; work during pregnancy);

(5) information about the father (age; occupation; blood relationship to the mother);

(6) rent (included as an index of social circumstances);

(7) family history of congenital malformations.

No attempt was made to trace mothers who had left the city; the proportions lost in the malformation and control series are discussed below.

\section{ObServations on 930 Consecutive Malformations of the Central' Nervous System§}

Classification AND INCIDENCE.-In the years 1940 to 1947 , malformations of the central nervous system were certified in Birmingham as the cause of death of 930 stillbirths and first year deaths. Table $\mathrm{V}$ (see also Fig. 1, overleaf) gives the numbers attributed to each type of malformation, which have been grouped into four main divisions: anencephalus; spina bifida; hydrocephalus; others. This is the classification suggested in the International

$\S$ Data from Maternity and Child Welfare Department records. 
TABLE VI

STIllbirth AND INFANT MORTALITY RATES DUE TO Malformations of the CENTRAL Nervous SyStem IN BIRMINGHAM (1940-1947)

\begin{tabular}{l|c|c|c}
\hline $\begin{array}{c}\text { Type of } \\
\begin{array}{c}\text { Malforma- } \\
\text { tion }\end{array}\end{array}$ & $\begin{array}{c}\text { Stillbirth } \\
\text { rate per } \\
1,000 \text { Total } \\
\text { Births }\end{array}$ & $\begin{array}{c}\text { Infant } \\
\text { Mortality } \\
\text { rate per } \\
1,000 \text { Live } \\
\text { Births }\end{array}$ & $\begin{array}{c}\text { Total Deaths } \\
\text { per 1,000 } \\
\text { Total Births }\end{array}$ \\
\hline $\begin{array}{l}\text { Anencephalus } \\
\text { Spina bifida }\end{array}$ & $2 \cdot 192$ & 0.123 & $2 \cdot 312$ \\
\hline $\begin{array}{l}\text { Hydro- } \\
\text { cephalus }\end{array}$ & 0.758 & 1.747 & 2.457 \\
\hline $\begin{array}{l}\text { Others } \\
\text { Total }\end{array}$ & 0.032 & 0.130 & 0.158 \\
\hline
\end{tabular}

Statistical Classification of Diseases, Injuries, and Causes of Death (1948), which does not, however, show where births with more than one malformation (for example, spina bifida with hydrocephalus) are placed. The three groups, anencephalus, spina bifida, and hydrocephalus, are also used by the Registrar-General for Scotland in his valuable statistics on stillbirths, but the fact that the precise composition of the divisions is not indicated does not permit us to identify them with our own, and he includes all other malformations of the central ${ }^{\circ}$ nervous system with "other specified defects". $\frac{3}{8}$

If the data are grouped, the placing of combined? malformations is important in two types which are $\overrightarrow{\vec{*}}$ comparatively common in Birmingham records:anencephalus with spina bifida, and spina bifida with hydrocephalus. Differences in the proportion of $\frac{\bar{m}}{\mathrm{~N}}$ stillbirths and in the sex ratio of each malformation suggest the need for caution in allocating to any of $\stackrel{\mathcal{Q}}{\mathrm{a}}$ the three main divisions births in which two mal-w formations are combined. We have included $\vec{\circ}$ " anencephalus with spina bifida" in the anencephalus group, since 33 of the 34 foetuses were $\vec{\omega}$ stillborn, and anencephalus is the more lethal malformation. "Spina bifida with hydrocephalus", is included with spina bifida; we were influenced w by the fact that spina bifida is the more reliable ${ }^{+}$ diagnosis, although in this case the proportion of $\overrightarrow{\mathrm{C}}$ stillborn infants with the combined lesions is almost ${ }_{\rho}^{\omega}$ mid-way between the proportions in each of the two component groups.

During the eight years 1940 to 1947 , the totalo number of births in Birmingham was 158,307 , of which 4,290 were stillbirths and 154,017 live births.. $\mathbb{~}$ From these figures, the numbers in Table V have $\overrightarrow{0}$ been converted into rates which are shown in ${ }_{0}$ Table VI. The total incidence of fatal malforme tions of the nervous system in Birmingham (0.58 550

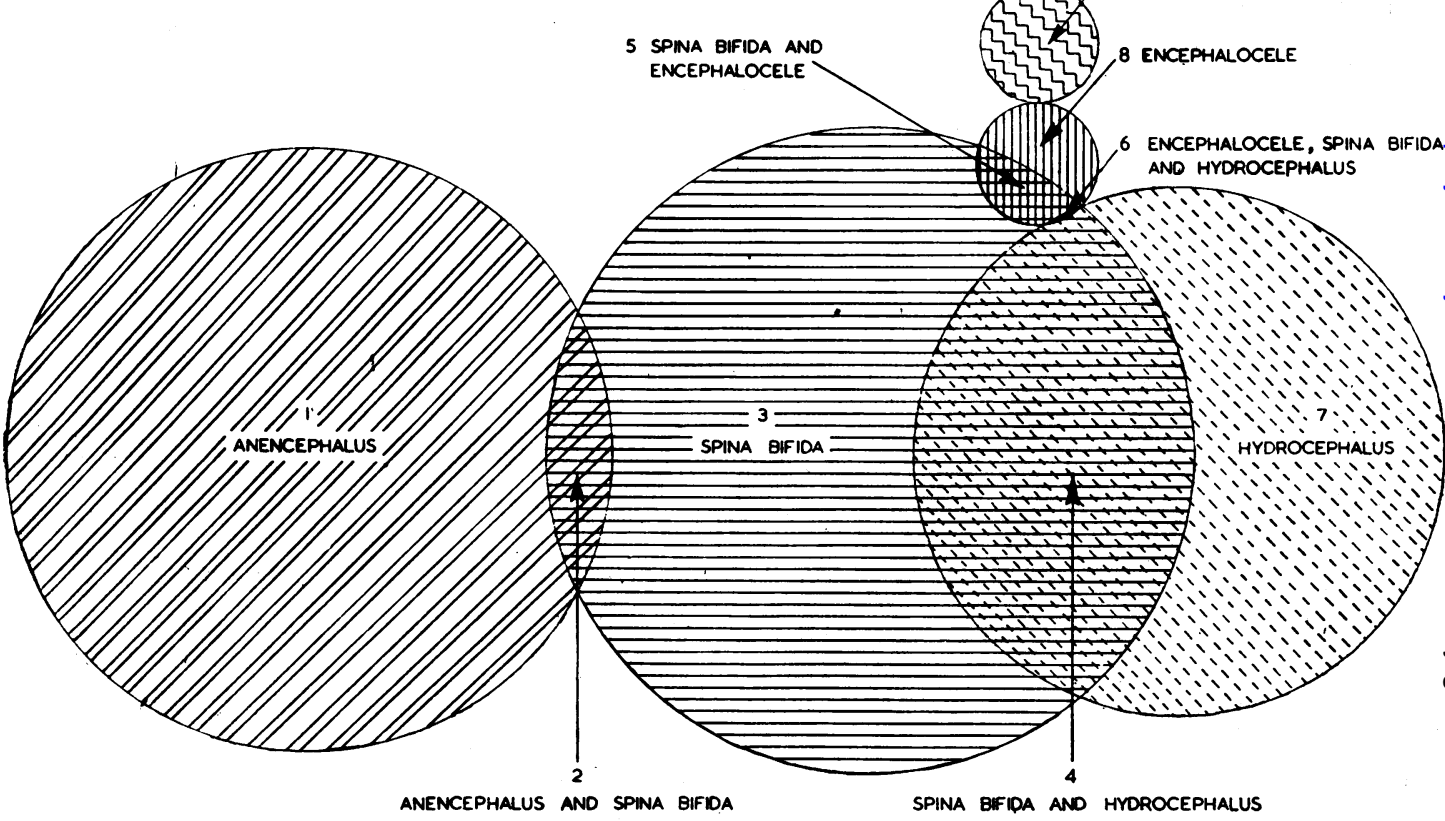

FIG. 1.-Combinations of central nervous malformations of different types. 


\section{MALFORMATIONS OF THE CENTRAL NERVOUS SYSTEM-I}

TABLE VII

Numbers of Central Nervous Malformations of DifFerent TyPES FOUND IN 930 consecutive CASES IN BiRMINGHAM (1940-1947)

\begin{tabular}{l|c|c}
\hline $\begin{array}{c}\text { Type of } \\
\text { Malformation }\end{array}$ & Number & $\begin{array}{c}\text { Incidence (per } \\
1,000 \text { Births, } \\
\text { Live and Stillborn) }\end{array}$ \\
\hline Anencephalus .. & 366 & $2 \cdot 312$ \\
\hline Spina bifida $\ldots$ & 423 & $2 \cdot 672$ \\
\hline Hydrocephalus .. & 280 & $1 \cdot 769$ \\
\hline Encephalocele .. & 16 & $0 \cdot 101$ \\
\hline Others . . & 14 & $0 \cdot 088$ \\
\hline Total $\ldots$ & 1,099 & $6 \cdot 942$ \\
\hline
\end{tabular}

per cent.) is slightly below the Scottish figure ( 0.68 per cent.) for 1941 to 1945 , as is the stillbirth rate of $2 \cdot 192$ due to anencephalus compared with the Scottish rate of $2 \cdot 549$ for the years 1939 to 1945 . As already indicated, these data are not strictly comparable, although the error in the figures here compared is probably not great.

Co-EXISTENCE OF Nervous MALFORMATIONS.-The comparatively high incidence of two distinct malformations of the central nervous system in one individual is not explained by their chance association. The total number of central nervous malformations of different types in the $\mathbf{9 3 0}$ affected individuals in the series are given in Table VII in which two malformations in the same foetus are entered separately. If the co-existence of malformations were entirely fortuitous, the incidence of the combination would be the product of their frequencies,

\section{TABLE VIII}

Expected and Observed Numbers of Various Combinations of Central Nervous Malformations

\begin{tabular}{llll|c|c|c}
\hline \multicolumn{1}{c|}{ Combination } & & & $\begin{array}{c}\text { Expected Ffequency } \\
\text { per 1,000 Births }\end{array}$ & $\begin{array}{c}\text { Expected Number } \\
\text { in Universe of } \\
158,307 \text { Births }\end{array}$ & $\begin{array}{c}\text { Observed Number } \\
\text { in Universe of } \\
158,307 \text { Births }\end{array}$ \\
\hline Anencephalus and spina bifida &. &. &. & 0.006178 & 0.978 & 34 \\
\hline Hydrocephalus and spina bifida &. &. &. & 0.004727 & 0.748 & 129 \\
\hline Encephalocele and spina bifida &. &. &. & 0.000270 & 0.043 & 4 \\
\hline Hydrocephalus, encephalocele, and spina bifida &. & 0.00000048 & 0.00008 & 1 \\
\hline
\end{tabular}

TABLE IX

Other Deformtties Co-existing with Malformations of the Central Nervous System

\begin{tabular}{|c|c|c|c|c|c|c|c|}
\hline \multirow{2}{*}{\multicolumn{3}{|c|}{ Co-existing Deformity }} & \multicolumn{5}{|c|}{ Type of Central Nervous Malformation (Simplified Classification) } \\
\hline & & & Anencephalus & Spina bifida & Hydrocephalus & Others & All \\
\hline $\begin{array}{l}\text { Exomphalos } \\
\text { Congenital heart } \\
\text { Hare-lip and /or cleft palate } \\
\text { Malformation of cord } \\
\text { Talipes } \\
\text { Other skeletal deformities } \\
\text { Other malformations } \\
\text { Multiple malformations }\end{array}$ & $\begin{array}{l}\because \\
\because \\
\because \\
\because \\
\because \\
\because \\
.\end{array}$ & $\begin{array}{l}. . \\
\cdots \\
\cdots \\
\cdots \\
\cdots \\
. \\
. \\
.\end{array}$ & $\begin{array}{c}\frac{9}{7} \\
-1 \\
1 \\
2 \\
1 \\
1\end{array}$ & $\begin{array}{r}2 \\
2 \\
3 \\
1 \\
26 \\
8 \\
2 \\
-\end{array}$ & $\begin{array}{c}\overline{3} \\
\overline{-} \\
2 \\
4 \\
2 \\
5\end{array}$ & $\begin{array}{l}\frac{1}{1} \\
\frac{1}{1} \\
\frac{1}{3}\end{array}$ & $\begin{array}{r}12 \\
5 \\
4 \\
2 \\
29 \\
15 \\
5 \\
9\end{array}$ \\
\hline Total number of deformities & .. & . & 15 & 44 & 16 & 6 & 81 \\
\hline $\begin{array}{l}\text { Number of individuals exhib } \\
\text { Total number in group } \\
\text { Percentage of individuals } \\
\text { deformity } \\
\begin{array}{l}\text {. . } \\
\text {.. }\end{array}\end{array}$ & $\begin{array}{l}\text { th } \\
. .\end{array}$ & $\begin{array}{l}\text { existing } \\
\text { e }\end{array}$ & $\begin{array}{r}14 \\
366 \\
3 \cdot 8\end{array}$ & $\begin{array}{r}42 \\
389 \\
10 \cdot 8\end{array}$ & $\begin{array}{c}16 \\
150 \\
10 \cdot 7\end{array}$ & $\begin{array}{c}5 \\
25 \\
20 \cdot 0\end{array}$ & $\begin{array}{r}77 \\
930 \\
8 \cdot 3\end{array}$ \\
\hline
\end{tabular}


TABLE X

Sex Incidence of Malformations of the Central Nervous System in Birmingham (1940-1947)

\begin{tabular}{|c|c|c|c|c|c|c|}
\hline \multirow{2}{*}{ Type of Malformation } & \multicolumn{3}{|c|}{ Number of } & \multirow{2}{*}{$\begin{array}{c}\text { Sex Ratio } \\
\text { (Number of } \\
\text { Males per } \\
1,000 \\
\text { Females) }\end{array}$} & \multirow{2}{*}{$\begin{array}{c}\text { Percentage } \\
\text { of Males }\end{array}$} & \multirow{2}{*}{$\begin{array}{l}\text { Discrepancy } \\
\text { between this } \\
\text { percentage and } \\
50 \% \text { (which } \\
\text { corresponds to a } \\
\text { Sex Ratio of } \\
\text { Unity) }\end{array}$} \\
\hline & Males & Females & Both & & & \\
\hline 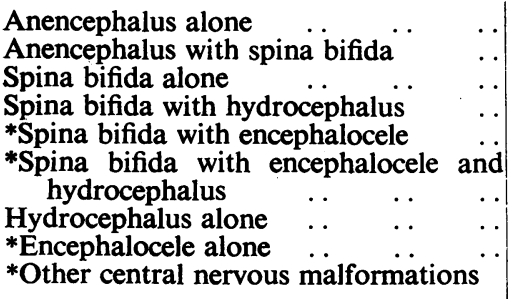 & $\begin{array}{r}109 \\
8 \\
108 \\
59 \\
-\end{array}$ & $\begin{array}{r}223 \\
26 \\
146 \\
70 \\
4 \\
1 \\
85 \\
5 \\
7\end{array}$ & $\begin{array}{r}332 \\
34 \\
254 \\
129 \\
4 \\
1 \\
1 \\
150 \\
11 \\
14\end{array}$ & $\begin{array}{l}489 \\
308 \\
740 \\
843 \\
- \\
- \\
- \\
-\end{array}$ & $\begin{array}{l}32 \cdot 83 \\
23 \cdot 53 \\
42 \cdot 52 \\
45 \cdot 74 \\
- \\
- \\
43 \cdot 33 \\
-\end{array}$ & $\begin{array}{l}17 \cdot 17 \pm 2 \cdot 58 \\
26 \cdot 47 \pm 7 \cdot 27 \\
7 \cdot 48 \pm 3 \cdot 10 \\
4 \cdot 26 \pm 4 \cdot 39 \\
- \\
6 \cdot 67 \pm 4 \cdot 04 \\
-\end{array}$ \\
\hline Total & 362 & 567 & 929 & 638 & $38 \cdot 97$ & $11 \cdot 03 \pm 1 \cdot 60$ \\
\hline
\end{tabular}

TABLE XI

Sex Incidence of Malformations of the. Central Nervous System in Birmingham (1940-1947)

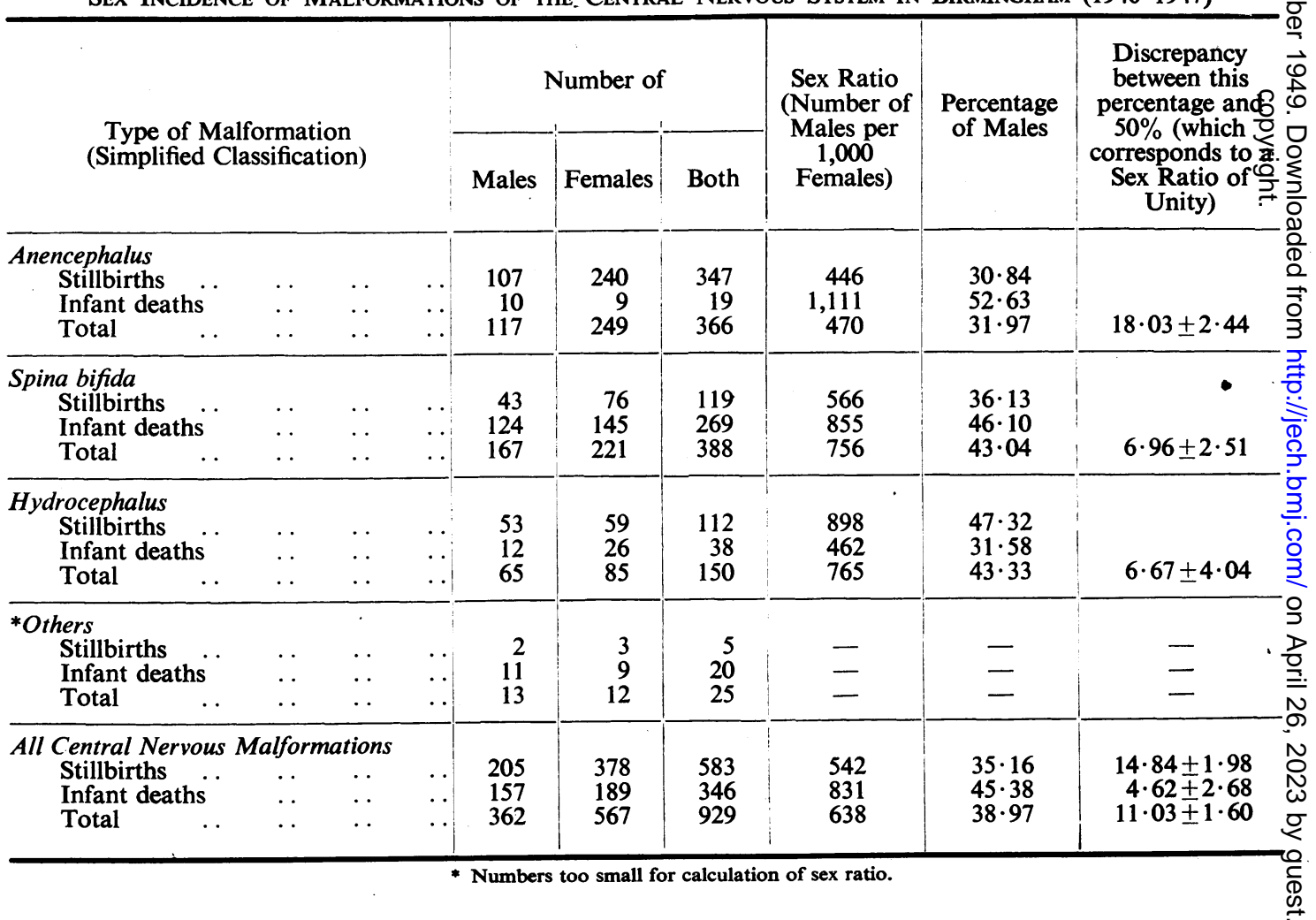

and Table VIII (previous page) compares the expected and observed numbers. The considerable differences between these two sets of figures indicate' either that the presence of one malformation predisposes to the formation of another, or that 20 common factor is concerned in their aetiology. 
TABLE XII

Sex Incidence of Malformations of the Central Nervous System in Scotland (1939-1945)

\begin{tabular}{|c|c|c|c|c|c|c|c|c|c|}
\hline \multirow{2}{*}{\multicolumn{4}{|c|}{ Type of Malformation }} & \multicolumn{3}{|c|}{ Number of } & \multirow{2}{*}{$\begin{array}{c}\text { Sex Ratio } \\
\text { (Number of } \\
\text { Males per } \\
1,000 \\
\text { Females) }\end{array}$} & \multirow{2}{*}{$\begin{array}{l}\text { Percentage } \\
\text { of Males }\end{array}$} & \multirow{2}{*}{$\begin{array}{l}\text { Discrepancy } \\
\text { between this } \\
\text { percentage and } \\
50 \% \text { (which } \\
\text { corresponds to a } \\
\text { Sex Ratio of } \\
\text { Unity) }\end{array}$} \\
\hline & & & & Males & Females & Both & & & \\
\hline $\begin{array}{l}\text { Anencephalus } \\
\text { Stillbirths only }\end{array}$ & .. & . & . & 446 & 1,222 & 1,668 & 365 & $26 \cdot 74$ & $23 \cdot 26 \pm 1 \cdot 08$ \\
\hline $\begin{array}{l}\text { Spina bifida } \\
\text { Stillbirths } \ldots \\
\text { Infant deaths } \\
\text { Total }\end{array}$ & $\begin{array}{l}\cdots \\
\cdots \\
\cdots\end{array}$ & $\begin{array}{l}. . \\
\cdots \\
\cdots\end{array}$ & $\begin{array}{l}\cdots \\
\cdots \\
\cdots\end{array}$ & $\begin{array}{l}120 \\
534 \\
654\end{array}$ & $\begin{array}{l}182 \\
676 \\
858\end{array}$ & $\begin{array}{r}302 \\
1,210 \\
1,512\end{array}$ & $\begin{array}{l}659 \\
790 \\
762\end{array}$ & $\begin{array}{l}39 \cdot 74 \\
44 \cdot 13 \\
43 \cdot 25\end{array}$ & $\begin{array}{r}10 \cdot 26 \pm 2 \cdot 82 \\
5 \cdot 87 \pm 1 \cdot 43 \\
6 \cdot 75 \pm 1 \cdot 27\end{array}$ \\
\hline $\begin{array}{l}\text { Hydrocephalus } \\
\text { Stillbirths } \\
\text { Infant deaths } \\
\text { Total }\end{array}$ & $\begin{array}{l}. \\
\cdots \\
\cdots\end{array}$ & $\begin{array}{l}. . \\
\cdots \\
\cdots\end{array}$ & $\begin{array}{l}\cdots \\
\cdots \\
\cdots\end{array}$ & $\begin{array}{l}458 \\
231 \\
689\end{array}$ & $\begin{array}{l}428 \\
237 \\
665\end{array}$ & $\begin{array}{r}886 \\
468 \\
1,354\end{array}$ & $\begin{array}{r}1,070 \\
975 \\
1,036\end{array}$ & $\begin{array}{l}51 \cdot 69 \\
49 \cdot 36 \\
50 \cdot 89\end{array}$ & $\begin{array}{r}-1.69 \pm 1.68 \\
0.64 \pm 2.31 \\
-0.89 \pm 1.36\end{array}$ \\
\hline $\begin{array}{l}\text { Total } \\
\text { Stillbirths } \\
\text { Infant deaths } \\
\text { Total }\end{array}$ & $\begin{array}{l}\ldots \\
\cdots \\
\cdots\end{array}$ & $\begin{array}{l}. . \\
\cdots \\
.\end{array}$ & $\begin{array}{l}. . \\
. .\end{array}$ & $\begin{array}{r}1,024 \\
765 \\
1,789\end{array}$ & $\begin{array}{r}1,832 \\
913 \\
2,745\end{array}$ & $\begin{array}{l}2,856 \\
1,678 \\
4,534\end{array}$ & $\begin{array}{l}559 \\
838 \\
652\end{array}$ & $\begin{array}{l}35 \cdot 85 \\
45 \cdot 59 \\
39 \cdot 46\end{array}$ & $\begin{array}{r}14 \cdot 15 \pm 0 \cdot 90 \\
4 \cdot 41 \pm 1 \cdot 21 \\
10 \cdot 54 \pm 0 \cdot 73\end{array}$ \\
\hline
\end{tabular}

Additional Malformations.-Of 930 infants born with one or more central nervous malformations, $77(8 \cdot 3$ per cent.) showed deformities of other organs (Table IX, p. 189). The table illustrates the well-known association between talipes and spina bifida, due presumably to a disturbance of the nervous tracts supplying the lower extremities, and also suggests an association between exomphalos and anencephalus.

SEX RATIO.-The sex incidence of 929 malformations* is given in Table $X$ for all cases, and in Table XI for the three main divisions: anencephalus, spina bifida, hydrocephalus. Except for hydrocephalus, in which our numbers are small, the results are in reasonable agreement with the estimates calculated from Scottish data for the years 1939 to 1945 (see Table XII).

These differences are, of course, well recognized, although no satisfactory explanation is available for them. If equal numbers of both sexes are malformed in the early weeks of gestation, more males must be aborted in the period before the birth is notifiable, and when the sex is often unknown. Certainly the evidence does not suggest that males are less viable than females in the later months, for of the 929 Birmingham malformations, 43.4 per cent. of males and 33.3 per cent. of females were alive at birth. The corresponding figures for spina

\footnotetext{
* In one of the 930 cases, the sex was not given.
}

bifida and hydrocephalus based on the Scottish statistics are given in Table XIIA.

TABLE XIIA

Sex Incidence of Specific Malformations alive at Birth. SCOTLAND (1939-1945)

\begin{tabular}{c|l|c|c}
\hline $\begin{array}{c}\text { Malforma- } \\
\text { tion }\end{array}$ & Sex & $\begin{array}{c}\text { Number of } \\
\text { Cases }\end{array}$ & $\begin{array}{c}\text { Percentage } \\
\text { Live Born }\end{array}$ \\
\hline \multirow{2}{*}{\begin{tabular}{c} 
Spina bifida \\
\cline { 2 - 3 }
\end{tabular}} & Male & 654 & $81 \cdot 7$ \\
\cline { 2 - 4 } $\begin{array}{c}\text { Hydro- } \\
\text { cephalus }\end{array}$ & Female & 858 & $78 \cdot 8$ \\
\cline { 2 - 4 } & Female & 689 & $33 \cdot 5$ \\
\hline
\end{tabular}

The conclusion about the respective viability of male and female malformations would, of course, be affected if different proportions of the two sexes were alive at the end of the first year. In his report on 144 malformations of the central nervous system, Penrose (1946) records 22 male and 24 female malformations which survived the first year. Scottish data for the period 1941-1945 are also relevant (see Table XIIB, overleaf).

SECUlAR TREND.-The annual numbers of malformations of the central nervous system notified in Birmingham (1940-1947) are given in Table XIII (overleaf), with the total numbers of live and still 
TABLE XIIB

Sex Incidence of Specific Malformations Which SURVIVED First Year. SCOTLAND (1939-45)

\begin{tabular}{|c|c|c|c|}
\hline \multirow{2}{*}{$\begin{array}{l}\text { Malforma- } \\
\text { tion }\end{array}$} & \multicolumn{3}{|c|}{ Deaths after the First Year of Life } \\
\hline & Males & Females & Total \\
\hline $\begin{array}{l}\text { Congenital } \\
\text { hydro- } \\
\text { cephalus }\end{array}$ & 43 & 25 & 68 \\
\hline $\begin{array}{l}\text { Spina bifida } \\
\text { and menin- } \\
\text { gocele } \quad .\end{array}$ & 12 & 21 & 33 \\
\hline
\end{tabular}

births for the same years. From these figures the rates exhibited in Table XIV and Fig. 3 have been calculated. Unlike the national rates relevant to all malformations cited in Tables I and II, the Birmingham rates of anencephalus and spina bifida show an unmistakable decline in the eight-year period; the rates of hydrocephalus are fairly constant. Fig. 2 indicates that the incidence of malformations has fallen at a relatively greater rate than the incidence of stillbirths from all causes.

In accounting for this somewhat unexpected result, it is important to consider secular changes in

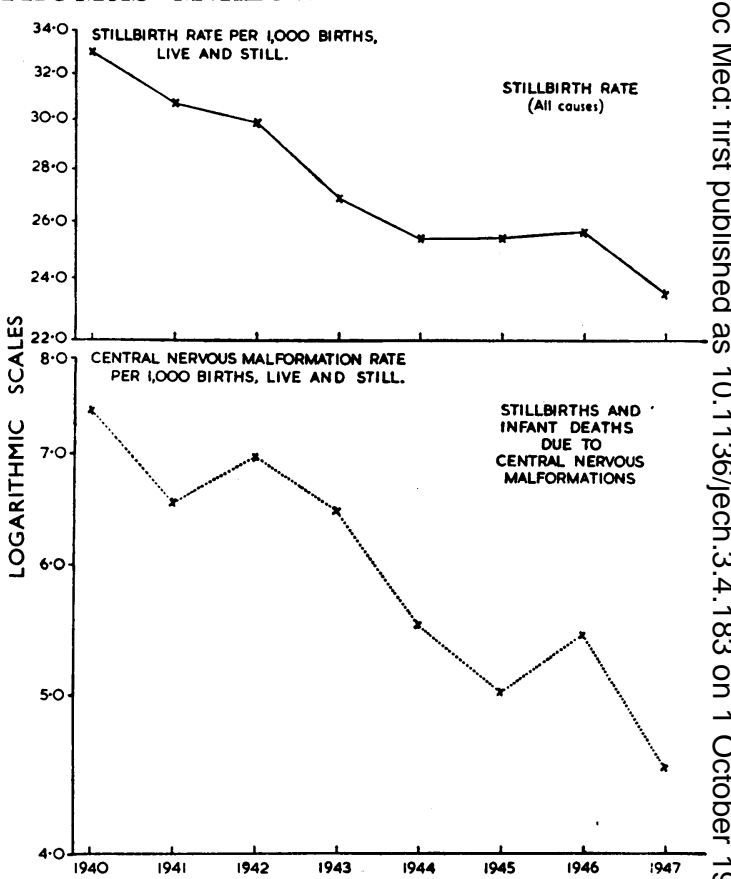

FIG. 2.-Annual rates for stillbirths (all causes) and for central nervous malformations (Birmingham, 1940-47\$.

TABLE XIII

Annual Numbers of Malformations of the Central Nervous System in Birmingham (1940-1947)

\begin{tabular}{|c|c|c|c|c|c|c|c|c|c|c|}
\hline \multirow{2}{*}{$\begin{array}{c}\text { Type of } \\
\text { Malformation }\end{array}$} & \multirow{2}{*}{$\begin{array}{l}\text { Stillbirth or } \\
\text { Infant Death }\end{array}$} & \multicolumn{8}{|c|}{ Year } & \multirow{2}{*}{$\begin{array}{l}\text { Whole } \\
\text { Period }\end{array}$} \\
\hline & & 1940 & 1941 & 1942 & 1943 & 1944 & 1945 & 1946 & 1947 & \\
\hline \multirow[t]{2}{*}{ Anencephalus } & $\begin{array}{l}\text { S.B. } \\
\text { I.D. }\end{array}$ & $\begin{array}{r}43 \\
5\end{array}$ & $\begin{array}{r}37 \\
2\end{array}$ & $\begin{array}{r}47 \\
1\end{array}$ & 53 & $\begin{array}{r}47 \\
1\end{array}$ & $\begin{array}{r}42 \\
3\end{array}$ & $\begin{array}{r}41 \\
1\end{array}$ & $\begin{array}{r}37 \\
6\end{array}$ & $\begin{array}{r}347 \\
19\end{array}$ \\
\hline & Total & 48 & 39 & 48 & 53 & 48 & 45 & 42 & 43 & 366 \\
\hline \multirow[t]{2}{*}{ Spina bifida } & $\begin{array}{l}\text { S.B. } \\
\text { I.D. }\end{array}$ & $\begin{array}{l}23 \\
32\end{array}$ & $\begin{array}{l}13 \\
25\end{array}$ & $\begin{array}{l}12 \\
47\end{array}$ & $\begin{array}{l}14 \\
39\end{array}$ & $\begin{array}{l}17 \\
37\end{array}$ & $\begin{array}{l}10 \\
28\end{array}$ & $\begin{array}{l}17 \\
35\end{array}$ & $\begin{array}{l}14 \\
26\end{array}$ & 120 \\
\hline & Total & 55 & 38 & 59 & 53 & 54 & 38 & 52 & 40 & 389. \\
\hline \multirow[t]{2}{*}{ Hydrocephalus } & $\begin{array}{l}\text { S.B. } \\
\text { I.D. }\end{array}$ & $\begin{array}{r}11 \\
5\end{array}$ & $\begin{array}{r}14 \\
3\end{array}$ & $\begin{array}{r}12 \\
4\end{array}$ & $\begin{array}{r}17 \\
2\end{array}$ & $\begin{array}{r}13 \\
4\end{array}$ & $\begin{array}{l}9 \\
5\end{array}$ & $\begin{array}{r}21 \\
6\end{array}$ & $\begin{array}{r}15 \\
9\end{array}$ & $112 \frac{0}{3}$ \\
\hline & Total & 16 & 17 & 16 & 19 & 17 & 14 & 27 & 24 & 150 \\
\hline \multirow{2}{*}{$\begin{array}{c}\text { Encephalocele and } \\
\text { other Central } \\
\text { Nervous } \\
\text { Malformations }\end{array}$} & $\begin{array}{l}\text { S.B. } \\
\text { I.D. }\end{array}$ & $\overline{3}$ & $\overline{1}$ & $\begin{array}{l}1 \\
3\end{array}$ & $\begin{array}{l}1 \\
3\end{array}$ & $\overline{4}$ & $\overline{2}$ & $\overline{3}$ & $\begin{array}{l}3 \\
1\end{array}$ & \\
\hline & Total & 3 & 1 & 4 & 4 & 4 & 2 & 3 & 4 & \\
\hline \multirow{2}{*}{$\begin{array}{l}\text { All Central } \\
\text { Nervous } \\
\text { Malformations }\end{array}$} & $\begin{array}{l}\text { S.B. } \\
\text { I.D. }\end{array}$ & $\begin{array}{l}77 \\
45\end{array}$ & $\begin{array}{l}64 \\
31\end{array}$ & $\begin{array}{l}72 \\
55\end{array}$ & $\begin{array}{l}85 \\
44\end{array}$ & $\begin{array}{l}77 \\
46\end{array}$ & $\begin{array}{l}61 \\
38\end{array}$ & $\begin{array}{l}79 \\
45\end{array}$ & $\begin{array}{l}69 \\
42\end{array}$ & $\begin{array}{l}584 \\
346\end{array}$ \\
\hline & Total & 122 & 95 & 127 & 129 & 123 & 99 & 124 & 111 & 930 \\
\hline \multicolumn{2}{|c|}{$\begin{array}{l}\text { Total Live Births } \\
\text { Total Stillbirths (all Causes) }\end{array}$} & $\begin{array}{r}15,882 \\
542\end{array}$ & $\begin{array}{r}14,063 \\
445\end{array}$ & $\begin{array}{r}17,657 \\
543\end{array}$ & $\begin{array}{r}19,376 \\
535\end{array}$ & $\begin{array}{r}21,720 \\
565\end{array}$ & $\begin{array}{r}19,185 \\
500\end{array}$ & $\begin{array}{r}22,134 \\
583\end{array}$ & $\begin{array}{r}24,000 \\
577\end{array}$ & $\begin{array}{r}154,017 \\
4,290\end{array}$ \\
\hline \multicolumn{2}{|c|}{ All Births, Live and Still } & 16,424 & 14,508 & 18,200 & 19,911 & 22,285 & 19,685 & 22,717 & 24,577 & 158,30 \\
\hline
\end{tabular}


TABLE XIV

Annual Incidence of Malformations of the Central Nervous System in Birmingham, 1940-1947 (Rate per 1,000 TOTAL BIRTHS)

\begin{tabular}{|c|c|c|c|c|c|c|c|c|c|c|}
\hline \multirow{2}{*}{\multicolumn{2}{|c|}{ Type of Malformation }} & \multicolumn{8}{|c|}{ Year } & \multirow{2}{*}{$\begin{array}{l}\text { Whole } \\
\text { Period }\end{array}$} \\
\hline & & 1940 & 1941 & 1942 & 1943 & 1944 & 1945 & 1946 & 1947 & \\
\hline $\begin{array}{l}\text { Anencephalus } \\
\text { Spina bifida ... } \\
\text { Hydrocephalus } \\
\text { Others }\end{array}$ & $\begin{array}{l}. \\
. \\
.\end{array}$ & $\begin{array}{l}2 \cdot 923 \\
3 \cdot 349 \\
0 \cdot 974 \\
0 \cdot 183\end{array}$ & $\begin{array}{l}2 \cdot 688 \\
2 \cdot 619 \\
1 \cdot 172 \\
0.069\end{array}$ & $\begin{array}{l}2 \cdot 637 \\
3 \cdot 242 \\
0 \cdot 879 \\
0 \cdot 220\end{array}$ & $\begin{array}{l}2 \cdot 662 \\
2 \cdot 662 \\
0 \cdot 954 \\
0 \cdot 201\end{array}$ & $\begin{array}{l}2 \cdot 154 \\
2 \cdot 423 \\
0 \cdot 763 \\
0 \cdot 179\end{array}$ & $\begin{array}{l}2 \cdot 286 \\
1.930 \\
0 \cdot 711 \\
0 \cdot 102\end{array}$ & $\begin{array}{l}1 \cdot 849 \\
2 \cdot 289 \\
1 \cdot 189 \\
0 \cdot 132\end{array}$ & $\begin{array}{l}1 \cdot 750 \\
1 \cdot 628 \\
0.977 \\
0 \cdot 163\end{array}$ & $\begin{array}{l}2 \cdot 312 \\
2 \cdot 457 \\
0.948 \\
0 \cdot 158\end{array}$ \\
\hline \multirow[t]{2}{*}{$\begin{array}{l}\text { All Central } \\
\text { Nervous } \\
\text { Malformations }\end{array}$} & $\begin{array}{l}\text { Stillbirths } \\
\text { Infant } \\
\text { Deaths }\end{array}$ & $\begin{array}{l}4 \cdot 688 \\
2 \cdot 740\end{array}$ & $\begin{array}{l}4 \cdot 411 \\
2 \cdot 137\end{array}$ & $3 \cdot 956$ & $\begin{array}{l}4 \cdot 269 \\
2 \cdot 210\end{array}$ & $\begin{array}{l}3 \cdot 455 \\
2 \cdot 064\end{array}$ & $\begin{array}{l}3.099 \\
1.930\end{array}$ & $\begin{array}{l}3 \cdot 477 \\
1 \cdot 981\end{array}$ & $\begin{array}{l}2 \cdot 807 \\
1 \cdot 709\end{array}$ & $\begin{array}{l}3 \cdot 689 \\
2 \cdot 186\end{array}$ \\
\hline & Total & $7 \cdot 428$ & $6 \cdot 548$ & $6 \cdot 978$ & $6 \cdot 479$ & $5 \cdot 519$ & $5 \cdot 029$ & $5 \cdot 458$ & $4 \cdot 516$ & $5 \cdot 875$ \\
\hline \multicolumn{2}{|c|}{ Stillbirth Rate (all Causes) } & $33 \cdot 00$ & $30 \cdot 67$ & $29 \cdot 84$ & $26 \cdot 87$ & $25 \cdot 35$ & $25 \cdot 40$ & $25 \cdot 66$ & $23 \cdot 48$ & $27 \cdot 10$ \\
\hline
\end{tabular}

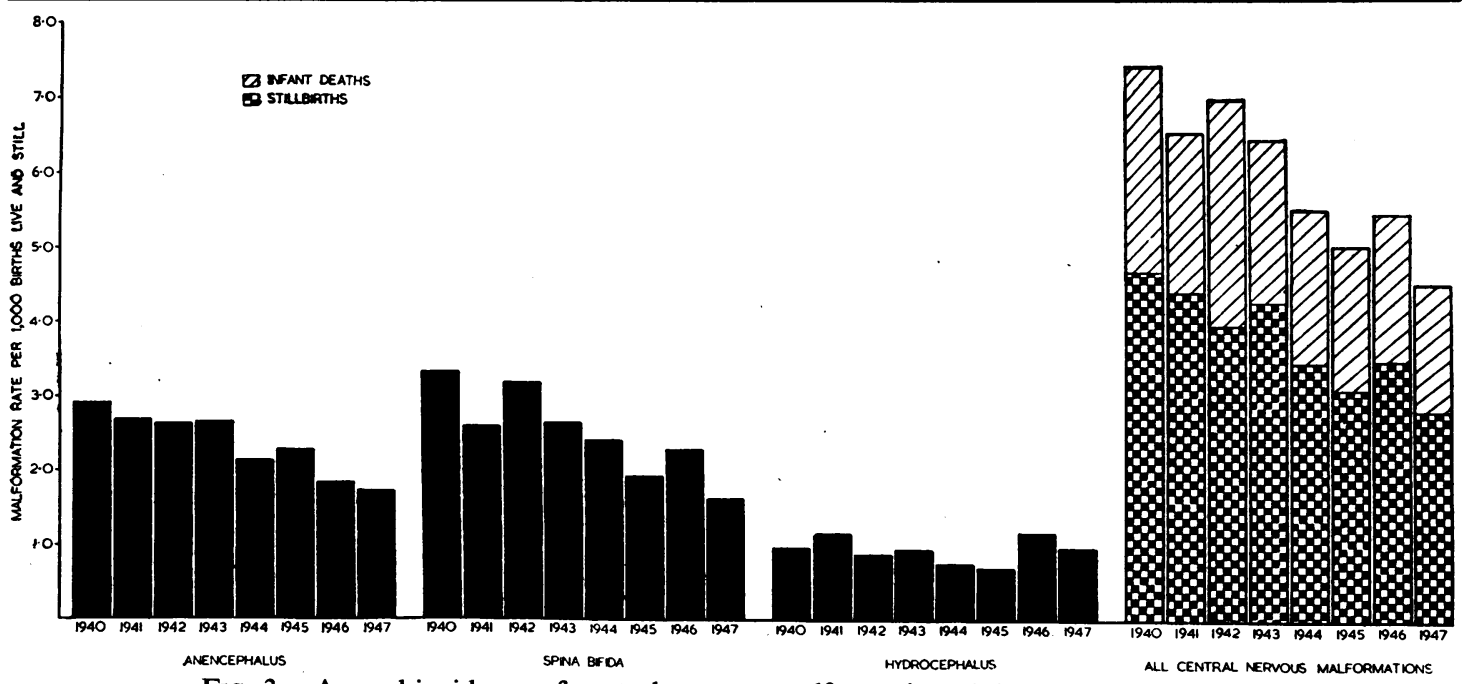

Fig. 3.-Annual incidence of central nervous malformations (Birmingham, 1940-47).

parity, since we show below that the risk of a central nervous malformation is relatively greater at the first birth rank and above the sixth. Unfortunately, information on parity is not available for all Birmingham births of these years, and although the data were recorded by field enquiry for a control group selected from all births, the fact that the percentage of women not interviewed varied from year to year considerably reduces its value. We have therefore estimated the proportions of malformations of the central nervous system notified in each year (1941 to 1947)* which are in the first birth rank or above the sixth (Table XV, overleaf). Fig. 4 (overleaf) shows that, with the exception of the year 1944, the proportions in the parities where the risks are greatest declined, as did the central nervous

\footnotetext{
- Data for 1940 were incomplete.
}

malformation rate. We may interpret these observations conservatively by concluding that if the risk at different birth ranks was relatively constant, the observed reduction in the malformation rate could be explained by the changes in the parity of the mothers, and may not indicate a true reduction of the risk in the later years.

\section{The Malformation and Control Groups COMPARED $\dagger$}

The statistics so far quoted for 930 consecutive malformations of the nervous system were available in central records, and are in consequence free from sampling errors. As indicated in the introduction, additional information in respect of the malformations, and of a control group of normal births, was

\footnotetext{
+ Data from field enquiry.
} 
TABLE XV

annual Proportions of Central Nervous Malformations at the First or above the Sixth Birth Ranks in BiRMINGHAM (1941-1947)

\begin{tabular}{|c|c|c|c|c|c|c|c|c|}
\hline \multirow[b]{2}{*}{ 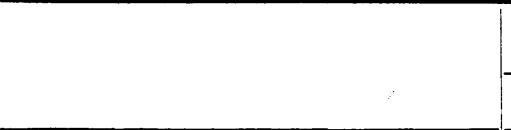 } & \multicolumn{7}{|c|}{ Year } & \multirow{2}{*}{$\begin{array}{l}\text { Whole } \\
\text { Period }\end{array}$} \\
\hline & 1941 & 1942 & 1943 & 1944 & 1945 & 1946 & 1947 & \\
\hline Total Malformations .. & 95 & 127 & 129 & 123 & 99 & 124 & 111 & 808 \\
\hline $\begin{array}{l}\text { Malformations of unknown Birth Rank } \\
\text { Malformations of known Birth Rank .. }\end{array}$ & $\begin{array}{r}1 \\
94\end{array}$ & $\begin{array}{r}2 \\
125\end{array}$ & $\begin{array}{r}1 \\
128\end{array}$ & $\begin{array}{r}4 \\
119\end{array}$ & $\overline{99}$ & $\overline{124}$ & $\overline{111}$ & $\begin{array}{r}8 \\
800\end{array}$ \\
\hline $\begin{array}{l}\text { Number of Birth Rank } 1 \\
\text { Number of Birth Rank } 7 \text { and over }\end{array}$ & $\begin{array}{r}50 \\
5\end{array}$ & $\begin{array}{l}69 \\
11\end{array}$ & $\begin{array}{r}56 \\
7\end{array}$ & $\begin{array}{r}58 \\
5\end{array}$ & $\begin{array}{r}40 \\
2\end{array}$ & $\begin{array}{r}53 \\
7\end{array}$ & $\begin{array}{r}44 \\
4\end{array}$ & $\begin{array}{r}370 \\
41\end{array}$ \\
\hline Total of Birth Ranks 1 and 7+ & 55 & 80 & 63 & 63 & 42 & 60 & 48 & 411 \\
\hline $\begin{array}{c}\text { Percentage of Malformations of Birth } \\
\text { Ranks } 1 \text { and } 7+\ldots\end{array}$ & $58 \cdot 5$ & $64 \cdot 0$ & $49 \cdot 2$ & $52 \cdot 9$ & $42 \cdot 4$ & $48 \cdot 4$ & $43 \cdot 2$ & $51 \cdot 4$ \\
\hline
\end{tabular}

TABLE XVI

Particulars of Control Series Selected from Registers of live Births and Stillbirths in Birmingham $(1940-1947)$

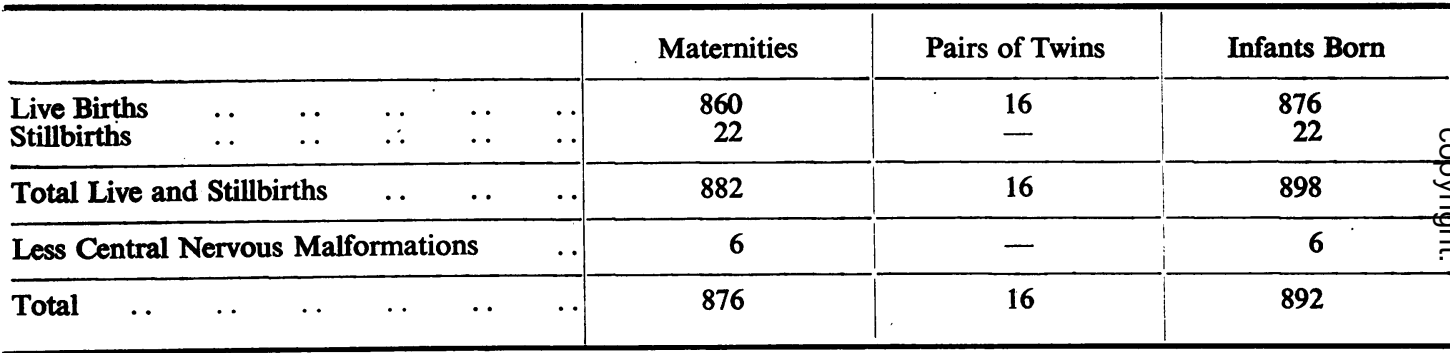

TABLE XVII

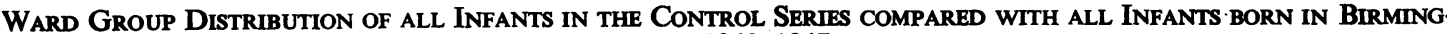
HAM (1940-1947).

\begin{tabular}{c|c|c|c|c|}
\hline \multirow{2}{*}{ Ward Group } & \multicolumn{2}{|c|}{ Infants in Control Series } & \multicolumn{2}{c|}{ All Infants born in City } \\
\cline { 2 - 5 } & Number in Group & Percentage in Group & Number in Group & Percentage in Group \\
\hline I & 322 & $35 \cdot 86$ & 56,669 & $35 \cdot 80$ \\
II & 397 & $44 \cdot 21$ & 72,006 & $45 \cdot 48$ \\
Not located & 179 & $19 \cdot 93$ & 29,583 & $18 \cdot 69$ \\
0 & - & - & 49 & 0.03 \\
\hline Total & 898 & 100 & 158,307 & 100 \\
\hline
\end{tabular}

obtained in all cases where the mother could be interviewed, and we now examine the validity of the samples on which the fuller record was completed. The selection of every two-hundredth name in the register of live and stillbirths for the years 1940-1947 gave a control group of 898 births, divided in Table XVI into live and stillborn, and single and multiple births. This sample is compared with all births in the city for the same years and shows reasonable agreement in respect of ward group* $N$ (Table XVII), year of birth (Table XVIII, opposite), స్ట and season of birth (Table XIX, p. 196). Two o adjustments are necessary and when made in Table XVI give 876 mothers in the control group for comparison with 930 in the malformation $\stackrel{?}{?}$ series.

- For discussion of the division of Birmingham city wards into three social groups, see Appendix A. 


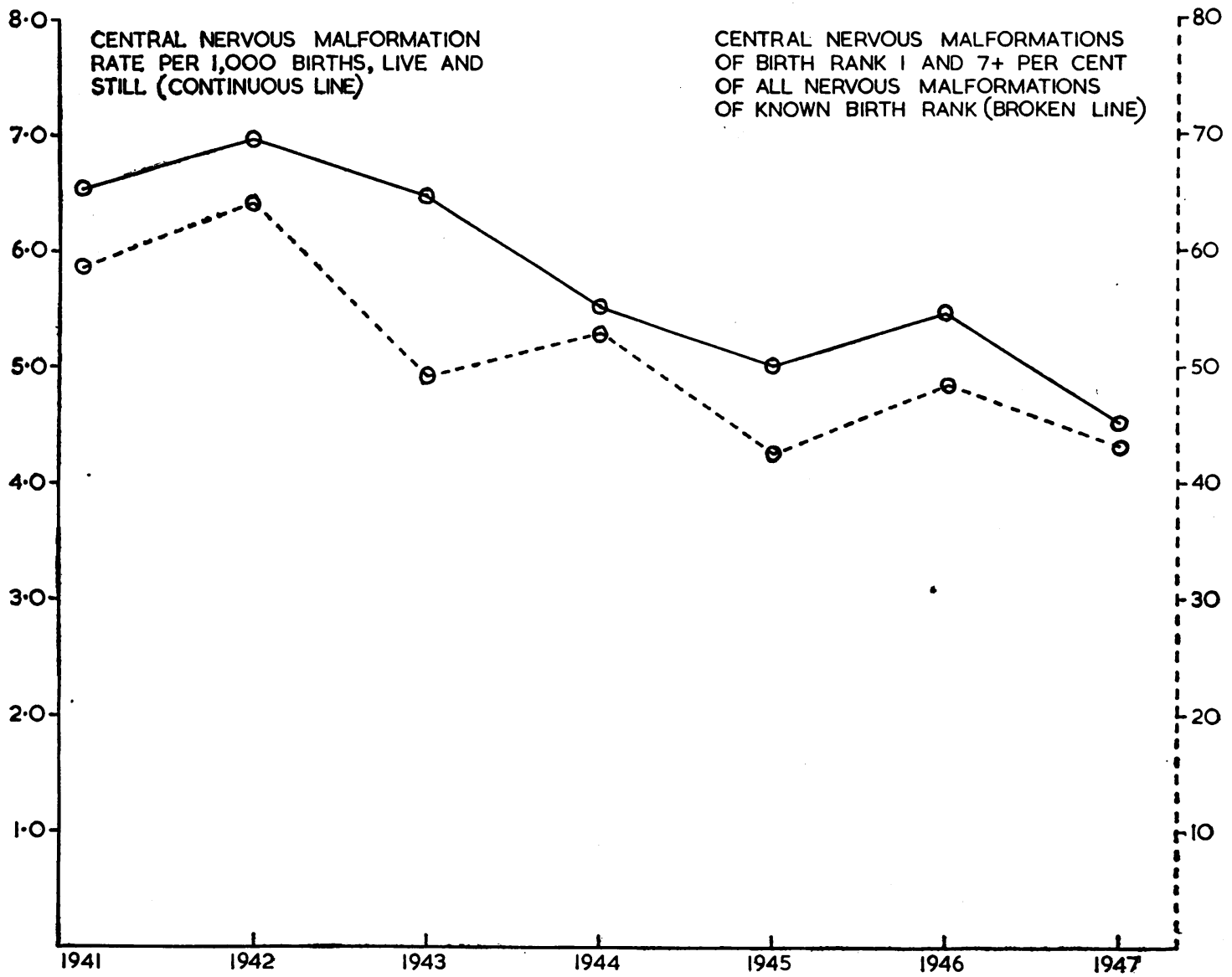

Fig. 4.-Central nervous malformations: annual rates and proportions at birth ranks 1 and $7+$ (Birmingham, 1940-47).

TABLE XVIII

AnNual Distribution of all INfaNTS in the Control Series compared with all INfaNTS born in Birmingham $(1940-1947)$

\begin{tabular}{c|c|c|c|c}
\hline \multirow{2}{*}{ Year } & \multicolumn{2}{|c|}{ Infants in Control Series } & \multicolumn{2}{c}{ All Infants born in City } \\
\cline { 2 - 5 } & Number & Percentage & Number & Percentage \\
\hline 1940 & 99 & $11 \cdot 02$ & 16,424 & $10 \cdot 37$ \\
1941 & 94 & $10 \cdot 47$ & 14,508 & $9 \cdot 16$ \\
1942 & 105 & $11 \cdot 69$ & 18,200 & $11 \cdot 50$ \\
1943 & 113 & $12 \cdot 58$ & 19,911 & $12 \cdot 58$ \\
1944 & 129 & $12 \cdot 25$ & 22,285 & $14 \cdot 08$ \\
1945 & 110 & $12 \cdot 92$ & 19,685 & $12 \cdot 43$ \\
1946 & 116 & $14 \cdot 70$ & 24,717 & $14 \cdot 35$ \\
1947 & 132 & 100 & 2,577 & $15 \cdot 52$ \\
\hline Total & 898 & & 158,307 & $99 \cdot 99$ \\
\hline
\end{tabular}


TABLE XIX

QUARTERLY Distribution OF ALL INFANTS IN THE CONTROL SERIES COMPARED WITH ALL INFANTS BORN IN BIRMINGHAM (1940-1947)

\begin{tabular}{|c|c|c|c|c|}
\hline \multirow{2}{*}{ Quarter } & \multicolumn{2}{|c|}{ Infants in Control Series } & \multicolumn{2}{|c|}{ All Infants born in City } \\
\hline & Number & Percentage & Number & Percentage \\
\hline $\begin{array}{l}\text { January-March } \\
\text { April-June } \ldots \\
\text { July-September } \\
\text { October-December }\end{array}$ & $\begin{array}{l}215 \\
231 \\
228 \\
224\end{array}$ & $\begin{array}{l}23 \cdot 94 \\
25 \cdot 72 \\
25 \cdot 39 \\
24 \cdot 94\end{array}$ & $\begin{array}{l}39,383 \\
41,036 \\
39,017 \\
38,871\end{array}$ & $\begin{array}{l}24 \cdot 88 \\
25 \cdot 92 \\
24 \cdot 65 \\
24 \cdot 55\end{array}$ \\
\hline Total .. & 898 & $99 \cdot 99$ & 158,307 & 100 \\
\hline
\end{tabular}

TABLE XX

Result of Field Survey of Mothers of Malformations and Controls

\begin{tabular}{|c|c|c|c|c|}
\hline \multirow{2}{*}{ Result } & \multicolumn{2}{|c|}{ Malformations } & \multicolumn{2}{|c|}{ Controls } \\
\hline & Number & Percentage & Number & Percentage \\
\hline $\begin{array}{l}\text { Not traced ... } \\
\text { Left Birmingham } \\
\text { Information refused } \\
\text { Died .. } \\
\text { Mental defective } \\
\text { Information unreliable }\end{array}$ & $\begin{array}{r}91 \\
57 \\
17 \\
8 \\
1 \\
1\end{array}$ & $\begin{array}{l}9 \cdot 78 \\
6 \cdot 13 \\
1 \cdot 83 \\
0 \cdot 86 \\
0 \cdot 11 \\
0 \cdot 11\end{array}$ & $\begin{array}{r}63 \\
55 \\
11 \\
4 \\
1 \\
-\end{array}$ & $\begin{array}{r}7 \cdot 19 \\
6 \cdot 28 \\
1 \cdot 26 \\
0 \cdot 46 \\
0 \cdot 11 \\
-\end{array}$ \\
\hline Not interviewed & 175 & $18 \cdot 82 \pm 1 \cdot 28$ & 134 & $15 \cdot 30 \pm 1 \cdot 22$ \\
\hline 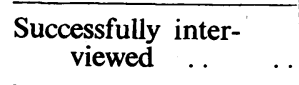 & 755 & $81 \cdot 18$ & 742 & $84 \cdot 70$ \\
\hline Total abstracted & 930 & 100 & 876 & 100 \\
\hline
\end{tabular}

TABLE XXI (see also Fig. 5)

Percentage of Malformations and Controls Interviewed in each Year and Ward Group

\begin{tabular}{|c|c|c|c|c|c|c|c|c|c|c|c|}
\hline & Ward Group & & 1940 & 1941 & 1942 & 1943 & 1944 & 1945 & 1946 & 1947 & Total \\
\hline \multirow{2}{*}{ I } & Malformations & & 48 & 75 & 79 & 75 & 81 & 74 & 86 & 92 & $76 \cdot 4$ \\
\hline & Controls $\quad \ldots$ & 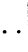 & 62 & 81 & 91 & 84 & 93 & 86 & 75 & 93 & $83 \cdot 5$ \\
\hline \multirow{2}{*}{ II } & Malformations & & 80 & 86 & 84 & 85 & 81 & 86 & 89 & 93 & $85 \cdot 3$ \\
\hline & Controls & & 84 & 86 & 84 & 85 & 85 & 81 & 94 & 96 & $87 \cdot 1$ \\
\hline \multirow{2}{*}{ III } & Malformations & & 68 & 67 & 77 & 82 & 87 & 71 & 93 & 100 & $80 \cdot 8$ \\
\hline & Controls & & 89 & 65 & 71 & 83 & 75 & 70 & 96 & 100 & $81 \cdot 4$ \\
\hline \multirow{2}{*}{ All } & Malformations & & 65 & 79 & 81 & 81 & 82 & 79 & 89 & 94 & $81 \cdot 2$ \\
\hline & Controls & & 76 & 79 & 84 & 84 & 85 & 81 & 88 & 95 & $84 \cdot 7$ \\
\hline
\end{tabular}

(1) The malformations are compared with births not resulting in a central nervous malformation (not with all births); thus six malformations are excluded.

(2) The analysis is based on the number of maternities, and not on the number of births.
Successful interviews were completed in fewer $\stackrel{\circ}{C}$ malformations (81 per cent.) than controls (85 per $\stackrel{\varrho}{\Phi}$ cent.), a difference unlikely to be due to chance (Table XX). The data given by year and ward group in Table XXI (and Fig. 5, opposite), 

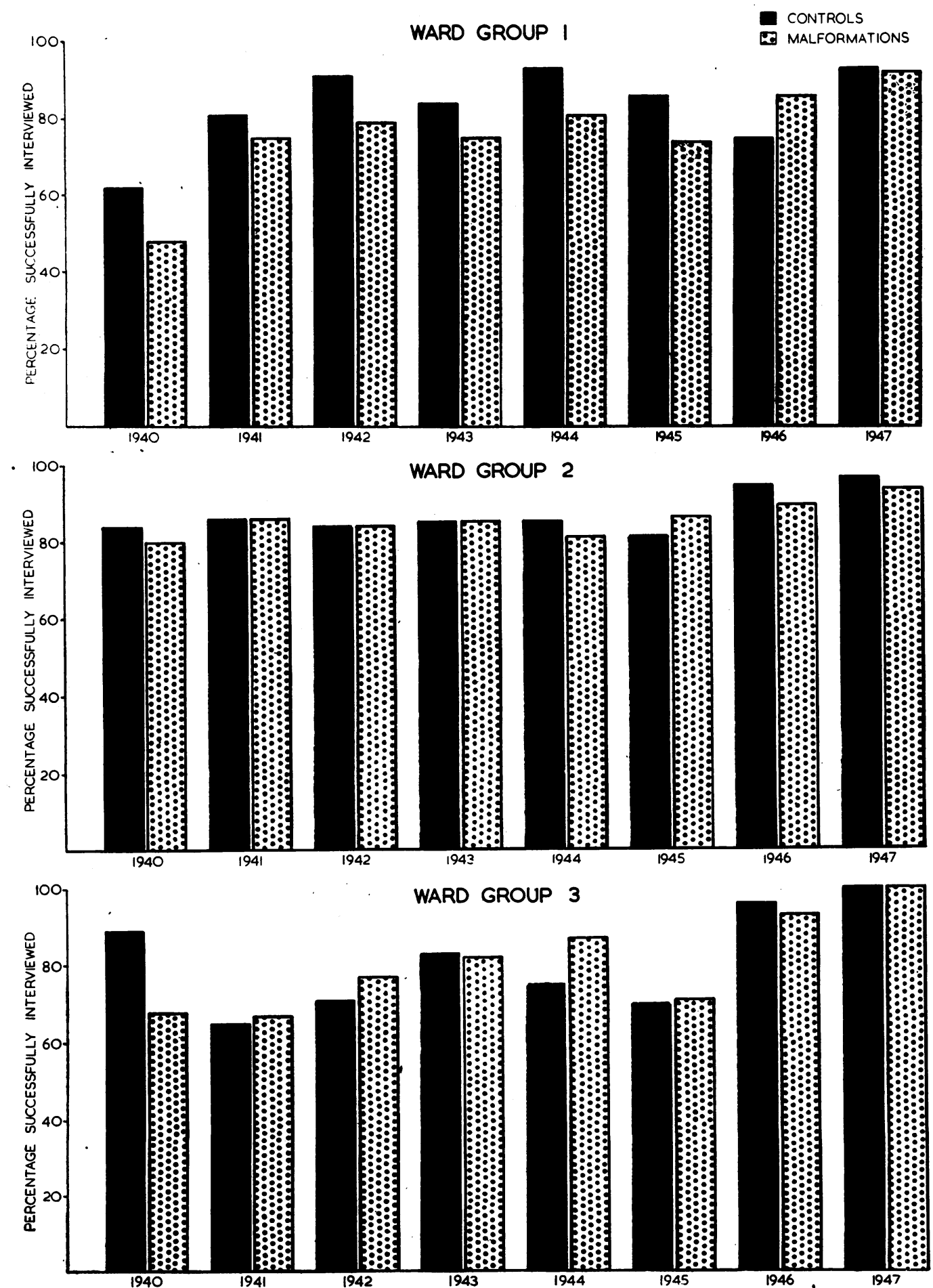

FIG. 5.-Percentage of malformations and controls interviewed in each year and ward group (see also Table XXI). 
TABLE XXII (see also Fig. 6)

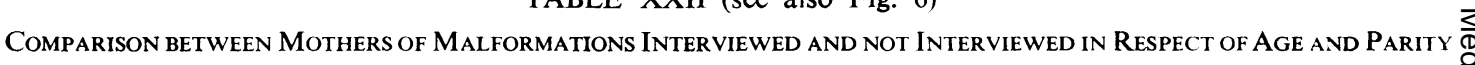

\begin{tabular}{|c|c|c|c|c|}
\hline & \multicolumn{2}{|c|}{ Interviewed } & \multicolumn{2}{|c|}{ Not Interviewed } \\
\hline & Number & Percentage & Number & Percentage \\
\hline 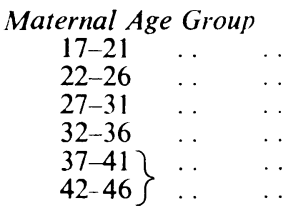 & $\begin{array}{r}73 \\
229 \\
184 \\
157 \\
88 \\
24\end{array}$ & $\left.\begin{array}{r}9 \cdot 7 \\
30 \cdot 3 \\
24 \cdot 4 \\
20 \cdot 8 \\
11 \cdot 7 \\
3 \cdot 2\end{array}\right\}$ & $\begin{array}{r}29 \\
46 \\
31 \\
23 \\
11 \\
1\end{array}$ & $\left.\begin{array}{r}20 \cdot 6 \\
32 \cdot 6 \\
22 \cdot 0 \\
16 \cdot 3 \\
7 \cdot 8 \\
0 \cdot 7\end{array}\right\}$ \\
\hline $\begin{array}{l}\text { Total } \\
\text { Maternal Age } \\
\text { not known }\end{array}$ & $\begin{array}{l}755 \\
-\end{array}$ & $\begin{array}{c}100 \cdot 1 \\
-\end{array}$ & $\begin{array}{r}141 \\
34\end{array}$ & $\begin{array}{r}100 \cdot 0 \\
-\end{array}$ \\
\hline $\begin{array}{c}\text { Birth Rank } \\
1 \ldots \\
2 \text { and } 3 \\
4,5 \text {, and } 6 \\
7+\end{array}$ & $\begin{array}{r}334 \\
264 \\
109 \\
48\end{array}$ & $\begin{array}{r}44 \cdot 2 \\
35 \cdot 0 \\
14 \cdot 4 \\
6 \cdot 4\end{array}$ & $\begin{array}{r}89 \\
52 \\
14 \\
2\end{array}$ & $\begin{array}{r}56 \cdot 7 \\
33 \cdot 1 \\
8 \cdot 9 \\
1 \cdot 3\end{array}$ \\
\hline $\begin{array}{l}\text { Total } \\
\text { Birth Rank not } \\
\text { known }\end{array}$ & 755 & $100 \cdot 0$ & 157 & $100 \cdot 0$ \\
\hline
\end{tabular}

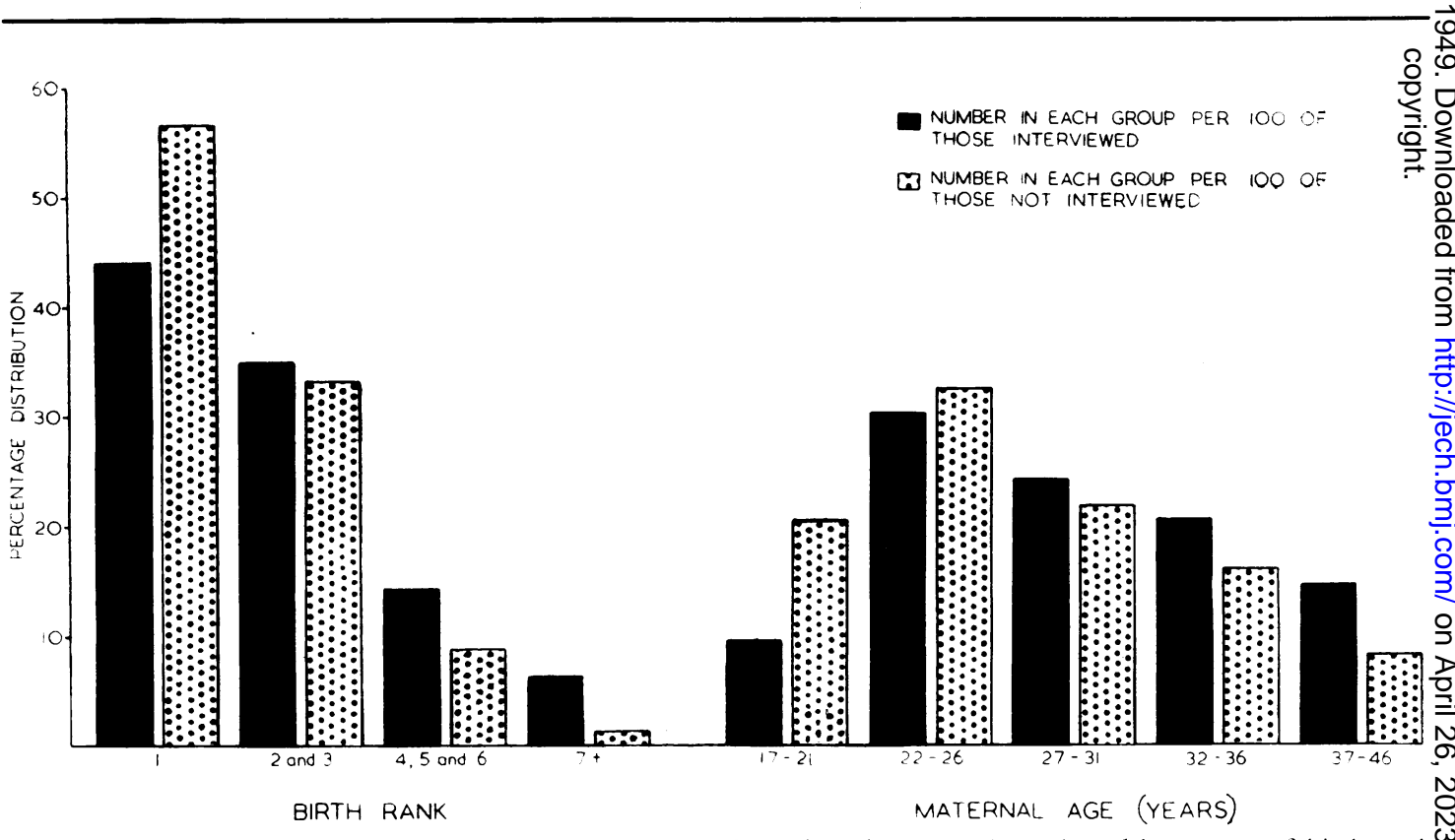
FIG. 6.- Comparis on between mothers of malformations interviewed and not interviewed in respect of birth rank

show that the main discrepancy occurred in 1940 in ward groups I and III. In ward group I (the lowest social group) the proportion of malformations interviewed was consistently lower in the years 1940 to 1945 . In most cases where motherse were not interviewed, details of age and parity were available from central records, and are compared in Table XXII with the sample (Fig. 6.) 
TABLE XXIII

Successfully Traced Central Nervous Malformations Classified according to Type

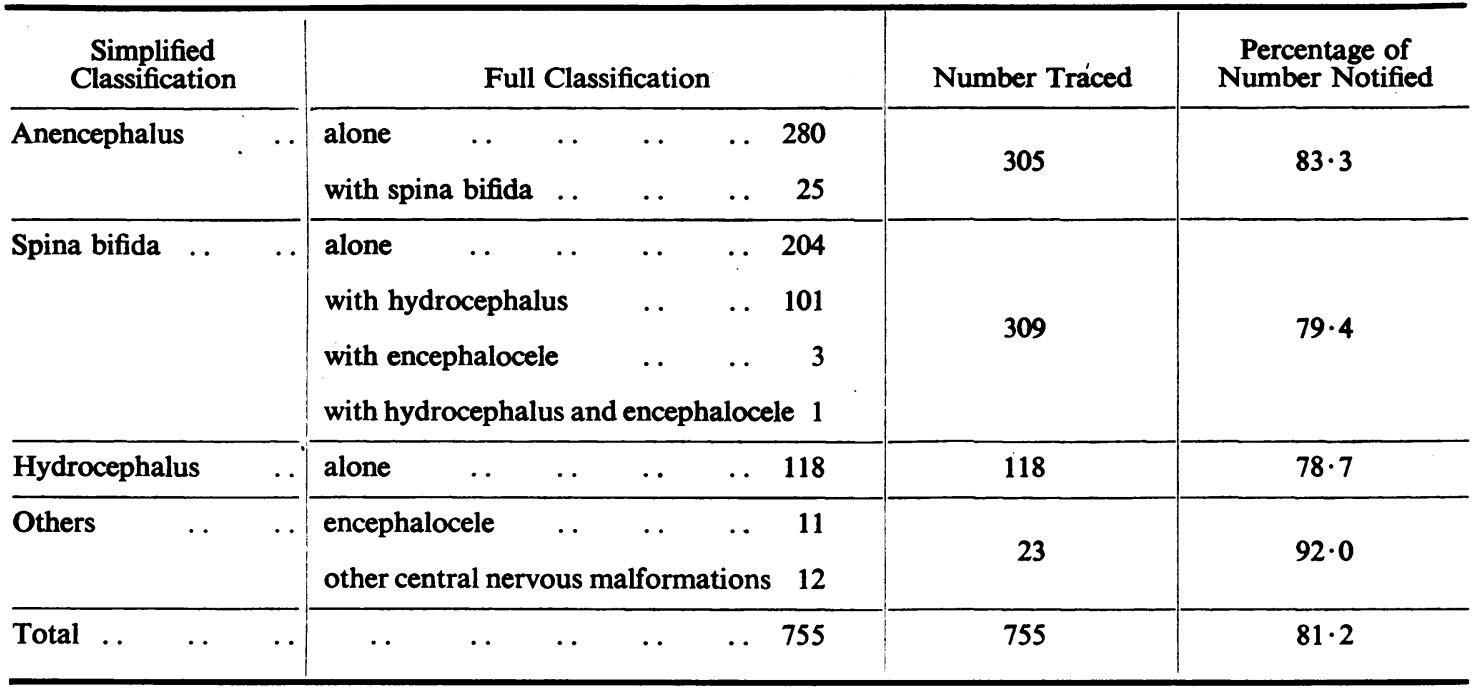

TABLE XXIV (see also Fig. 7)

Numbers of Malformations and Controls at Different Birth Ranks and Maternal Age Groups

\begin{tabular}{|c|c|c|c|c|c|c|c|c|}
\hline \multirow{2}{*}{$\begin{array}{l}\text { Maternal Age } \\
\text { Group }\end{array}$} & \multicolumn{6}{|c|}{ Birth Rank } & \multirow{2}{*}{ Total } & \multirow{2}{*}{$\begin{array}{l}\text { Percentage } \\
\text { Distribution b } \\
\text { Maternal Age }\end{array}$} \\
\hline & 1 & 2 & 3 & 4 & 5 and 6 & $7+$ & & \\
\hline $\begin{array}{c}\text { Malformations } \\
17-21 \\
22-26 \\
27-31 \\
32-36 \\
37-41 \\
42-46\end{array}$ & $\begin{array}{r}66 \\
142 \\
72 \\
43 \\
10 \\
1\end{array}$ & $\begin{array}{r}7 \\
51 \\
57 \\
45 \\
13 \\
-\end{array}$ & $\begin{array}{r}\overline{25} \\
31 \\
25 \\
9 \\
1\end{array}$ & $\begin{array}{r}7 \\
12 \\
16 \\
14 \\
4\end{array}$ & $\begin{array}{r}- \\
4 \\
11 \\
19 \\
18 \\
4\end{array}$ & $\begin{array}{r}- \\
1 \\
9 \\
24 \\
14\end{array}$ & $\begin{array}{r}73 \\
229 \\
184 \\
157 \\
88 \\
24\end{array}$ & $\begin{array}{r}9 \cdot 669 \\
30 \cdot 331 \\
24 \cdot 371 \\
20 \cdot 795 \\
11 \cdot 656 \\
3 \cdot 179\end{array}$ \\
\hline Total & 334 & 173 & 91 & 53 & 56 & 48 & 755 & \\
\hline $\begin{array}{l}\text { Percentage } \\
\text { distribution } \\
\text { by birth rank }\end{array}$ & $44 \cdot 238$ & $22 \cdot 914$ & $12 \cdot 053$ & $7 \cdot 020$ & $7 \cdot 417$ & $6 \cdot 358$ & & $100 \cdot 00$ \\
\hline $\begin{array}{c}\text { Controls } \\
17-21 \\
22-26 \\
27-31 \\
32-36 \\
37-41 \\
42-46\end{array}$ & $\begin{array}{r}56 \\
107 \\
62 \\
20 \\
7 \\
-\end{array}$ & $\begin{array}{r}9 \\
73 \\
78 \\
47 \\
12 \\
2\end{array}$ & $\begin{array}{r}2 \\
29 \\
37 \\
32 \\
8 \\
3\end{array}$ & $\begin{array}{l}71 \\
11 \\
17 \\
26 \\
14 \\
6\end{array}$ & $\begin{array}{r}- \\
2 \\
12 \\
24 \\
19 \\
4\end{array}$ & $\begin{array}{l}- \\
- \\
8 \\
9 \\
6\end{array}$ & $\begin{array}{r}67 \\
222 \\
206 \\
157 \\
69 \\
21\end{array}$ & $\begin{array}{r}9 \cdot 030 \\
29 \cdot 919 \\
27 \cdot 763 \\
21 \cdot 159 \\
9 \cdot 299 \\
2 \cdot 830\end{array}$ \\
\hline Total & 252 & 221 & 111 & 74 & 61 & 23 & 742 & \\
\hline $\begin{array}{l}\text { Percentage } \\
\text { distribution } \\
\text { by birth rank }\end{array}$ & $33 \cdot 962$ & $29 \cdot 784$ & $14 \cdot 960$ & 9.973 & $8 \cdot 221$ & $3 \cdot 100$ & & $100 \cdot 00$ \\
\hline
\end{tabular}

The proportion of first births, and of low maternal' ages, is higher for untraced births, and may be explained by the greater mobility of small families. Malformations of the central nervous system are more common in first than in later births (see below), and this fact may account for the higher proportion untraced. Table XXIII gives the proportion of successful interviews for different malformations. 


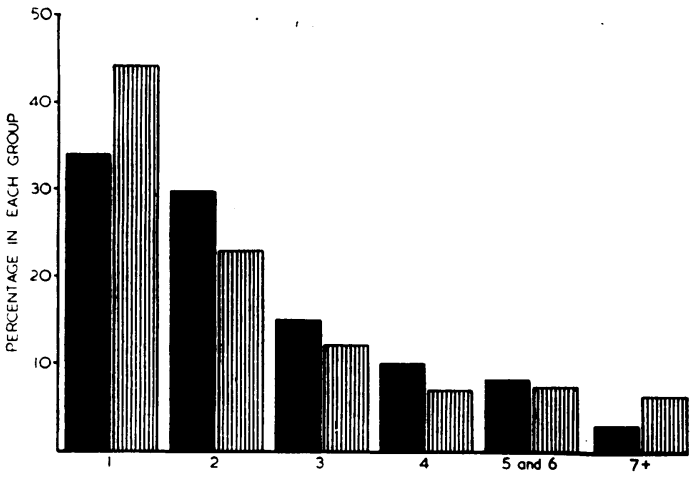

BIRTH RANK

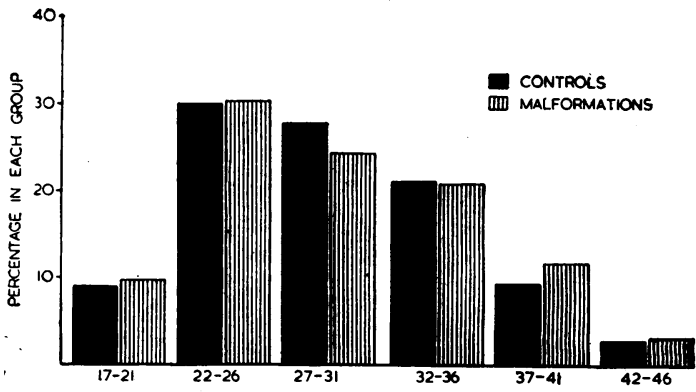

MATERnAL AGE (YEARS)

Fig. 7.-Percentage distribution of malformations and controls at different maternal ages and birth ranks.

TABLE XXV

Numbers of Malformations at Different Birth Ranks and Maternal Ages

\begin{tabular}{|c|c|c|c|c|c|c|c|c|c|c|c|c|c|c|c|}
\hline \multirow{2}{*}{$\begin{array}{c}\text { Maternal } \\
\text { Age } \\
\text { (years) }\end{array}$} & \multicolumn{14}{|c|}{ Birth Rank } & \multirow{2}{*}{ Tota } \\
\hline & 1 & 2 & 3 & 4 & 5 & 6 & 7 & 8 & 9 & 10 & 11 & 12 & 13 & 14 & \\
\hline $\begin{array}{l}17 \\
18 \\
19 \\
20 \\
21\end{array}$ & $\begin{array}{r}2 \\
3 \\
11 \\
24 \\
26\end{array}$ & $\begin{array}{c}- \\
1 \\
2 \\
4\end{array}$ & $\begin{array}{l}E \\
E\end{array}$ & $\begin{array}{l}z \\
z \\
-\end{array}$ & $\begin{array}{l}- \\
- \\
-\end{array}$ & $\begin{array}{l}\dot{-} \\
= \\
=\end{array}$ & $\begin{array}{l}\bar{z} \\
z\end{array}$ & $\begin{array}{l}\bar{E} \\
\overline{-}\end{array}$ & $\begin{array}{l}\text { - } \\
\text { - }\end{array}$ & $\begin{array}{l}E \\
\text { - } \\
-\end{array}$ & $\begin{array}{l}= \\
\bar{z}\end{array}$ & $\begin{array}{l}\text { 二 } \\
\text { - }\end{array}$ & $\begin{array}{l}= \\
\text { 二 }\end{array}$ & $\begin{array}{l}\text { E } \\
\text { - }\end{array}$ & $\begin{array}{l}28 \\
35 \\
126 \\
30\end{array}$ \\
\hline $\begin{array}{l}22 \\
23 \\
24 \\
25 \\
26\end{array}$ & $\begin{array}{l}40 \\
21 \\
29 \\
22 \\
30\end{array}$ & $\begin{array}{r}6 \\
7 \\
13 \\
14 \\
11\end{array}$ & $\begin{array}{r}2 \\
1 \\
4 \\
11 \\
7\end{array}$ & $\frac{\overline{2}}{\overline{1}}$ & $\begin{array}{r}\overline{-} \\
\frac{2}{2} \\
2\end{array}$ & $\begin{array}{l}= \\
=\end{array}$ & $\begin{array}{l}E \\
z \\
-\end{array}$ & $\begin{array}{l}= \\
\bar{z}\end{array}$ & $\begin{array}{l}\bar{z} \\
\overline{-}\end{array}$ & $\begin{array}{l}E \\
= \\
-\end{array}$ & $\begin{array}{l}= \\
=\end{array}$ & $\begin{array}{l}= \\
z\end{array}$ & $\begin{array}{l}= \\
= \\
-\end{array}$ & $\begin{array}{l}E \\
\text { E }\end{array}$ & $\begin{array}{l}48 \\
31 \\
46 \\
50 \\
54\end{array}$ \\
\hline $\begin{array}{l}27 \\
28 \\
29 \\
30 \\
31\end{array}$ & $\begin{array}{r}17 \\
21 \\
14 \\
12 \\
8\end{array}$ & $\begin{array}{r}10 \\
9 \\
12 \\
14 \\
12\end{array}$ & $\begin{array}{r}7 \\
10 \\
6 \\
3 \\
5\end{array}$ & $\begin{array}{r}-\overline{4} \\
2 \\
3 \\
3\end{array}$ & $\frac{1}{-1}$ & $\frac{1}{2} \frac{1}{1}$ & $\begin{array}{l}1 \\
\text { E. }\end{array}$ & $\begin{array}{l}E \\
E \\
E\end{array}$ & $\begin{array}{l}= \\
\bar{E}\end{array}$ & $\begin{array}{l}E \\
E \\
-\end{array}$ & $\begin{array}{l}\text { 二 } \\
\text { I }\end{array}$ & $\begin{array}{l}\text { 二 } \\
\text { 二 }\end{array}$ & $\begin{array}{l}\text { 二 } \\
\text { 二 }\end{array}$ & $\begin{array}{l}z \\
z\end{array}$ & $\begin{array}{l}37 \\
46 \\
34 \\
34 \\
33\end{array}$ \\
\hline $\begin{array}{l}32 \\
33 \\
34 \\
35 \\
36\end{array}$ & $\begin{array}{r}21 \\
9 \\
8 \\
2 \\
3\end{array}$ & $\begin{array}{r}14 \\
12 \\
4 \\
8 \\
7\end{array}$ & $\begin{array}{c}7 \\
6 \\
4 \\
8\end{array}$ & $\begin{array}{c}6 \\
3 \\
3 \\
4\end{array}$ & $\begin{array}{l}2 \\
3 \\
5 \\
1 \\
3\end{array}$ & $\begin{array}{l}\frac{1}{1} \\
\frac{1}{2} \\
1\end{array}$ & $\frac{-}{1}$ & $\begin{array}{l}\overline{2} \\
\overline{-}\end{array}$ & $\begin{array}{r}1 \\
1 \\
3 \\
-\end{array}$ & $\begin{array}{l}\overline{1} \\
-\end{array}$ & $\begin{array}{l}\text { Z } \\
\text { - }\end{array}$ & $\begin{array}{l}\bar{Z} \\
\bar{E}\end{array}$ & $\begin{array}{l}= \\
z\end{array}$ & $\begin{array}{l}\text { E } \\
\text { - }\end{array}$ & $\begin{array}{l}52 \\
28 \\
30 \\
21 \\
26\end{array}$ \\
\hline $\begin{array}{l}37 \\
38 \\
39 \\
40 \\
41\end{array}$ & $\begin{array}{c}\overline{5} \\
1 \\
1 \\
3\end{array}$ & $\begin{array}{c}-4 \\
3 \\
3 \\
3\end{array}$ & $\begin{array}{l}2 \\
1 \\
3 \\
2 \\
1\end{array}$ & $\begin{array}{l}3 \\
5 \\
1 \\
3 \\
2\end{array}$ & $\begin{array}{r}5 \\
2 \\
1 \\
1\end{array}$ & $\begin{array}{c}-1 \\
3 \\
1 \\
4\end{array}$ & $\begin{array}{c}\frac{1}{2} \\
\frac{2}{1}\end{array}$ & $\begin{array}{l}1 \\
4 \\
1 \\
2 \\
1\end{array}$ & $\begin{array}{l}\frac{2}{1} \\
1 \\
-\end{array}$ & $\frac{\overline{1}}{\overline{1}}$ & $\begin{array}{l}\bar{z} \\
\overline{-}\end{array}$ & $\begin{array}{l}\bar{Z} \\
\overline{1}\end{array}$ & $\bar{E}$ & $\begin{array}{l}\overline{-} \\
\overline{1}\end{array}$ & $\begin{array}{l}14 \\
25 \\
13 \\
18 \\
18\end{array}$ \\
\hline $\begin{array}{l}42 \\
43 \\
44 \\
45 \\
46\end{array}$ & $\begin{array}{l}1 \\
-\end{array}$ & $\begin{array}{l}E \\
\text { Z } \\
-\end{array}$ & $\begin{array}{l}1 \\
- \\
-\end{array}$ & $\begin{array}{r}1 \\
2 \\
1 \\
-\end{array}$ & $\begin{array}{r}\overline{1} \\
1 \\
-\end{array}$ & $\begin{array}{l}\frac{1}{1} \\
-\end{array}$ & $\begin{array}{l}\overline{2} \\
\overline{-}\end{array}$ & $\begin{array}{r}1 \\
1 \\
- \\
-\end{array}$ & $\begin{array}{l}\bar{Z} \\
\bar{Z}\end{array}$ & $\begin{array}{r}2 \\
2 \\
\\
1\end{array}$ & $\begin{array}{l}2 \\
- \\
-\end{array}$ & $\begin{array}{r}\overline{1} \\
1 \\
- \\
\end{array}$ & $\begin{array}{l}\text { E } \\
\text { - }\end{array}$ & $\bar{E}$ & $\begin{array}{r}8 \\
10 \\
4 \\
1 \\
1\end{array}$ \\
\hline Total & 334 & 173 & 91 & 53 & 34 & 22 & 10 & 13 & 9 & 8 & 2 & 3 & 1 & 2 & 755 \\
\hline
\end{tabular}


Maternal Age and Parity

DATA DeRIVEd FRom THE SURVEY.-Our examination of the association of maternal age and parity with the risk of a central nervous malformation is based on a comparison between the malformation and control groups. Maternal age was recorded as the age of the mother at the birth of the propositus, and birth rank as one more than the number of all known previous pregnancies (that is, it was determined by the number of pregnancies, and not by the number of live births). Each birth was next allocated to the appropriate cell of a contingency table (Tables XXV and XXVI). Maternal ages and the higher birth ranks have been grouped, and percentage distributions calculated for row and column totals, in Table XXIV (see also Fig. 7). For any age or parity the ratio of the percentage of malformations to the percentage of controls gives a measure of the relative risk of the birth of a malformation, which can be interpreted in relation to an average risk of unity for all ages and parities (Table XXIX and Fig. 8, see p. 204). The figures show that the risk is considerably increased at the first parity and above the sixth, and is correspondingly reduced between these extremes. Variations in association with maternal age are also present, but are less marked.

It is well known that the high correlation between these two variables makes it necessary to separate their effects, and in Table XXVII the risk at different birth ranks is estimated for each five-year maternal age group. The risks noted in association

TABLE XXVI

Numbers of Controls at Different Birth Ranks and Maternal Ages

\begin{tabular}{|c|c|c|c|c|c|c|c|c|c|c|c|c|c|c|c|c|c|c|}
\hline \multirow{2}{*}{$\begin{array}{c}\text { Maternal } \\
\text { Age } \\
\text { (years) }\end{array}$} & \multicolumn{17}{|c|}{ Birth Rank } & \multirow{2}{*}{ Tota } \\
\hline & 1 & 2 & 3 & 4 & 5 & 6 & 7 & 8 & 9 & 10 & 11 & 12 & 13 & 14 & 15 & 16 & 17 & \\
\hline $\begin{array}{l}17 \\
18 \\
19 \\
20 \\
21\end{array}$ & $\begin{array}{r}1 \\
5 \\
16 \\
11 \\
23\end{array}$ & $\frac{-1}{5}$ & $\bar{E}$ & $\begin{array}{l}- \\
\text { - } \\
-\end{array}$ & $\begin{array}{l}\text { 二 } \\
\text { 二 }\end{array}$ & I & $\begin{array}{l}E \\
-\end{array}$ & $\begin{array}{l}\text { 二 } \\
\text { 二 }\end{array}$ & 二 & $\begin{array}{l}\bar{Z} \\
\bar{Z}\end{array}$ & $\begin{array}{l}E \\
E \\
-\end{array}$ & $\begin{array}{l}\text { 二 } \\
\text { - }\end{array}$ & E & $\begin{array}{l}E \\
- \\
-\end{array}$ & $\begin{array}{l}- \\
\text { Z } \\
-\end{array}$ & $\begin{array}{l}- \\
\text { - } \\
-\end{array}$ & $\begin{array}{l}\bar{Z} \\
\overline{-}\end{array}$ & $\begin{array}{r}1 \\
6 \\
16 \\
16 \\
28\end{array}$ \\
\hline $\begin{array}{l}22 \\
23 \\
24 \\
25 \\
26\end{array}$ & $\begin{array}{l}23 \\
33 \\
15 \\
20 \\
16\end{array}$ & $\begin{array}{r}4 \\
19 \\
9 \\
21 \\
20\end{array}$ & $\begin{array}{l}6 \\
5 \\
3 \\
7 \\
8\end{array}$ & $\begin{array}{l}1 \\
1 \\
1 \\
4 \\
4\end{array}$ & $\frac{二}{\frac{1}{2}}$ & $\begin{array}{l}\text { 二 } \\
\text { - }\end{array}$ & $\begin{array}{l}E \\
z\end{array}$ & $\begin{array}{l}\text { 二 } \\
\text { 二 }\end{array}$ & 二 & $\begin{array}{l}\bar{Z} \\
\bar{Z}\end{array}$ & $\begin{array}{l}\text { Z } \\
\text { Z }\end{array}$ & $\begin{array}{l}\text { E } \\
\text { E }\end{array}$ & $\begin{array}{l}- \\
-\end{array}$ & $\begin{array}{l}\text { E } \\
\text { - }\end{array}$ & $\begin{array}{l}\text { 二 } \\
\text { 二 }\end{array}$ & $\begin{array}{l}- \\
\text { E } \\
-\end{array}$ & $\begin{array}{l}\bar{E} \\
\overline{-}\end{array}$ & $\begin{array}{l}34 \\
58 \\
28 \\
52 \\
50\end{array}$ \\
\hline $\begin{array}{l}27 \\
28 \\
29 \\
30 \\
31\end{array}$ & $\begin{array}{r}16 \\
11 \\
19 \\
9 \\
7\end{array}$ & $\begin{array}{r}15 \\
18 \\
16 \\
21 \\
8\end{array}$ & $\begin{array}{r}3 \\
6 \\
7 \\
12 \\
9\end{array}$ & $\begin{array}{l}5 \\
6 \\
2 \\
3 \\
1\end{array}$ & $\begin{array}{l}\overline{2} \\
2 \\
1 \\
3\end{array}$ & $\begin{array}{c}- \\
1 \\
3 \\
-\end{array}$ & $\begin{array}{l}- \\
\bar{Z}\end{array}$ & $\begin{array}{l}\text { 二 } \\
\text { 二 }\end{array}$ & $\begin{array}{l}\bar{z} \\
\bar{z}\end{array}$ & $\begin{array}{l}\bar{Z} \\
\bar{Z}\end{array}$ & $\begin{array}{l}\text { 二 } \\
\text { - }\end{array}$ & $\begin{array}{l}\text { 二 } \\
\text { 二 }\end{array}$ & $\begin{array}{l}E \\
z\end{array}$ & $\begin{array}{l}\text { E } \\
\text { E }\end{array}$ & $\begin{array}{l}\text { 二 } \\
\text { 二 }\end{array}$ & $\begin{array}{l}\text { E } \\
\text { E }\end{array}$ & $\begin{array}{l}\text { 二 } \\
\text { E }\end{array}$ & $\begin{array}{l}39 \\
43 \\
47 \\
49 \\
28\end{array}$ \\
\hline $\begin{array}{l}32 \\
33 \\
34 \\
35 \\
36\end{array}$ & $\begin{array}{l}6 \\
6 \\
3 \\
3 \\
2\end{array}$ & $\begin{array}{r}11 \\
10 \\
7 \\
13 \\
6\end{array}$ & $\begin{array}{l}8 \\
8 \\
7 \\
5 \\
4\end{array}$ & $\begin{array}{l}6 \\
6 \\
4 \\
5 \\
5\end{array}$ & $\begin{array}{l}-3 \\
2 \\
4 \\
3\end{array}$ & $\begin{array}{l}5 \\
1 \\
2 \\
3 \\
1\end{array}$ & $\begin{array}{r}\frac{2}{1} \\
1 \\
-\end{array}$ & $\frac{-}{\frac{1}{1}}$ & $\begin{array}{l}\bar{z} \\
\bar{z}\end{array}$ & $\begin{array}{l}\overline{1} \\
-\end{array}$ & $\frac{-}{1}$ & $\begin{array}{l}\text { 二 } \\
\text { 二 }\end{array}$ & $\begin{array}{l}\text { 二 } \\
\text { - }\end{array}$ & $\begin{array}{l}\text { E } \\
\text { E }\end{array}$ & $\begin{array}{l}\text { 二 } \\
\text { Z }\end{array}$ & $\begin{array}{l}\text { E } \\
\text { - }\end{array}$ & $\begin{array}{l}\text { E } \\
\text { E }\end{array}$ & $\begin{array}{l}38 \\
34 \\
28 \\
35 \\
22\end{array}$ \\
\hline $\begin{array}{l}37 \\
38 \\
39 \\
40 \\
41\end{array}$ & $\begin{array}{r}4 \\
2 \\
- \\
1\end{array}$ & $\begin{array}{r}3 \\
3 \\
3 \\
3 \\
-\end{array}$ & $\begin{array}{c}3 \\
2 \\
2 \\
1\end{array}$ & $\begin{array}{r}4 \\
4 \\
3 \\
3 \\
-\end{array}$ & $\begin{array}{r}7 \\
1 \\
2 \\
4\end{array}$ & $\begin{array}{l}\frac{1}{1} \\
1 \\
2\end{array}$ & $\begin{array}{l}\overline{2} \\
\frac{1}{2}\end{array}$ & $\bar{E}$ & $\frac{\bar{z}}{\overline{1}}$ & $\begin{array}{l}\text { 二 } \\
\text { 二 }\end{array}$ & $\begin{array}{l}\overline{1} \\
-\end{array}$ & $\begin{array}{l}\text { 二 } \\
\text { 二 }\end{array}$ & $\begin{array}{l}\bar{Z} \\
\bar{Z}\end{array}$ & $\begin{array}{l}E \\
\text { E } \\
-\end{array}$ & $\begin{array}{l}\text { 二 } \\
\text { 二 }\end{array}$ & $\begin{array}{l}\text { 二 } \\
\text { E }\end{array}$ & $\begin{array}{l}\bar{E} \\
\bar{E}\end{array}$ & $\begin{array}{l}22 \\
14 \\
11 \\
10 \\
12\end{array}$ \\
\hline $\begin{array}{r}42 \\
43 \\
44 \\
45 \\
46\end{array}$ & $\begin{array}{l}\text { 二 } \\
\text { 二 }\end{array}$ & $\frac{\overline{2}}{\overline{-}}$ & $\frac{2}{1}$ & $\begin{array}{r}4 \\
1 \\
1 \\
-\end{array}$ & $\begin{array}{l}1 \\
\text { 二 }\end{array}$ & $\frac{\overline{2}}{\frac{1}{1}}$ & $\frac{1}{二}$ & $\begin{array}{l}\text { 二 } \\
\text { 二 }\end{array}$ & $\frac{\bar{Z}}{\overline{1}}$ & $\begin{array}{l}E \\
\bar{Z}\end{array}$ & $\frac{\bar{Z}}{\overline{1}}$ & $\begin{array}{l}\text { 二 } \\
\text { 二 }\end{array}$ & $\begin{array}{l}\text { 二 } \\
\text { Z }\end{array}$ & $\frac{1}{二}$ & $\begin{array}{l}\text { 二 } \\
\text { Z }\end{array}$ & 二 & $\frac{\bar{E}}{\overline{1}}$ & $\begin{array}{l}9 \\
3 \\
4 \\
2 \\
3\end{array}$ \\
\hline Total & 252 & 221 & 111 & 74 & 37 & 24 & 10 & 4 & 3 & 1 & 3 & - & - & 1 & - & - & 1 & 742 \\
\hline
\end{tabular}


TABLE XXVII

Distribution of Malformations and Controls in the Same Maternal Age Groups at Different Birth Ranks

\begin{tabular}{|c|c|c|c|c|c|c|c|c|c|c|}
\hline \multirow{2}{*}{$\begin{array}{l}\text { Maternal Age } \\
\text { Group }\end{array}$} & \multirow{2}{*}{$\begin{array}{l}\text { Birth } \\
\text { Rank }\end{array}$} & \multicolumn{3}{|c|}{ Malformations } & \multicolumn{3}{|c|}{ Controls } & \multirow{2}{*}{$\begin{array}{l}\text { Difference } \\
\text { between } \\
\text { percentages }\end{array}$} & \multirow{2}{*}{$\begin{array}{l}\text { Standard } \\
\text { error of } \\
\text { difference }\end{array}$} & \multirow{2}{*}{ 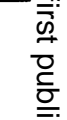 } \\
\hline & & No. & $\%$ & S.E. & No. & $\%$ & S.E. & & & \\
\hline \multirow[t]{2}{*}{$17-21$} & $\begin{array}{l}1 \\
2 \\
3\end{array}$ & $\begin{array}{r}66 \\
7 \\
-\end{array}$ & $\begin{array}{c}90.411 \\
9.589 \\
-\end{array}$ & $\begin{array}{c}3 \cdot 45 \\
3 \cdot 45 \\
-\end{array}$ & $\begin{array}{r}56 \\
9 \\
2\end{array}$ & $\begin{array}{r}83 \cdot 582 \\
13 \cdot 433 \\
2 \cdot 985\end{array}$ & $\begin{array}{l}4 \cdot 53 \\
4 \cdot 16 \\
2 \cdot 08\end{array}$ & $\begin{array}{l}+6.83 \\
-3.84 \\
-2.99\end{array}$ & $\begin{array}{l}5 \cdot 69 \\
5 \cdot 41 \\
2 \cdot 08\end{array}$ & 离 \\
\hline & All ranks & 73 & $100 \cdot 00$ & - & 67 & $100 \cdot 00$ & - & & & $\overrightarrow{0}$ \\
\hline \multirow[t]{2}{*}{$22-26$} & $\begin{array}{c}1 \\
2 \\
3 \\
4 \\
5 \text { and } 6\end{array}$ & $\begin{array}{r}142 \\
51 \\
25 \\
7 \\
4\end{array}$ & $\begin{array}{r}62 \cdot 009 \\
22 \cdot 271 \\
10 \cdot 917 \\
3 \cdot 057 \\
1 \cdot 747\end{array}$ & $\begin{array}{l}3.21 \\
2.75 \\
2.06 \\
1.44 \\
0.87\end{array}$ & \begin{tabular}{r|r}
107 \\
73 \\
29 \\
11 \\
2
\end{tabular} & $\begin{array}{r}48 \cdot 198 \\
32 \cdot 883 \\
13 \cdot 063 \\
4 \cdot 955 \\
0 \cdot 901\end{array}$ & $\begin{array}{l}3 \cdot 35 \\
3 \cdot 15 \\
2 \cdot 26 \\
1 \cdot 46 \\
0 \cdot 63\end{array}$ & $\begin{array}{l}+13.81^{*} \\
-10.61^{*} \\
-2.15^{*} \\
-1.90 \\
+0.85\end{array}$ & $\begin{array}{l}4.64 \\
4 \cdot 18 \\
3.06 \\
1 \cdot 85 \\
1 \cdot 07\end{array}$ & 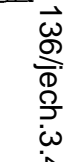 \\
\hline & All ranks & 229 & $100 \cdot 00$ & - & 222 & $100 \cdot 00$ & - & & & $\vec{\infty}$ \\
\hline \multirow[t]{2}{*}{$27-31$} & $\begin{array}{c}1 \\
2 \\
3 \\
4 \\
5 \text { and } 6 \\
7+\end{array}$ & \begin{tabular}{r|r}
72 & \\
57 & \\
31 & \\
12 & \\
11 & \\
1 &
\end{tabular} & $\begin{array}{r}39 \cdot 130 \\
30 \cdot 978 \\
16 \cdot 848 \\
6 \cdot 522 \\
5 \cdot 978 \\
0 \cdot 543\end{array}$ & $\begin{array}{l}3 \cdot 60 \\
3 \cdot 41 \\
2 \cdot 76 \\
1 \cdot 82 \\
1 \cdot 75 \\
0 \cdot 54\end{array}$ & $\begin{array}{l}62 \\
78 \\
37 \\
17 \\
12 \\
-\end{array}$ & $\begin{array}{c}30 \cdot 097 \\
37 \cdot 864 \\
17 \cdot 961 \\
8 \cdot 252 \\
5 \cdot 825 \\
-\end{array}$ & $\begin{array}{l}3 \cdot 20 \\
3 \cdot 38 \\
2 \cdot 67 \\
1 \cdot 92 \\
1 \cdot 63 \\
-\end{array}$ & $\begin{array}{l}+9.03 \\
-6.89 \\
-1.11 \\
-1.73 \\
+0.15 \\
+0.54\end{array}$ & $\begin{array}{l}4 \cdot 81 \\
4 \cdot 80 \\
3 \cdot 84 \\
2 \cdot 64 \\
2 \cdot 39 \\
0 \cdot 54\end{array}$ & 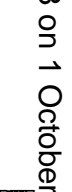 \\
\hline & All ranks & 184 & $100 \cdot 00$ & - & 206 & $100 \cdot 00$ & - & & & $\vec{\omega}$ \\
\hline \multirow[t]{2}{*}{$32-36$} & $\begin{array}{c}1 \\
2 \\
3 \\
4 \\
5 \text { and } 6 \\
7+\end{array}$ & $\begin{array}{r}43 \\
45 \\
25 \\
16 \\
19 \\
9\end{array}$ & $\begin{array}{r}27 \cdot 389 \\
28 \cdot 662 \\
15 \cdot 924 \\
10 \cdot 191 \\
12 \cdot 102 \\
5 \cdot 732\end{array}$ & $\begin{array}{l}3 \cdot 56 \\
3 \cdot 61 \\
2 \cdot 92 \\
2 \cdot 41 \\
2 \cdot 60 \\
1 \cdot 86\end{array}$ & $\begin{array}{r}20 \\
47 \\
32 \\
26 \\
24 \\
8\end{array}$ & $\begin{array}{r}12 \cdot 739 \\
29 \cdot 936 \\
20 \cdot 382 \\
16 \cdot 561 \\
15 \cdot 287 \\
5 \cdot 096\end{array}$ & $\begin{array}{l}2 \cdot 66 \\
3 \cdot 65 \\
3 \cdot 21 \\
2 \cdot 97 \\
2 \cdot 87 \\
1 \cdot 75\end{array}$ & $\begin{array}{l}+14 \cdot 65^{*} \\
-1 \cdot 27 \\
-4 \cdot 46 \\
-6 \cdot 37 \\
-3 \cdot 18 \\
+0.64\end{array}$ & $\begin{array}{l}4 \cdot 44 \\
5 \cdot 14 \\
4 \cdot 34 \\
3 \cdot 82 \\
3 \cdot 88 \\
2 \cdot 55\end{array}$ & 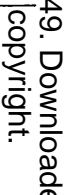 \\
\hline & All ranks & 157 & $100 \cdot 00$ & - & 157 & $100 \cdot 00$ & - & & & $\stackrel{\varrho}{\rightleftarrows}$ \\
\hline \multirow[t]{2}{*}{$37-41$} & $\begin{array}{c}1 \\
2 \\
3 \\
4 \\
5 \text { and } 6 \\
7+\end{array}$ & $\begin{array}{r}10 \\
13 \\
9 \\
14 \\
18 \\
24\end{array}$ & $\begin{array}{l}11 \cdot 364 \\
14 \cdot 773 \\
10 \cdot 227 \\
15 \cdot 909 \\
20 \cdot 455 \\
27 \cdot 273\end{array}$ & $\begin{array}{l}3 \cdot 38 \\
3 \cdot 78 \\
3 \cdot 23 \\
3 \cdot 90 \\
4 \cdot 30 \\
4 \cdot 75\end{array}$ & $\begin{array}{r}7 \\
12 \\
8 \\
14 \\
19 \\
9\end{array}$ & $\begin{array}{l}10 \cdot 145 \\
17 \cdot 391 \\
11 \cdot 594 \\
20 \cdot 290 \\
27 \cdot 536 \\
13 \cdot 043\end{array}$ & $\begin{array}{l}3 \cdot 63 \\
4 \cdot 56 \\
3 \cdot 85 \\
4 \cdot 84 \\
5 \cdot 38 \\
4 \cdot 05\end{array}$ & $\begin{array}{l}+1 \cdot 22 \\
-2 \cdot 62 \\
-1 \cdot 37 \\
-4 \cdot 38 \\
-7 \cdot 08 \\
+14 \cdot 23^{*}\end{array}$ & $\begin{array}{l}4 \cdot 97 \\
5 \cdot 93 \\
5 \cdot 03 \\
6 \cdot 22 \\
6 \cdot 89 \\
6 \cdot 24\end{array}$ & 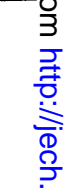 \\
\hline & All ranks & 88 & $100 \cdot 00$ & - & 69 & $100 \cdot 00$ & - & - & & $\underline{3}$. \\
\hline \multirow[t]{2}{*}{$42-46$} & $\begin{array}{c}1 \\
2 \\
3 \\
4 \\
5 \text { and } 6 \\
7+\end{array}$ & \begin{tabular}{r|}
1 \\
1 \\
4 \\
4 \\
14
\end{tabular} & $\begin{array}{c}4 \cdot 167 \\
\overline{4} \cdot 167 \\
16 \cdot 667 \\
16 \cdot 667 \\
58 \cdot 333\end{array}$ & $\begin{array}{r}4 \cdot 08 \\
-.08 \\
7 \cdot 61 \\
7 \cdot 61 \\
10 \cdot 06\end{array}$ & $\begin{array}{l}-2 \\
3 \\
6 \\
4 \\
6\end{array}$ & $\begin{array}{r}9 \cdot \overline{5} 24 \\
14 \cdot 286 \\
28 \cdot 571 \\
19 \cdot 048 \\
28 \cdot 571\end{array}$ & $\begin{array}{c}-\overline{6} \\
7 \cdot 40 \\
9 \cdot 86 \\
8 \cdot 57 \\
9 \cdot 86\end{array}$ & $\begin{array}{l}+4 \cdot 17 \\
-9 \cdot 52 \\
-10 \cdot 12 \\
-11 \cdot 90 \\
-2 \cdot 38 \\
+29 \cdot 76^{*}\end{array}$ & $\begin{array}{r}4 \cdot 08 \\
6 \cdot 40 \\
8 \cdot 66 \\
12 \cdot 45 \\
11 \cdot 46 \\
14 \cdot 09\end{array}$ & 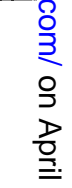 \\
\hline & All ranks & 24 & $100 \cdot 00$ & - & 21 & $100 \cdot 00$ & - & & & O \\
\hline All ages & $\begin{array}{c}1 \\
2 \\
3 \\
4 \\
5 \text { and } 6 \\
7+\end{array}$ & $\begin{array}{r}334 \\
173 \\
91 \\
53 \\
56 \\
48\end{array}$ & $\begin{array}{r}44 \cdot 238 \\
22 \cdot 914 \\
12 \cdot 053 \\
7 \cdot 020 \\
7 \cdot 417 \\
6 \cdot 358\end{array}$ & $\begin{array}{l}1.81 \\
1.53 \\
1.18 \\
0.93 \\
0.95 \\
0.89\end{array}$ & $\begin{array}{r}252 \\
221 \\
111 \\
74 \\
61 \\
23\end{array}$ & $\begin{array}{r}33 \cdot 962 \\
29 \cdot 784 \\
14 \cdot 960 \\
9 \cdot 973 \\
8 \cdot 221 \\
3 \cdot 100\end{array}$ & $\begin{array}{l}1.74 \\
1.68 \\
1.31 \\
1.10 \\
1.01 \\
0.64\end{array}$ & $\begin{array}{l}+10 \cdot 28^{*} \\
-6 \cdot 87^{*} \\
-2 \cdot 91 \\
-2 \cdot 95^{*} \\
-0.80 \\
+3 \cdot 26^{*}\end{array}$ & $\begin{array}{l}2.51 \\
2.27 \\
1.77 \\
1.44 \\
1.39 \\
1.09\end{array}$ & 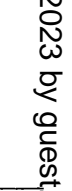 \\
\hline \multicolumn{2}{|l|}{ Total all ranks } & 755 & $100 \cdot 00$ & - & 742 & $100 \cdot 00$ & - & & & 꿍 \\
\hline
\end{tabular}


-TABLE XXVIII

Distribution of Malformations and Controls in the Same Birth Ranks at Different Maternal Age Groups

\begin{tabular}{|c|c|c|c|c|c|c|c|c|c|}
\hline \multirow{2}{*}{$\begin{array}{l}\text { Birth } \\
\text { Rank }\end{array}$} & \multirow{2}{*}{$\begin{array}{l}\text { Maternal Age } \\
\text { Group }\end{array}$} & \multicolumn{3}{|c|}{ Malformations } & \multicolumn{3}{|c|}{ Controls } & \multirow{2}{*}{$\begin{array}{l}\text { Difference } \\
\text { between } \\
\text { percentages }\end{array}$} & \multirow{2}{*}{$\begin{array}{l}\text { Standard } \\
\text { error of } \\
\text { difference }\end{array}$} \\
\hline & & No. & $\%$ & S.E. & No. & $\%$ & S.E. & & \\
\hline \multirow[t]{2}{*}{1} & $\begin{array}{l}17-21 \\
22-26 \\
27-31 \\
32-36 \\
37-41 \\
42-46\end{array}$ & $\begin{array}{r}66 \\
142 \\
72 \\
43 \\
10 \\
1\end{array}$ & $\begin{array}{r}19 \cdot 760 \\
42 \cdot 515 \\
21 \cdot 557 \\
12 \cdot 874 \\
\cdot 2 \cdot 994 \\
0 \cdot 299\end{array}$ & $\begin{array}{l}2 \cdot 18 \\
2 \cdot 70 \\
2 \cdot 25 \\
1 \cdot 83 \\
0 \cdot 93 \\
0 \cdot 30\end{array}$ & $\begin{array}{r}56 \\
107 \\
62 \\
20 \\
7 \\
-\end{array}$ & $\begin{array}{c}22 \cdot 222 \\
42 \cdot 460 \\
24 \cdot 603 \\
7 \cdot 937 \\
2 \cdot 778 \\
-\end{array}$ & $\begin{array}{l}2 \cdot 62 \\
3 \cdot 11 \\
2 \cdot 71 \\
1 \cdot 70 \\
1 \cdot 03 \\
-\end{array}$ & $\begin{array}{l}-2.46 \\
+0.06 \\
+3.05 \\
+4.94 \\
+0.22 \\
+0.30\end{array}$ & $\begin{array}{l}3 \cdot 41 \\
4 \cdot 12 \\
3 \cdot 52 \\
2 \cdot 50 \\
1 \cdot 39 \\
0 \cdot 30\end{array}$ \\
\hline & All groups & 334 & $100 \cdot 00$ & - & 252 & $100 \cdot 00$ & - & & \\
\hline \multirow[t]{2}{*}{2} & $\begin{array}{l}17-21 \\
22-26 \\
27-31 \\
32-36 \\
37-41 \\
42-46\end{array}$ & $\begin{array}{r}7 \\
51 \\
57 \\
45 \\
13 \\
-\end{array}$ & $\begin{array}{r}4 \cdot 046 \\
29 \cdot 480 \\
32 \cdot 948 \\
26 \cdot 012 \\
7 \cdot 514 \\
-\end{array}$ & $\begin{array}{l}1 \cdot 50 \\
3 \cdot 47 \\
3 \cdot 57 \\
3 \cdot 34 \\
2 \cdot 00 \\
-\end{array}$ & $\begin{array}{r}9 \\
73 \\
78 \\
47 \\
12 \\
2\end{array}$ & $\begin{array}{r}4 \cdot 072 \\
33 \cdot 032 \\
35 \cdot 294 \\
21 \cdot 267 \\
5 \cdot 430 \\
0 \cdot 905\end{array}$ & $\begin{array}{l}1 \cdot 33 \\
3 \cdot 16 \\
3 \cdot 21 \\
2 \cdot 75 \\
1 \cdot 52 \\
0 \cdot 64\end{array}$ & $\begin{array}{r}-0.03 \\
-3.55 \\
-2.35 \\
+4.74 \\
+2.08 \\
-0.90\end{array}$ & $\begin{array}{l}2 \cdot 00 \\
4 \cdot 69 \\
4 \cdot 81 \\
4 \cdot 32 \\
2 \cdot 52 \\
0 \cdot 64\end{array}$ \\
\hline & All groups & 173 & $100 \cdot 00$ & - & 221 & $100 \cdot 00$ & - & & \\
\hline \multirow[t]{2}{*}{3} & $\begin{array}{l}17-21 \\
22-26 \\
27-31 \\
32-36 \\
37-41 \\
42-46\end{array}$ & $\begin{array}{r}\overline{25} \\
31 \\
25 \\
9 \\
1\end{array}$ & $\begin{array}{r}-\overline{27 \cdot 473} \\
34 \cdot 066 \\
27 \cdot 473 \\
9 \cdot 890 \\
1 \cdot 099\end{array}$ & $\begin{array}{l}-\overline{4} \\
4 \cdot 68 \\
4 \cdot 97 \\
4 \cdot 68 \\
3 \cdot 13 \\
1 \cdot 69\end{array}$ & $\begin{array}{r}2 \\
29 \\
37 \\
32 \\
8 \\
3\end{array}$ & $\begin{array}{r}1 \cdot 802 \\
26 \cdot 126 \\
33 \cdot 333 \\
28 \cdot 829 \\
7 \cdot 207 \\
2 \cdot 703\end{array}$ & $\begin{array}{l}1 \cdot 26 \\
4 \cdot 17 \\
4 \cdot 47 \\
4 \cdot 30 \\
2 \cdot 45 \\
1 \cdot 54\end{array}$ & $\begin{array}{l}-1.80 \\
+1.35 \\
+0.73 \\
-1.36 \\
+2.68 \\
-1.60\end{array}$ & $\begin{array}{l}1 \cdot 26 \\
6 \cdot 27 \\
6 \cdot 69 \\
6 \cdot 35 \\
3 \cdot 98 \\
1 \cdot 89\end{array}$ \\
\hline & All groups & 91 & $100 \cdot 00$ & - & 111 & $100 \cdot 00$ & - & & \\
\hline \multirow[t]{2}{*}{4} & $\begin{array}{l}22-26 \\
27-31 \\
32-36 \\
37-41 \\
42-46\end{array}$ & $\begin{array}{r}7 \\
12 \\
16 \\
14 \\
4\end{array}$ & $\begin{array}{r}13 \cdot 208 \\
22 \cdot 642 \\
30 \cdot 189 \\
26 \cdot 415 \\
7 \cdot 547\end{array}$ & $\begin{array}{l}4 \cdot 65 \\
5 \cdot 75 \\
6 \cdot 31 \\
6 \cdot 06 \\
3 \cdot 63\end{array}$ & $\begin{array}{r}11 \\
17 \\
26 \\
14 \\
6\end{array}$ & $\begin{array}{r}14 \cdot 865 \\
22 \cdot 973 \\
35 \cdot 135 \\
18 \cdot 919 \\
8 \cdot 108\end{array}$ & $\begin{array}{l}4 \cdot 14 \\
4 \cdot 89 \\
5 \cdot 55 \\
4 \cdot 55 \\
3 \cdot 17\end{array}$ & $\begin{array}{l}-1.66 \\
-0.33 \\
-4.95 \\
+7.50 \\
-0.56\end{array}$ & $\begin{array}{l}6 \cdot 22 \\
7 \cdot 55 \\
8 \cdot 40 \\
7 \cdot 58 \\
4 \cdot 82\end{array}$ \\
\hline & All groups & 53 & $100 \cdot 00$ & - & 74 & $100 \cdot 00$ & - & & \\
\hline \multirow[t]{2}{*}{5 and 6} & $\begin{array}{l}22-26 \\
27-31 \\
32-36 \\
37-41 \\
42-46\end{array}$ & $\begin{array}{r}4 \\
11 \\
19 \\
18 \\
4\end{array}$ & $\begin{array}{r}7 \cdot 143 \\
19 \cdot 643 \\
33 \cdot 928 \\
32 \cdot 143 \\
7 \cdot 143\end{array}$ & $\begin{array}{l}3 \cdot 44 \\
5 \cdot 32 \\
6 \cdot 33 \\
6 \cdot 24 \\
3 \cdot 44\end{array}$ & $\begin{array}{r}2 \\
12 \\
24 \\
19 \\
4\end{array}$ & $\begin{array}{r}3 \cdot 279 \\
19 \cdot 672 \\
39 \cdot 344 \\
31 \cdot 148 \\
6 \cdot 557\end{array}$ & $\begin{array}{l}2 \cdot 28 \\
5 \cdot 09 \\
6 \cdot 25 \\
5 \cdot 93 \\
3 \cdot 17\end{array}$ & $\begin{array}{l}+3.86 \\
-0.03 \\
-5.42 \\
+0.99 \\
+0.59\end{array}$ & $\begin{array}{l}4 \cdot 13 \\
7 \cdot 35 \\
8 \cdot 90 \\
8 \cdot 61 \\
4 \cdot 68\end{array}$ \\
\hline & All groups & 56 & $100 \cdot 00$ & - & 61 & $100 \cdot 00$ & - & & \\
\hline \multirow[t]{2}{*}{$7+$} & $\begin{array}{l}27-31 \\
32-36 \\
37-41 \\
42-46\end{array}$ & $\begin{array}{r}1 \\
9 \\
24 \\
14\end{array}$ & $\begin{array}{r}2 \cdot 083 \\
18 \cdot 750 \\
50 \cdot 000 \\
29 \cdot 167\end{array}$ & $\begin{array}{l}2 \cdot 06 \\
5 \cdot 63 \\
7 \cdot 22 \\
6 \cdot 56\end{array}$ & $\begin{array}{l}-8 \\
9 \\
6\end{array}$ & $\begin{array}{l}34 \overline{7} \\
39 \cdot 130 \\
26 \cdot 087\end{array}$ & $\begin{array}{r}-\overline{9} .93 \\
10 \cdot 17 \\
9 \cdot 16\end{array}$ & $\begin{array}{r}+2.08 \\
+16.03 \\
+10.87 \\
+\quad 3.08\end{array}$ & $\begin{array}{r}2 \cdot 06 \\
11 \cdot 42 \\
12 \cdot 48 \\
11 \cdot 26\end{array}$ \\
\hline & All groups & 48 & $100 \cdot 00$ & - & 23 & $100 \cdot 00$ & - & & \\
\hline $\begin{array}{l}\text { All } \\
\text { birth } \\
\text { ranks }\end{array}$ & $\begin{array}{l}17-21 \\
22-26 \\
27-31 \\
32-36 \\
37-41 \\
42-46\end{array}$ & $\begin{array}{r}73 \\
229 \\
184 \\
157 \\
88 \\
24\end{array}$ & $\begin{array}{r}9 \cdot 669 \\
30 \cdot 331 \\
24 \cdot 371 \\
20 \cdot 795 \\
11 \cdot 656 \\
3 \cdot 179\end{array}$ & $\begin{array}{l}1.07 \\
1.67 \\
1.56 \\
1.48 \\
1.17 \\
0.64\end{array}$ & $\begin{array}{r}67 \\
222 \\
206 \\
157 \\
69 \\
21\end{array}$ & $\begin{array}{r}9 \cdot 030 \\
29 \cdot 919 \\
27 \cdot 763 \\
21 \cdot 159 \\
9 \cdot 299 \\
2 \cdot 830\end{array}$ & $\begin{array}{l}1.05 \\
1.68 \\
1.64 \\
1.50 \\
1.07 \\
0.61\end{array}$ & $\begin{array}{l}+0.64 \\
+0.41 \\
+3.39 \\
-0.36 \\
+2.36 \\
+0.35\end{array}$ & $\begin{array}{l}1 \cdot 50 \\
2 \cdot 37 \\
2 \cdot 27 \\
2 \cdot 10 \\
1 \cdot 58 \\
0 \cdot 88\end{array}$ \\
\hline \multicolumn{2}{|c|}{ Total all groups } & 755 & $100 \cdot 00$ & - & 742 & $100 \cdot 00$ & - & & \\
\hline
\end{tabular}


TABLE XXIX (see also Fig. 8)

Percentage Distribution of Malformations and Controls at Different Birth Ranks and Maternal Age GROUPS

\begin{tabular}{|c|c|c|c|c|c|}
\hline & \multicolumn{4}{|c|}{ Distribution } & \multirow{3}{*}{$\begin{array}{l}\text { Relative Risk of a } \\
\text { Malformation }\end{array}$} \\
\hline & \multicolumn{2}{|c|}{ Malformations } & \multicolumn{2}{|c|}{ Controls } & \\
\hline & Number & Percentage & Number & Percentage & \\
\hline $\begin{array}{r}\text { Birth Rank } \\
1 \\
2 \\
3 \\
4 \\
5 \text { and } 6 \\
7+\end{array}$ & $\begin{array}{r}334 \\
173 \\
91 \\
53 \\
56 \\
48\end{array}$ & $\begin{array}{r}44 \cdot 24 \\
22 \cdot 91 \\
12 \cdot 05 \\
7 \cdot 02 \\
7 \cdot 42 \\
6 \cdot 36 \\
\end{array}$ & $\begin{array}{r}252 \\
221 \\
111 \\
74 \\
61 \\
23\end{array}$ & $\begin{array}{r}33 \cdot 96 \\
29 \cdot 78 \\
14 \cdot 96 \\
9 \cdot 97 \\
8 \cdot 22 \\
3 \cdot 10\end{array}$ & $\begin{array}{l}1 \cdot 30 \\
0 \cdot 77 \\
0 \cdot 81 \\
0 \cdot 70 \\
0 \cdot 90 \\
2 \cdot 05\end{array}$ \\
\hline All birth ranks & 755 & $100 \cdot 00$ & 742 & $99 \cdot 99$ & $1 \cdot 00$ \\
\hline $\begin{array}{c}\text { Maternal Age Group } \\
17-21 \\
22-26 \\
27-31 \\
32-36 \\
37-41 \\
42-46 \\
\end{array}$ & $\begin{array}{r}73 \\
229 \\
184 \\
157 \\
88 \\
24\end{array}$ & $\begin{array}{r}9 \cdot 67 \\
30 \cdot 33 \\
24 \cdot 37 \\
20 \cdot 79 \\
11 \cdot 66 \\
3 \cdot 18 \\
\end{array}$ & $\begin{array}{r}67 \\
222 \\
206 \\
157 \\
69 \\
21\end{array}$ & $\begin{array}{r}9 \cdot 03 \\
29 \cdot 92 \\
27 \cdot 76 \\
21 \cdot 16 \\
9 \cdot 30 \\
2 \cdot 83\end{array}$ & $\begin{array}{l}1 \cdot 07 \\
1.01 \\
0 \cdot 88 \\
0 \cdot 98 \\
1 \cdot 25 \\
1 \cdot 12\end{array}$ \\
\hline All age groups & 755 & $100 \cdot 00$ & 742 & $100 \cdot 00$ & $1 \cdot 00$ \\
\hline
\end{tabular}

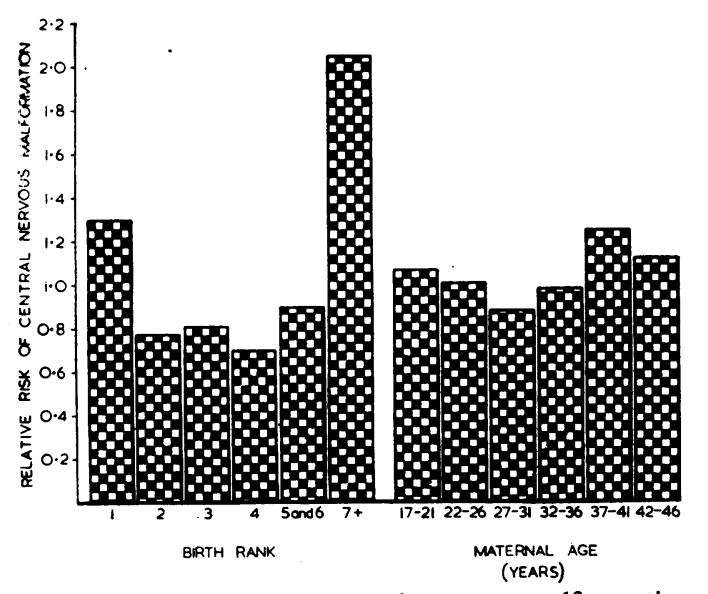

FIG. 8.-Relative risk of central nervous malformations at different birth ranks and maternal ages.

with parity for the whole series are fairly consistently reflected in the more detailed figures, although in some groups the numbers are small. It will be recalled that interviews were not completed for a higher proportion of mothers in the malformation series, and since first births were more common among mothers not traced, the effect of primiparity is likely to be somewhat greater than that indicated by the figures.
In Table XXVIII the same procedure is adopted the examination of the effect of maternal age at different birth ranks; the figures demonstrate no consistent association between maternal age and $\stackrel{\mathbb{Q}}{\mathbb{Q}}$ the incidence of malformations, when birth rank is $\overrightarrow{\vec{A}}$ kept constant. Our data also enable us to examine $\frac{0}{3}$ the association of age and parity with the different $כ$ types of central nervous malformation included in this study (Table XXX and Figs. 9 and 10, opposite), although the smaller numbers do not permit a separa- $\stackrel{\bigcirc}{?}$ tion of their effects. For anencephalus and spina bifida the results are similar to those already quoted 3 . for the whole series, but for hydrocephalus the effect $\delta$ of birth rank is slight when compared with the marked effect of high maternal age.

Before accepting these conclusions it is necessary? to consider two possible criticisms of the validityo of the method on which they are based. In the first place, if malformations were more common ino families of low fertility, or if the birth of a malforma- $N$ tion often induced parents to avoid further preg-N nancies, a disproportionate number of malforma- tions would be expected in the lower birth ranks, and especially in the first birth rank. Table XXXIC and Fig. 11 (p. 206) show that the malformation ando control groups are reasonably comparable in respect of the mean number of pregnancies. Indeed, theo figure is slightly higher for the malformations, $\overrightarrow{\mathbb{D}}$ 
TABLE XXX

Malformations of Different Types distributed by Birth Rank and Maternal Age Group

\begin{tabular}{|c|c|c|c|c|c|c|c|c|c|}
\hline & & \multicolumn{4}{|c|}{ Birth Rank } & \multicolumn{4}{|c|}{ Maternal Age Group } \\
\hline & & 1 & $2-6$ & $7+$ & Total & $17-26$ & $27-36$ & $37-46$ & Total \\
\hline Controls & $\begin{array}{lll}\text { Number .. } & \ldots & . \\
\text { Percentage } & \ldots & \\
\text { Standard error } & . . & \text {. }\end{array}$ & $\begin{array}{c}252 \\
33.962 \\
1.74\end{array}$ & $\mid \begin{array}{c}467 \\
62 \cdot 938 \\
1 \cdot 77\end{array}$ & $\begin{array}{l}23 \\
3 \cdot 100 \\
0 \cdot 64\end{array}$ & $\begin{array}{l}742 \\
100\end{array}$ & $\begin{array}{c}289 \\
38 \cdot 949 \\
1 \cdot 79\end{array}$ & $\begin{array}{c}363 \\
48.922 \\
1.83\end{array}$ & $\begin{array}{l}90 \\
12 \cdot 129 \\
1 \cdot 20\end{array}$ & $\begin{array}{l}742 \\
100\end{array}$ \\
\hline Anencephalus & $\begin{array}{ll}\text { Number } & . . \\
\text { Percentage } & \ldots \\
\text { Standard error } & \ldots \\
\text { Difference from Control }\end{array}$ & $\mid$\begin{tabular}{c|}
142 \\
$46 \cdot 557$ \\
$2 \cdot 86$ \\
$+12 \cdot 59 *$ \\
$\pm 3 \cdot 34$
\end{tabular} & \begin{tabular}{|c|}
146 \\
$47 \cdot 869$ \\
$2 \cdot 86$ \\
$-15 \cdot 07 *$ \\
$\pm 3 \cdot 36$
\end{tabular} & $\begin{array}{r}17 \\
5 \cdot 574 \\
1 \cdot 31 \\
+2 \cdot 47 \\
\pm 1 \cdot 46\end{array}$ & $\begin{array}{l}305 \\
100\end{array}$ & \begin{tabular}{r|}
126 \\
$41 \cdot 311$ \\
$2 \cdot 82$ \\
$+2 \cdot 36$ \\
$\pm 3 \cdot 34$
\end{tabular} & $\begin{array}{c}139 \\
45 \cdot 574 \\
2 \cdot 85 \\
-3 \cdot 35 \\
\pm 3 \cdot 39\end{array}$ & $\begin{array}{c}40 \\
13 \cdot 115 \\
1 \cdot 93 \\
+0 \cdot 99 \\
\pm 2 \cdot 27\end{array}$ & $\begin{array}{l}305 \\
100\end{array}$ \\
\hline Spina bifida & $\begin{array}{ll}\text { Number } . . & \ldots \\
\text { Percentage } & \ldots \\
\text { Standard error } \\
\text { Difference from Control }\end{array}$ & $\begin{array}{c}140 \\
45 \cdot 307 \\
2 \cdot 83 \\
+11 \cdot 34 * \\
\pm 3 \cdot 32\end{array}$ & \begin{tabular}{|c|}
148 \\
$47 \cdot 897$ \\
$2 \cdot 84$ \\
$-15 \cdot 04$ \\
$\pm 3 \cdot 35$
\end{tabular} & $\begin{array}{c}21 \\
6 \cdot 796 \\
1 \cdot 43 \\
+3 \cdot 70 \\
\pm 1 \cdot 57\end{array}$ & $\begin{array}{l}309 \\
100\end{array}$ & $\begin{array}{c}130 \\
42 \cdot 071 \\
2 \cdot 81 \\
+3 \cdot 12 \\
\pm 3 \cdot 33\end{array}$ & $\begin{array}{c}133 \\
43 \cdot 042 \\
2 \cdot 82 \\
-5 \cdot 88 \\
\pm 3 \cdot 36\end{array}$ & $\begin{array}{l}46 \\
14 \cdot 887 \\
2 \cdot 02 \\
+2 \cdot 76 \\
\pm 2 \cdot 35\end{array}$ & $\begin{array}{l}309 \\
100\end{array}$ \\
\hline Hydrocephalus & $\begin{array}{ll}\text { Number } & \ldots \\
\text { Percentage } & \ldots \\
\text { Standard error } \\
\text { Difference from Control }\end{array}$ & \begin{tabular}{|l|}
43 \\
$36 \cdot 441$ \\
$4 \cdot 43$ \\
$+2 \cdot 48$ \\
$\pm 4 \cdot 76$
\end{tabular} & $\begin{array}{c}66 \\
55 \cdot 932 \\
4 \cdot 57 \\
-7 \cdot 01 \\
\pm 4 \cdot 90\end{array}$ & $\begin{array}{c}9 \\
7 \cdot 627 \\
2 \cdot 44 \\
+4 \cdot 53 \\
\pm 2 \cdot 53\end{array}$ & $\begin{array}{l}118 \\
100\end{array}$ & \begin{tabular}{c|}
36 \\
$30 \cdot 508$ \\
$4 \cdot 24$ \\
$-8 \cdot 44$ \\
$\pm 4 \cdot 60$
\end{tabular} & $\begin{array}{c}57 \\
48 \cdot 305 \\
4 \cdot 60 \\
-0 \cdot 62 \\
\pm 4 \cdot 95\end{array}$ & $\begin{array}{c}25 \\
21 \cdot 186 \\
3 \cdot 76 \\
+9 \cdot 06 \\
\pm 3 \cdot 95\end{array}$ & $\begin{array}{l}118 \\
100\end{array}$ \\
\hline
\end{tabular}

* Difference exceeds twice its standard error.

an observation which may be explained by the reduction in the period of physiological infertility resulting from the higher incidence of abortions. Secondly, incidence of first births and of malformations was higher in the earlier years of the eight-year period from which this series is drawn. Since controls were selected as a constant proportion

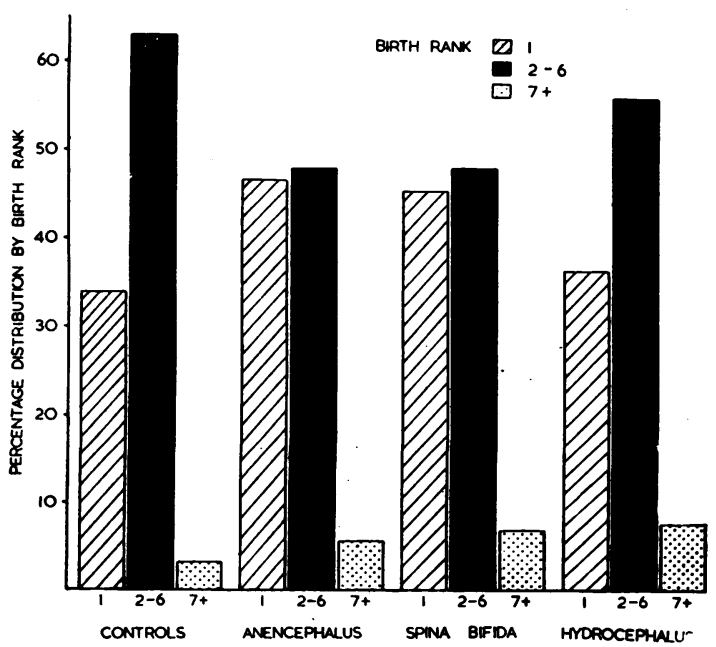

Fig. 9.-Distribution of central nervous malformations by birth rank. of all births in each year, it is possible that the sample is weighted in respect of parity against the controls. Table XXXIII (p. 207) gives the percentages of births in different birth ranks by year, and indicates that in all years except 1940 the proportions of propositi of first birth ranks and above the sixth are consistently higher in the malformation series. The exception in 1940 is explained by the high incidence of untraced first births in the malformations.

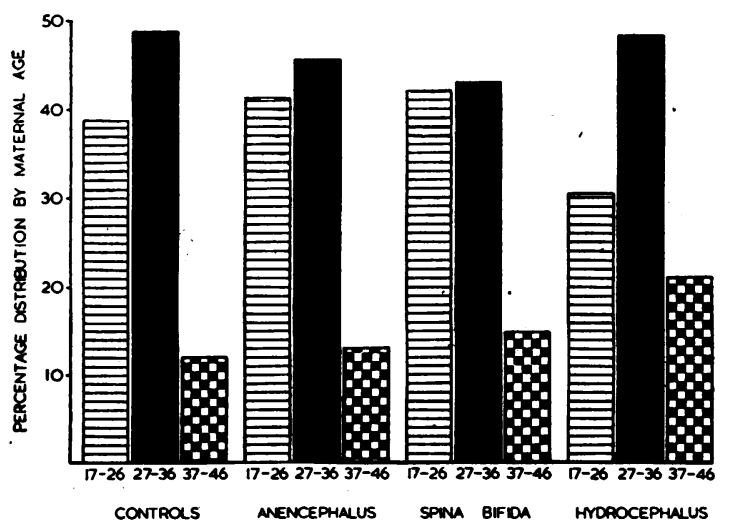

Fig. 10.-Distribution of central nervous malformations by maternal age. 
TABLE XXXI

Mothers of the Malformation and Control Births COMPARED IN ReSPECT OF THE Number of Pregnancies

\begin{tabular}{|c|c|c|c|c|}
\hline \multirow{2}{*}{$\begin{array}{l}\text { Number of } \\
\text { Pregnancies }\end{array}$} & \multicolumn{2}{|c|}{$\begin{array}{l}\text { Malformations } \\
\text { Group }\end{array}$} & \multicolumn{2}{|c|}{ Control Group } \\
\hline & Number & $\begin{array}{c}\text { Per- } \\
\text { centage }\end{array}$ & Number & $\begin{array}{c}\text { Per- } \\
\text { centage }\end{array}$ \\
\hline 1 & 130 & $17 \cdot 22$ & 147 & $19 \cdot 81$ \\
\hline 2 & 208 & $27 \cdot 55$ & 232 & $31 \cdot 27$ \\
\hline 3 & 172 & $22 \cdot 78$ & 146 & $19 \cdot 68$ \\
\hline 4 & 95 & $12 \cdot 58$ & 96 & $12 \cdot 94$ \\
\hline 5 & 54 & $7 \cdot 15$ & 57 & $7 \cdot 68$ \\
\hline 6 & 36 & $4 \cdot 77$ & 30 & $4 \cdot 04$ \\
\hline 7 & 13 & $1 \cdot 72$ & 11 & $1 \cdot 48$ \\
\hline 8 & 13 & 1.72 & 11 & 1.48 \\
\hline 9 & 9 & $1 \cdot 19$ & 4 & 0.54 \\
\hline 10 & 11 & 1.46 & - & -_ \\
\hline 11 & 5 & $0 \cdot 66$ & 5 & 0.67 \\
\hline 12 & 4 & 0.53 & 1 & 0.13 \\
\hline 13 & 3 & $0 \cdot 40$ & - & - \\
\hline 14 & 2 & $0 \cdot 26$ & 1 & 0.13 \\
\hline 15 & $\ldots$ & - & - & - \\
\hline 16 & - & & - & - \\
\hline 17 & - & - & 1 & 0.13 \\
\hline Total & 755 & $100 \cdot 0$ & 742 & $100 \cdot 0$ \\
\hline $\begin{array}{l}\text { Mean num- } \\
\text { ber of preg- } \\
\text { nancies }\end{array}$ & \multicolumn{2}{|c|}{$3 \cdot 29$ (S.D. $2 \cdot 27)$} & \multicolumn{2}{|c|}{$2 \cdot 96$ (S.D. 1.92) } \\
\hline Difference & \multicolumn{4}{|c|}{$0 \cdot 33 \cdot 0 \cdot 11$} \\
\hline
\end{tabular}

TABLE XXXII

Stillbirths With ANencephalus Distributed By Maternal Age Group and Birth Rank in Scotland 0 (1939-1945)

\begin{tabular}{l|l|l} 
Distribution & $\begin{array}{c}\text { Number of } \\
\text { Births }\end{array}$ & $\begin{array}{c}\text { Stillbirths } \\
\text { due to } \\
\text { anencephalus anencephalus }\end{array}$
\end{tabular}

Maternal Age Group $<20$

$\quad 155,520$

25-29 182,238

30-34 146,609

$35-39 \quad 87,683$

$40+$

Not stated

28,301

2,325

Total

631,269

1,672

$2 \cdot 649$

Birth Rank

\begin{tabular}{|c|c|c|c|}
\hline Dorth אank & 221,943 & 558 & \\
\hline 2 & 143,031 & 313 & $2 \cdot 188$ \\
\hline 3 & 82,286 & 227 & $2 \cdot 759$ \\
\hline 4 & 49,390 & 157 & $3 \cdot 179$ \\
\hline $5 \& 6$ & 51,671 & 181 & $3 \cdot 503$ \\
\hline $7+$ & 37.728 & 136 & $3 \cdot 605$ \\
\hline Not stated & 11 & - & - \\
\hline Total & 586,060 & 1,572 & $2 \cdot 682$ \\
\hline
\end{tabular}

CONTROLS

MALFORMATIONS

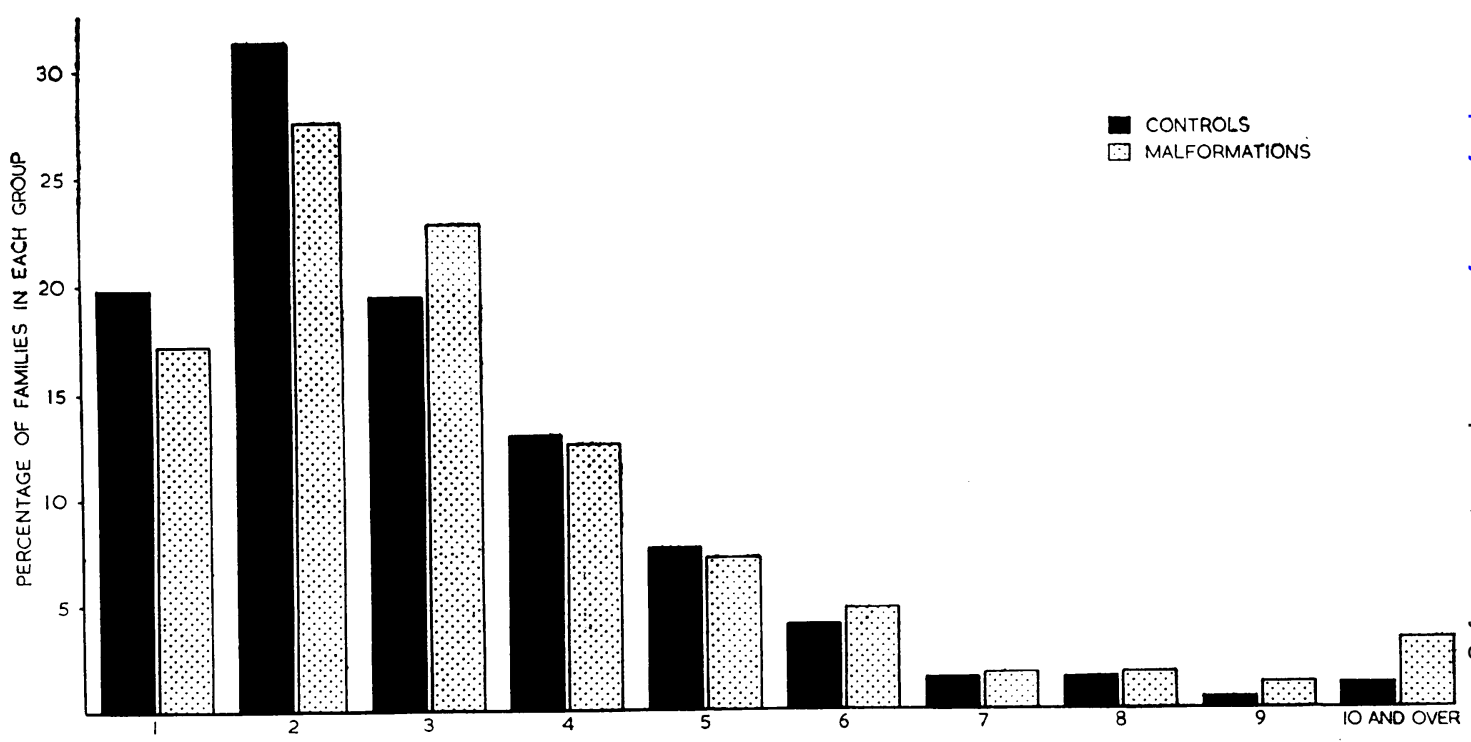

Fig. 11.-Mothers of malformations and control births compared in respect of the number of pregnancies. 
TABLE XXXIII

Percentage Distribution of Propositi by Birth Rank for each Year

\begin{tabular}{|c|c|c|c|c|c|c|c|c|c|c|}
\hline \multirow{2}{*}{\multicolumn{2}{|c|}{ Birth Rank }} & \multicolumn{8}{|c|}{ Year } & \multirow{2}{*}{ All Years } \\
\hline & & 1940 & 1941 & 1942 & 1943. & 1944 & 1945 & 1946 & 1947 & \\
\hline $\begin{array}{c}\text { Malformations } \\
1 \text {. } \\
2 \text { and } 3 \\
4,5 \text { and } 6 \\
7+ \\
\text { Not found }\end{array}$ & $\begin{array}{l}\ddot{.} \\
\ddot{*} \\
\cdots \\
. .\end{array}$ & $\begin{array}{r}23 \cdot 8 \\
24 \cdot 6 \\
9 \cdot 8 \\
6 \cdot 6 \\
35 \cdot 2\end{array}$ & $\begin{array}{r}42 \cdot 1 \\
17 \cdot 9 \\
13 \cdot 7 \\
5 \cdot 3 \\
21 \cdot 1\end{array}$ & $\begin{array}{r}41 \cdot 7 \\
24 \cdot 4 \\
7 \cdot 1 \\
7 \cdot 9 \\
18 \cdot 9\end{array}$ & $\begin{array}{r}-37 \cdot 2 \\
29 \cdot 5 \\
9 \cdot 3 \\
5 \cdot 4 \\
18 \cdot 6\end{array}$ & $\begin{array}{r}39 \cdot 0 \\
29 \cdot 3 \\
9 \cdot 8 \\
4 \cdot 1 \\
17 \cdot 9\end{array}$ & $\begin{array}{r}29 \cdot 3 \\
35 \cdot 4 \\
12 \cdot 1 \\
2 \cdot 0 \\
21 \cdot 2\end{array}$ & $\begin{array}{r}37 \cdot 1 \\
28 \cdot 2 \\
17 \cdot 7 \\
5 \cdot 6 \\
11 \cdot 3\end{array}$ & $\begin{array}{r}36 \cdot 9 \\
37 \cdot 8 \\
15 \cdot 3 \\
3 \cdot 6 \\
6 \cdot 3\end{array}$ & $\begin{array}{r}35 \cdot 9 \\
28 \cdot 4 \\
11 \cdot 7 \\
5 \cdot 2 \\
18 \cdot 8\end{array}$ \\
\hline Total & .. & 100 & 100 & 100 & 100 & 100 & 100 & 100 & 100 & $100 \cdot 0$ \\
\hline $\begin{array}{l}\text { Controls } \\
\begin{array}{l}1 \text {. } \\
2 \text { and } 3 \\
4,5 \text { and } 6 \\
7+ \\
\text { Not found }\end{array}\end{array}$ & $\begin{array}{l}. \\
\cdots \\
\ddot{.} \\
.\end{array}$ & $\begin{array}{r}29 \cdot 2 \\
27 \cdot 1 \\
15 \cdot 6 \\
4 \cdot 2 \\
24 \cdot 0\end{array}$ & $\begin{array}{r}31 \cdot 9 \\
25 \cdot 3 \\
16 \cdot 5 \\
5 \cdot 5 \\
20 \cdot 9\end{array}$ & $\begin{array}{r}36 \cdot 9 \\
32 \cdot 0 \\
14 \cdot 6 \\
1 \cdot 0 \\
15 \cdot 5\end{array}$ & $\begin{array}{r}33 \cdot 0 \\
36 \cdot 7 \\
12 \cdot 8 \\
1 \cdot 8 \\
15 \cdot 6\end{array}$ & $\begin{array}{r}23 \cdot 4 \\
42 \cdot 7 \\
17 \cdot 7 \\
1 \cdot 6 \\
14 \cdot 5\end{array}$ & $\begin{array}{r}21 \cdot 3 \\
41 \cdot 7 \\
15 \cdot 7 \\
1 \cdot 9 \\
19 \cdot 4\end{array}$ & $\begin{array}{r}25 \cdot 4 \\
43 \cdot 9 \\
14 \cdot 0 \\
4 \cdot 4 \\
12 \cdot 3\end{array}$ & $\begin{array}{r}30 \cdot 5 \\
47 \cdot 3 \\
16 \cdot 0 \\
1 \cdot 5 \\
4 \cdot 6\end{array}$ & $\begin{array}{l}28 \cdot 8 \\
37 \cdot 9 \\
15 \cdot 4 \\
2 \cdot 6 \\
15 \cdot 3\end{array}$ \\
\hline Total & .. & 100 & 100 & 100 & 100 & 100 & 100 & 100 & 100 & $100 \cdot 0$ \\
\hline $\begin{array}{l}\text { Percentages of Birth } \\
\text { In malformation } \\
\text { series } \\
\text { In control series }\end{array}$ & $\begin{array}{c}\text { Ran } \\
\text { n } \\
\text {. }\end{array}$ & $\begin{array}{r}n k s \text { an } \\
30 \cdot 4 \\
33 \cdot 4\end{array}$ & $\begin{array}{l}47 \cdot 4 \\
37 \cdot 4\end{array}$ & $\begin{array}{l}49 \cdot 6 \\
37 \cdot 9\end{array}$ & $\begin{array}{l}42 \cdot 6 \\
34 \cdot 8\end{array}$ & $\begin{array}{l}43 \cdot 1 \\
25 \cdot 0\end{array}$ & $\begin{array}{l}31 \cdot 3 \\
23 \cdot 2\end{array}$ & $\begin{array}{l}42 \cdot 7 \\
29 \cdot 8\end{array}$ & $\begin{array}{l}40 \cdot 5 \\
32 \cdot 0\end{array}$ & $\begin{array}{l}41 \cdot 1 \\
31 \cdot 4\end{array}$ \\
\hline Difference & & $-3 \cdot 0$ & $10 \cdot 0$ & $11 \cdot 7$ & $7 \cdot 8$ & $18 \cdot 1$ & $8 \cdot 1$ & $12 \cdot 9$ & $8 \cdot 5$ & $9 \cdot 7$ \\
\hline
\end{tabular}

DATA DERIVED FROM THE REPORTS OF THE RegistraR-GeNERAL FOR SCOTLAND (1939-1945).The reports of the Registrar-General for Scotland since 1939 give for stillbirths the age of the mother and the number of previous children. The same information is not provided for infant deaths, and the effects of age and parity can only be examined for anencephalus which almost always results in the birth of a stillborn foetus. The figures given in Table XXXII (opposite) for the years 1939-1945 show the increased risks observed in the Birmingham data, but relatively the effects at higher ages and parities are much greater (Fig. 12). The two sets of data are not strictly comparable, for the Scottish figures are based only on legitimate births, and the RegistrarGeneral neglects abortions in estimating parity. The higher incidence of -abortions in mothers of malformations is certain to influence birth rank. Unfortunately, the Scottish data do not enable us to examine separately the effects of maternal age and parity.

Discussion.-The relation of maternal age and parity to the incidence of congenital malformations has been considered by several writers, but adequate data on malformations and controls have not been available, and no evidence so far published settles the issue beyond doubt. Still (1927) first compared a small number of malformations with an unsatisfactory control group, and concluded that risks were higher with first born, particularly in the case

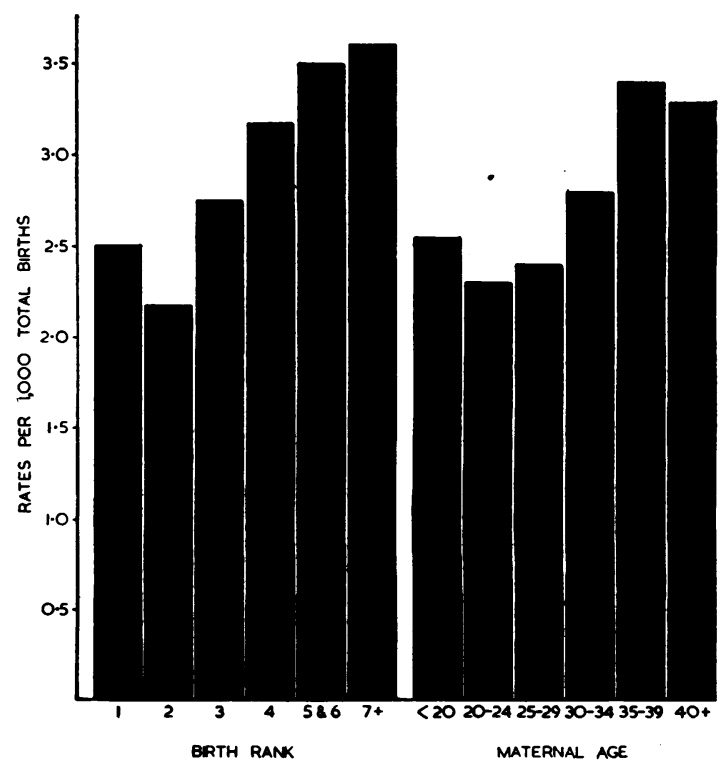

Fig. 12.-Stillbirth rates due to anencephalus distributed by birth rank and maternal age (Scotland, 1939-45). 
of pyloric stenosis. In the case of mongolism, however, the risk appeared to be greater at high maternal age. His results were criticized by Macklin (1929) who examined statistics on 1,000 malformations collected from the literature, and decided that primogeniture had no effect. Equally unsatisfactory are reports based on hospital records, in which the numbers are small and the populations unrepresentative. (Malpas, 1937; Potter and Adair, 1943; Drillien, 1947.)

Murphy (1940) completed a field study of malformations selected from the register of deaths in Philadelphia, and using the Greenwood-Yule method compared the malformations with the non-malformed children of the same sibships. He noted that the risk of birth of a malformation increased with both age and parity, but did not separate the two effects. In this series, many of the sibships were incomplete at the time of the investigation which was finished within six years of the first death and less than one year after the last, and the control group was therefore likely to be deficient in the higher birth ranks and maternal ages. Data published by Hindse-Nielsen (1938) on 160 cases of spina bifida in 130 families permit an examination of the association with birth rank, which shows that this malformation was slightly less frequent in the first three birth ranks. Once again there is no indication that the sibships were complete at the time the data were recorded.
The most useful contribution yet available on this? subject was made by Penrose $(1934 ; 1946)$. In the first of two papers he showed that the risk of mongolism increased with advancing maternal age the effect of birth rank was less marked, but thoo first born and infants of high birth rank seemedo predisposed to the condition. His second paper $\frac{\bar{s}}{5}$. dealt with 144 malformations of the nervous system,, and, using a modification of the Greenwood-Yulen method, he found that their incidence increased. significantly with advancing maternal age and with rising birth rank. The effect of maternal age appeared to be more marked than that of birtho rank, although when the influence of maternal age was eliminated, primogeniture still seemed to increase the risk. The discrepancy between Pen ${ }_{+}^{-\omega}$ rose's results and our own may be explained by the higher proportion of hydrocephalics in his seriesw. (31 per cent. compared with 16 per cent.) for, as we? have shown, the incidence of hydrocephalus is markedly increased at higher maternal ages.

\section{Social Status}

Indices of social status used are: locality of domicile; rent of house; and legitimacy. Thet father's occupation was also recorded, but is 皿 considered sufficiently reliable for analysis.

LoCALITY of Domicile.-Appendix A describes 20 classification of the city wards into three sociab

TABLE XXXIV

Malformations Classified by Ward Groups

\begin{tabular}{|c|c|c|c|c|c|c|c|c|c|}
\hline \multirow{3}{*}{ Type of Malformation } & \multicolumn{6}{|c|}{ Ward Group* } & \multirow{3}{*}{ Unlocated } & \multirow{2}{*}{\multicolumn{2}{|c|}{ All Wards }} \\
\hline & \multicolumn{2}{|r|}{$\mathbf{I}$} & \multicolumn{2}{|r|}{ II } & \multicolumn{2}{|r|}{ III } & & & \\
\hline & No. & $\begin{array}{c}\text { Rates per } \\
1,000 \\
\text { related } \\
\text { Births }\end{array}$ & No. & $\begin{array}{l}\text { Rates per } \\
1,000 \\
\text { related } \\
\text { Births }\end{array}$ & No. & $\begin{array}{l}\text { Rates per } \\
1,000 \\
\text { related } \\
\text { Births }\end{array}$ & & No. & $\begin{array}{c}\text { Rates per } \\
1,000 \\
\text { related } \\
\text { Births }\end{array}$ \\
\hline 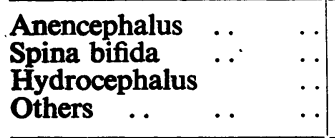 & $\begin{array}{r}121 \\
136 \\
63 \\
6\end{array}$ & $\begin{array}{l}2 \cdot 135 \\
2 \cdot 400 \\
1 \cdot 112 \\
0 \cdot 106\end{array}$ & $\begin{array}{r}170 \\
179 \\
61 \\
11\end{array}$ & $\begin{array}{l}2 \cdot 361 \\
2 \cdot 486 \\
0 \cdot 847 \\
0 \cdot 153\end{array}$ & $\begin{array}{r}75 \\
73 \\
26 \\
8\end{array}$ & $\begin{array}{l}2 \cdot 535 \\
2 \cdot 468 \\
0 \cdot 879 \\
0 \cdot 270\end{array}$ & $\frac{-}{-}$ & $\begin{array}{r}366 \\
389 \\
150 \\
25\end{array}$ & $\begin{array}{l}2 \cdot 312 \\
2 \cdot 457 \\
0 \cdot 948 \\
0 \cdot 158\end{array}$ \\
\hline All malformations & 326 & $5 \cdot 753$ & 421 & $5 \cdot 847$ & 182 & $6 \cdot 152$ & 1 & 930 & $5 \cdot 875$ \\
\hline 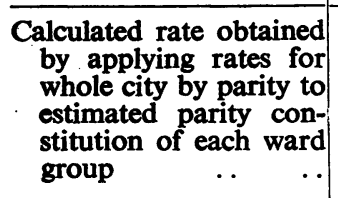 & - & $5 \cdot 756$ & - & $5 \cdot 833$ & - & $6 \cdot 156$ & - & - & - \\
\hline
\end{tabular}




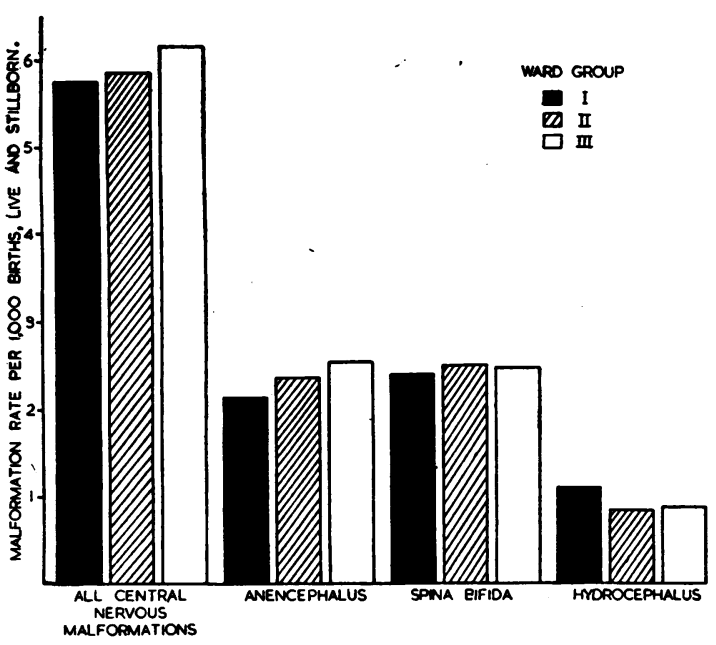

Fig. 13.-Malformation rates by ward groups (Birmingham, 1940-47).

groups, and the home address of the mother at the time of the birth was used to place each malformation in one of them. Table XXXIV gives for each group the number of malformations of the three main types, and rates have been calculated from the total births (live and stillborn) in each ward group of the city for the same period, births within the city to women normally domiciled outside being excluded. (See Fig. 13.)
TABLE XXXV

The Proportion of Stillborn Malformations CLASSIFIED BY WARD GROUPS

\begin{tabular}{|c|c|c|c|c|}
\hline \multirow{2}{*}{ Malformations } & \multicolumn{3}{|c|}{ Ward Group } & \multirow{2}{*}{$\begin{array}{c}\text { All } \\
\text { Wards }\end{array}$} \\
\hline & I & II & III & \\
\hline $\begin{array}{l}\text { Stillborn } \\
\text { Died in first year }\end{array}$ & $\begin{array}{l}204 \\
122\end{array}$ & $\begin{array}{l}262 \\
159\end{array}$ & $\begin{array}{r}117 \\
65\end{array}$ & $\begin{array}{l}583 \\
346\end{array}$ \\
\hline Total & 326 & 421 & 182 & 929 \\
\hline $\begin{array}{c}\text { Percentage still- } \\
\text { born } \ldots\end{array}$ & $62 \cdot 6$ & $62 \cdot 2$ & $64 \cdot 3$ & $62 \cdot 8$ \\
\hline
\end{tabular}

TABLE XXXVI

The Proportion of Stillborn Malformations CLASSIFIED BY WARD GROUPS (ANENCEPHAL US EXCLUDED)

\begin{tabular}{|c|c|c|c|c|}
\hline \multirow{2}{*}{ Malformations } & \multicolumn{3}{|c|}{ Ward Group } & \multirow{2}{*}{$\underset{\text { Wards }}{\text { All }}$} \\
\hline & I & II & III & \\
\hline $\begin{array}{l}\text { Stillborn } \\
\text { Died in first year }\end{array}$ & $\begin{array}{r}90 \\
115\end{array}$ & $\begin{array}{l}101 \\
150\end{array}$ & $\begin{array}{l}45 \\
62\end{array}$ & $\begin{array}{l}236 \\
327\end{array}$ \\
\hline Total & 205 & 251 & 107 & 563 \\
\hline $\begin{array}{c}\text { Percentage still- } \\
\text { born }\end{array}$ & 43.9 & $40 \cdot 2$ & $42 \cdot 1$ & $41 \cdot 9$ \\
\hline
\end{tabular}

TABLE XXXVII

Malformation and Control Groups compared in Relation to Rent of House

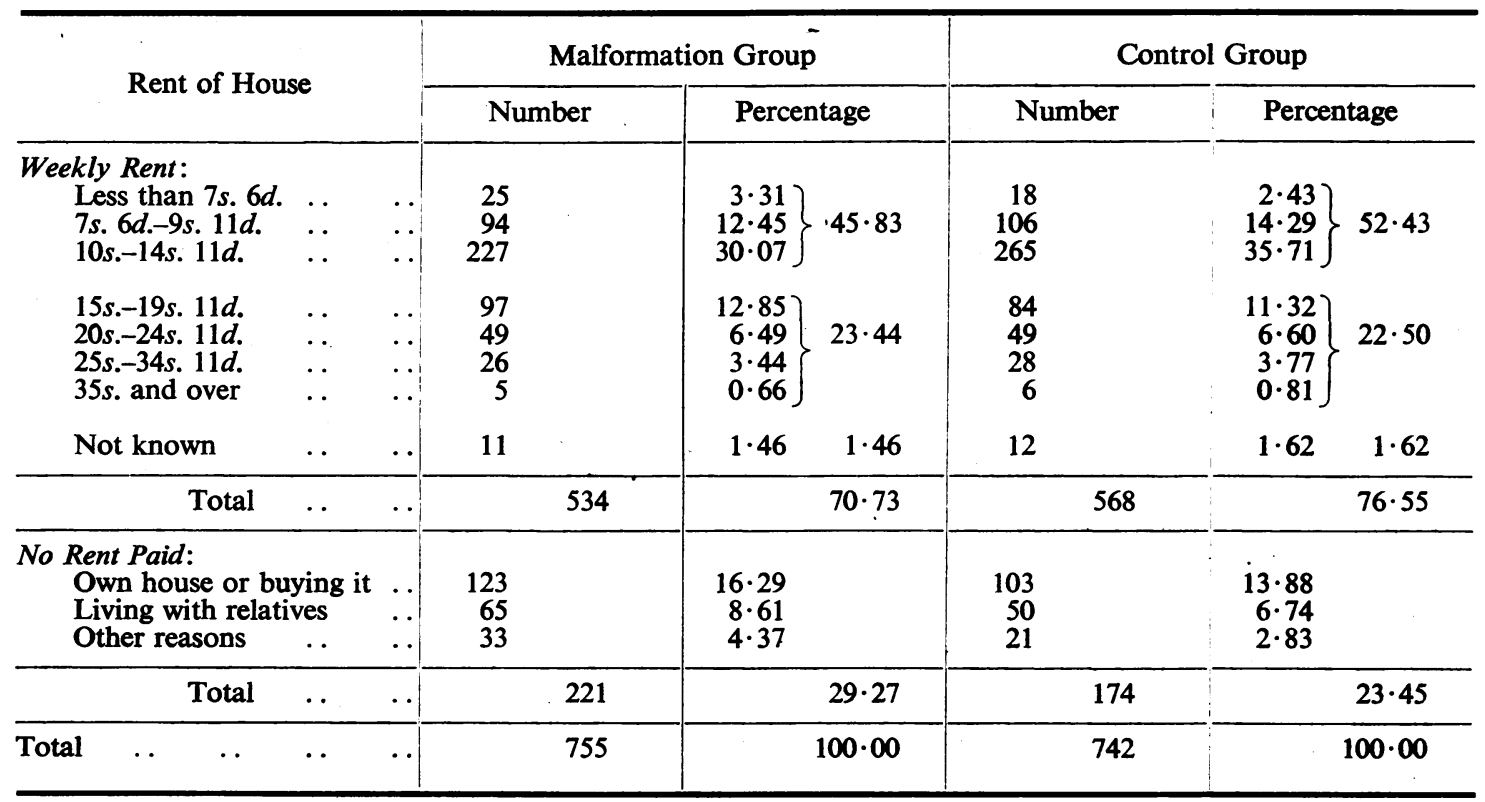


The rate for anencephalus is slightly higher in the better ward groups, but the numbers are not large enough to be more than suggestive. The proportions of malformations which were stillborn are given in Table XXXV for the three ward groups; the figure is slightly higher in the third. This group, however, contains a higher proportion of anencephalus, and when this type is excluded (Table XXXVI) there is little difference between the three groups.

Since the risk of malformation is related to birth rank, comparison between ward groups is not satisfactory unless the rates are standardized for parity. Applying the city malformation rates for each birth rank to the population of each ward group estimated from the control series, we obtained a malformation rate per ward group almost identical with the observed rate which suggests that the increased rate in the better wards is due to the increased proportion of primiparae in these wards. This result, however, must be accepted with reserve because of the rather high proportion of cases of unknown birth rank (ward group I, 16 per cent.; ward group II, 12 per cent.; ward group III, 19 per cent.).
RENT OF House.-The rent of the house was obtained in the field enquiry, and is used in Table XXXVII as the basis of a comparison between the malformation and control groups. In the malformation group the percentage in houses rented at less than 15s. per week is $6.60( \pm 2.58)$ lower than the percentage in the control series.

LEGITIMACY.-The civil status of the malformations was obtained from Maternity and Child Welfare Department records, and Table XXXVIII compares the proportion illegitimate with the corresponding figure for all births in Birmingham of the same period. The proportion of malformations which were illegitimate is low in consequence mainly of the contribution of anencephalus. The high proportion of stillbirths characteristic of this type of malformation could account for the difference, if there were evidence of less accurate reporting of civil status for stillbirths. This possibility is examined in Table XXXIX, which gives the proportion of illegitimate births for stillborn and live born malformations of the nervous system, with anencephalus excluded. The figures do not suggest that stillbirths are less accurately reported, and the low

TABLE XXXVIII

Civil Status of Malformations

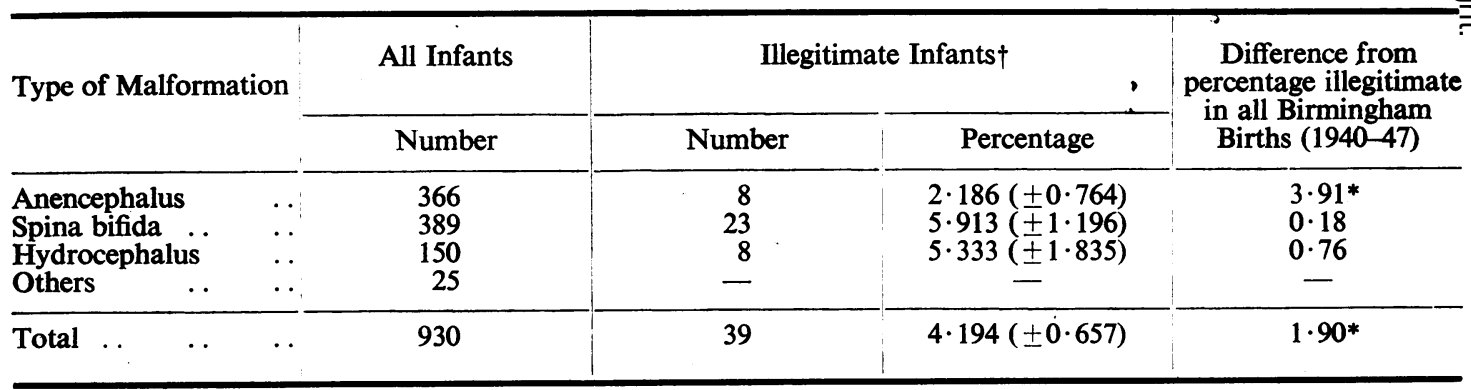

* Difference exceeds twice its standard error.

t Illegitimacy rate for live and still births for Birmingham (1940-1947): 6.096 per 100. (Registrar-General.)

TABLE XXXIX

The Proportion of Illegitimate Births for Stillborn and Live-Born Malformations (ANencephal us eXCluded)

\begin{tabular}{|c|c|c|c|c|}
\hline \multirow{2}{*}{ Type of Malformation } & \multicolumn{2}{|c|}{ Stillborn } & \multicolumn{2}{|c|}{ Infant Deaths } \\
\hline & Illegitimate & $\begin{array}{l}\text { Legitimate and } \\
\text { Illegitimate }\end{array}$ & Illegitimate & $\begin{array}{l}\text { Legitimatè and } \\
\text { Illegitimate }\end{array}$ \\
\hline $\begin{array}{ll}\text { Spina bifida . } & \ldots \\
\text { Hydrocephalus } & \ldots \\
\text { Others } & \text {. }\end{array}$ & $\begin{array}{r}9 \\
6 \\
-\end{array}$ & $\begin{array}{r}120 \\
112 \\
5\end{array}$ & $\begin{array}{r}14 \\
2 \\
-\end{array}$ & $\begin{array}{r}269 \\
38 \\
20\end{array}$ \\
\hline $\begin{array}{ll}\ldots & \ldots\end{array}$ & 15 & 237 & 16 & 327 \\
\hline $\begin{array}{l}\text { Illegitimate as Percen- } \\
\text { tage of Total }\end{array}$ & & & & \\
\hline
\end{tabular}


TABLE XL

Legitimacy of Stillbirths due to Malformations of the Nervous System and of INfant Deaths due to all CoNGentTal Malformations In Scotland (1939-1945)

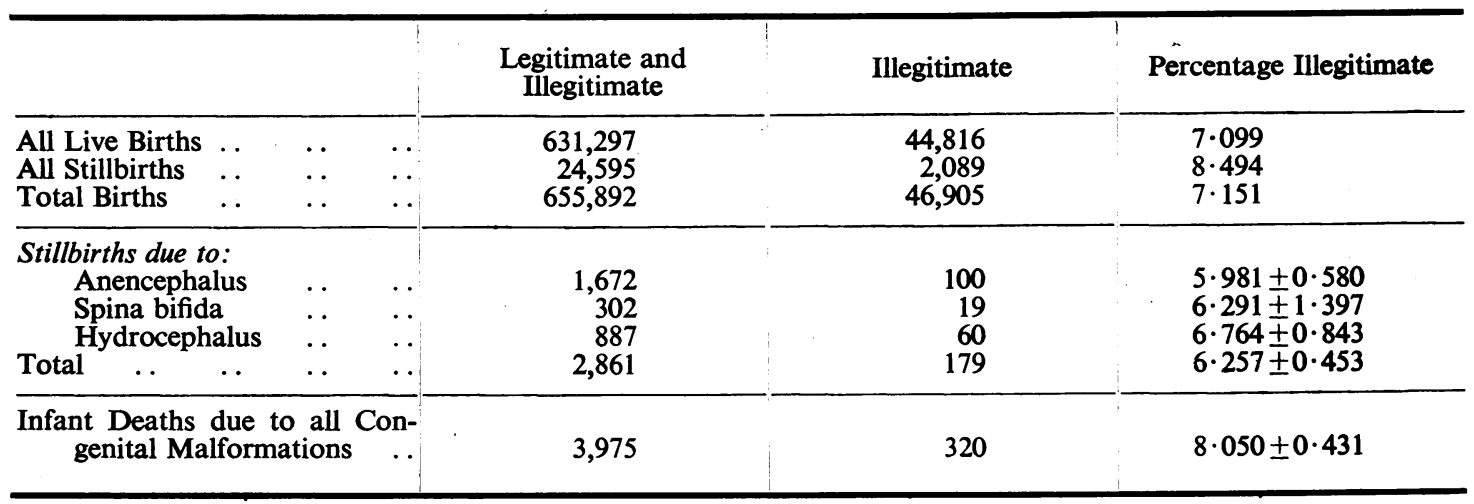

illegitimate rate for anencephalus appears to be independent of this factor.

The annual reports of the Registrar-General for Scotland for the years' $1939-1945$ record the civil status of stillbirths for anencephalus, spina bifida and hydrocephalus, and the civil status of infant deaths for all congenital malformations grouped together (Table XL). Only anencephalus can be compared with our tables, which combine stillbirths and infant deaths. Although the proportion of illegitimate births among the anencephalics in the Scottish data is considerably higher than in the Birmingham series, it is nevertheless below the proportion for all Scottish births.

Discussion.-The Registrar-General (Decennial Supplement, 1921) suggested that social class had little effect on infant mortality from congenital malformations, a conclusion supported by Woolf (1946) from statistics for England and Wales (Table XLI). Murphy (1940) found a low proportion of well-to-do families among those from which 571 malformations were drawn, and noted that in a hospital for poor patients the incidence of malformations was twice as great as the rate for the whole city (Philadelphia). On this not very satisfactory evidence he concluded that mothers in poor social circumstances were exposed to an increased risk of the birth of a malformation; evidence in support of this view was provided by Baird (1947) who compared the numbers of malformations in two small series of births selected from private and hospital practice. These reports examine the relation of social class to the incidence of all malformations; the literature contains no information on its relation to the incidence of different types of malformation.
TABLE XLI

INFANT MORTALITY RATE ATtRIBUtable to CONGENITAL MALFORMATIONS bY SOCIAL ClasS OF FATHER-ENGLAND AND WALES, 1930-1932. (QUOTED BY WOOLF, 1946)

\begin{tabular}{l|c|c|c|c|c|c}
\hline Social Class & I & II & III & IV & V & All \\
\hline $\begin{array}{l}\text { Infant mortality } \\
\text { rate per 1,000 }\end{array}$ & 5.0 & 5.4 & 5.6 & 5.7 & 5.4 & 5.5 \\
\hline
\end{tabular}

The influence of the nutritional state of the mother on the risk of malformations has been considered in animals (Hale, 1933; Warkany, 1945, etc.). Certainly severe vitamin deficiencies do result in the occurrence of congenital malformations of a special type in a proportion of the young of selected experimental animals, though the relation of this fact to the human problem is uncertain. There is no laboratory evidence that central nervous malformations, numerically the largest group in human beings, are produced in this way. Murphy (1940) and Burke and others (1933) inspected the dietary habits of pregnant women, and concluded that poor diets were common among mothers who delivered malformed births. The conclusions in both cases are based on small numbers of observations and are influenced by the difficulties familiar to investigators of human dietary habits. Diet is, of course, only one of the variables related to social status.

\section{Maternal Health during Pregnancy}

Information about maternal health during pregnancy was obtained for the malformation and control series, by direct interrogation of the mothers. Its reliability is difficult to assess, not only because any patient's memory of her own illness is subject 
TABLE XIII

Disability during Pregnancy

\begin{tabular}{|c|c|c|c|c|c|c|c|c|c|c|c|c|}
\hline \multirow{3}{*}{ Disability } & \multicolumn{10}{|c|}{ Type of Malformation } & \multirow{2}{*}{\multicolumn{2}{|c|}{$\begin{array}{c}\text { Controls } \\
(742)^{*}\end{array}$}} \\
\hline & \multicolumn{2}{|c|}{$\begin{array}{c}\text { Anencephalus } \\
(305)^{*}\end{array}$} & \multicolumn{2}{|c|}{$\begin{array}{c}\text { Spina bifida } \\
(309)^{*}\end{array}$} & \multicolumn{2}{|c|}{$\begin{array}{c}\text { Hydrocephalus } \\
\text { (118)* }\end{array}$} & \multicolumn{2}{|c|}{$\begin{array}{l}\text { Others } \\
(23)^{*}\end{array}$} & \multicolumn{2}{|c|}{$\begin{array}{l}\text { Total } \\
(755)^{*}\end{array}$} & & \\
\hline & No. & $\%$ & No. & $\%$ & No. & $\%$ & No. & $\%$ & No. & $\%$ & No. & $\%$ \\
\hline $\begin{array}{l}\text { First half of Pregnancy } \\
\text { Vomiting of pregnancy ... } \\
\text { Threatened abortion } \\
\text { Severe mental shock } \\
\text { Falls and minor accidents } \\
\text { Surgical operations } \\
\text { Other major conditions ... }\end{array}$ & $\begin{array}{l}28 \\
11 \\
3 \\
4 \\
1 a \\
1 e\end{array}$ & $\begin{array}{l}9 \cdot 2 \\
3 \cdot 6 \\
1 \cdot 0 \\
1 \cdot 3 \\
0 \cdot 3 \\
0 \cdot 3\end{array}$ & $\begin{array}{c}20 \\
6 \\
4 \\
4 \\
1 b \\
-\end{array}$ & $\begin{array}{l}6 \cdot 5 \\
1 \cdot 9 \\
1 \cdot 3 \\
1 \cdot 3 \\
0 \cdot 3 \\
-\end{array}$ & $\begin{array}{l}3 \\
1 \\
1 \\
1 c \\
3 f\end{array}$ & $\begin{array}{l}2 \cdot 5 \\
0 \cdot 8 \\
\overline{0 \cdot 8} \\
0 \cdot 8 \\
2 \cdot 5\end{array}$ & $\begin{array}{l}1 \\
1 \\
- \\
-\end{array}$ & $\begin{array}{l}4 \cdot 3 \\
4 \cdot 3 \\
= \\
= \\
=\end{array}$ & $\begin{array}{r}52 \\
19 \\
7 \\
9 \\
3 \\
4\end{array}$ & $\begin{array}{l}6 \cdot 9 \\
2 \cdot 5 \\
0 \cdot 9 \\
1 \cdot 2 \\
0 \cdot 4 \\
0 \cdot 5\end{array}$ & $\begin{array}{r}37 \\
8 \\
2 \\
1 d \\
1 g\end{array}$ & $\begin{array}{l}5 \cdot 0 \\
1 \cdot 1 \\
0 \cdot 3 \\
\overline{0 \cdot 1} \\
0 \cdot 1\end{array}$ \\
\hline 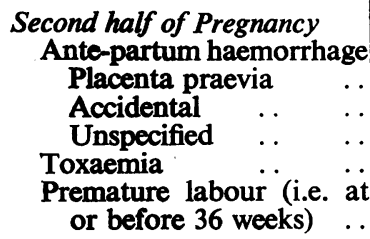 & $\begin{array}{r}3 \\
2 \\
2 \\
15 \\
196\end{array}$ & $\begin{array}{r}1 \cdot 0 \\
0 \cdot 7 \\
0 \cdot 7 \\
4 \cdot 9 \\
64 \cdot 3\end{array}$ & $\frac{\overline{1}}{12}$ & $\begin{array}{l}\overline{0 \cdot 3} \\
\frac{3 \cdot 9}{16 \cdot 2}\end{array}$ & $\frac{-}{10}$ & $\begin{array}{l}\bar{Z} \\
\overline{8 \cdot 5} \\
21 \cdot 2\end{array}$ & $\begin{array}{c}\overline{-} \\
\frac{1}{3}\end{array}$ & $\begin{array}{c}\bar{Z} \\
\overrightarrow{4 \cdot 3} \\
13 \cdot 0\end{array}$ & $\begin{array}{r}3 \\
3 \\
2 \\
38 \\
274\end{array}$ & $\begin{array}{r}0.4 \\
0 \cdot 4 \\
0 \cdot 3 \\
5 \cdot 0 \\
\\
36 \cdot 3\end{array}$ & $\begin{array}{l}\frac{-}{\overline{38}} \\
60\end{array}$ & $\overline{-}$ \\
\hline
\end{tabular}

to error, but also because it is not unlikely that mothers readily recall details of a pregnancy which resulted in an abnormal birth, whereas details after normal deliveries are quickly forgotten. For example, falls and minor accidents were recorded nine times in association with the malformations, and not at all in the control series. With these difficulties in mind we may consider the data for both groups in Table XLII.

THREATENED ABORTION.-Threatened abortion was slightly more common in pregnancies which resulted in anencephalics than in those associated with other central nervous malformations or with normal births. With the exception of one case in which the mother admitted that she attempted to induce an abortion, we have no information about the cause, the facts being equally consistent with the threatened abortion of an abnormal embryo, or with defective implantation resulting in embryonic defect. In either case, the figures do not recommend this as a common contribution to the aetiology of central nervous malformation. The literature offers few results for comparison, but the report by Shute (1939) of 2 per cent. of deformed foetuses in 443 cases of threatened abortion treated with vitamin $\mathrm{E}$ or progesterone, ${ }^{*}$ is consistent with this view. Kotz, Parker, and Kaufman (1941) published

* A series collected from the literature. details of 184 cases of threatened abortion, associ ated with the birth of 102 viable infants; abnormali ties were recorded in five cases $(4.9$ per cent.) and of these only two (anencephalus and mongo lism) were of a major type. In further support of this view may be cited the fact (detailed in the previous section) that illegitimate pregnancies, which almost certainly experience attempts at interference more frequently than legitimate pregnancies, do not show a greater incidence of malformations.

Placenta Praevia.-Placenta praevia existed in three out of 305 cases of anencephalus, and in none of the other malformations or normal births. This proportion ( 1 per cent.) is about ten times greater than that usually given for all births $(0 \cdot 1$ per cent.) and is unlikely to be due to chance. Even so, the majority of anencephalics have a placenta which is normally situated, and the majority of placentae praeviae are associated with normal foetuses. The association of placenta praevia with foetal deformity was first noted by Greenhill (1923), who later (1939) collected from clinic records and from the literature details of 4,446 cases of placenta praevia of which 111 were associated with deformed foetuses $(2.5$ per cent., as compared with 0.94 per cent. in a large series of normal deliveries). Data which confirm this association were recorded by Siegal (1934), Murphy (1940), and Potter and Adair (1943). 
The high incidence of foetal deformities among extra-uterine embryos is well known (Mall, 1917; Hellman and Simon, 1935; Suter and Wichser, 1948), but the relevance of this observation to the malformed foetus which develops within the uterus is in doubt. Furthermore, many of these deformities are of a minor character for which a mechanical explanation may be advanced. On present evidence it is not possible to say whether defective implantation of the ovum per se is or is not a factor of much importance in the aetiology of malformations of the nervous system.

DiABETES Mellitus.-Diabetes occurred only once in the series, and was associated with the birth of a hydrocephalic infant. Skipper (1933) and White (1935) reported 3.0 per cent. and 4.2 per cent. respectively for the incidence of malformations in 169 and 166 pregnancies in diabetic women. Once again the association is noteworthy, but can scarcely be a frequent factor in the causation of malformations. It is probable that the increased incidence can be, to some extent, accounted for by the fact that diabetes is usually associated with a high stillbirth rate, thus rendering available for autopsy an unusually high proportion of foetuses. In this way minor internal malformations which may for a time be undetected in the live born are brought to notice.

TOXAEMIA.- The incidence of toxaemia is about equal in the control and malformation groups. Drillien (1947) reported a lower incidence of toxaemia in pregnancies which resulted in malformations, and certainly this condition, uncommon before the sixth month, would not be expected to influence malformations which are laid down early in pregnancy.

VIRUS INFECTIONS.-There was no history of rubella or of any other virus infection during the pregnancies resulting in 755 malformations of the nervous system; there was also no history of virus infection in the pregnancies of the controls. On this evidence we can neither confirm nor refute the suggested role of these infections in other types of malformations (which mainly exclude those of the central nervous system) but are entitled to conclude that they are not commonly associated. with the malformations here investigated. The earlier observations on the association of rubella with congenital defects have been reviewed by Parsons (1946), Murphy (1947), Warkany and others (1948). Others have attempted to meet the inevitable criticism of retrospective observations on malformed foetuses by noting the incidence of malformations among the births when rubella was recorded during pregnancy (Fox and Bortin, 1946; Ober and others, 1947; and Bradford Hill and Galloway, 1949). The numbers so far obtained in this way are small, but suggest an incidence considerably in excess of experience with normal pregnancies.

Observations on other virus infections in pregnancy have been recorded by Dogramaci and Green (1947), Fox and others (1948), and Gérard-Lefebvre and Merlen (1948), and with one exception (GérardLefebvre and Merlen) gave negative results. Evans and Smith (1946) interrogated mothers who gave birth to 25 lethal malformations, and did not elicit a history of virus disease during pregnancy. Influenza has also been suggested as a causal agent, but our examination of the Registrar-General's returns since 1916 indicates that the malformation rate is not correlated with the annual death rate from influenza of the same or of the previous year.

THERAPEUTIC IRRADIATION OF THE Foetus WITH RADIUM OR $X$ RAYS.-Evidence assembled by Murphy (1947) strongly suggested that malformations, particularly of the nervous system, can result from irradiation of the foetus in utero. No history of irradiation was obtained in the pregnancies which produced the malformed births of our series.

Severe Mental Shock.-Popularly considered a potent factor in producing malformations, severe mental shock was recorded for seven of the malformations, and for two of the controls; for the reason stated at the beginning of this section, little attention can be paid to this slight difference in incidence. It is also worth noting that the incidence of malformations was not higher in the city during the years when air raids were most frequent.

Premature Labour.-Premature labour is mentioned in this context, not because it has any bearing on the aetiology of malformations, but because its common occurrence when the foetus is malformed, especially in cases of anencephalus, is of interest (see Table XLII). As an index of early labour the usual definition of prematurity based on the weight of the foetus would be particularly misleading in a discussion on central nervous malformations, since the abnormal size of the head in many cases has an obvious relation to the infant's weight. Accordingly we have based our statistics on the duration of gestation estimated from the date of the last menstrual period.

Stillborn foetuses with central nervous malformations, are frequently macerated, indicating that death has taken place some time prior to labour, presumably as a result of the malformation. This accounts for a number of the cases of premature 
TABLE XLIII

Employment of Mothers of the Control Group at the Onset of Pregnancy (1940-47)*

\begin{tabular}{|c|c|c|c|c|c|c|c|c|c|}
\hline & \multicolumn{8}{|c|}{ Year of Birth of Propositus } & \multirow{2}{*}{ Total } \\
\hline & 1940 & 1941 & 1942 & 1943 & 1944 & 1945 & 1946 & 1947 & \\
\hline $\begin{array}{l}\text { Primigravidae } \\
\text { Multigravidae } \\
\text { Total } \quad . .\end{array}$ & $\begin{array}{l}28(25 \cdot 0) \\
45(11 \cdot 1) \\
73(16 \cdot 4)\end{array}$ & $\left|\begin{array}{l}29(51 \cdot 7) \\
43(20 \cdot 9) \\
72(33 \cdot 3)\end{array}\right|$ & $\begin{array}{l}38(52 \cdot 6) \\
49(10 \cdot 2) \\
87(28 \cdot 7)\end{array}$ & $\begin{array}{l}36(61 \cdot 1) \\
56(23 \cdot 2) \\
92(38 \cdot 0)\end{array}$ & $\begin{array}{r}29(65 \cdot 5) \\
77(18 \cdot 2) \\
106(31 \cdot 1)\end{array}$ & $\begin{array}{l}23(69 \cdot 6) \\
64(15 \cdot 6) \\
87(29 \cdot 9)\end{array}$ & $\begin{array}{r}29(48 \cdot 3) \\
71(15 \cdot 5) \\
100(25 \cdot 0)\end{array}$ & $\begin{array}{r}40(42 \cdot 5) \\
85(14 \cdot 1) \\
125(23 \cdot 2)\end{array}$ & $\begin{array}{l}252(51 \cdot 6) \\
490(16 \cdot 1) \\
742(28 \cdot 2)\end{array}$ \\
\hline $\begin{array}{l}\text { Nervous Mal- } \\
\text { formation } \\
\text { rate per } \\
1,000 \text { (all } \\
\text { city births) }\end{array}$ & $7 \cdot 43$ & $6 \cdot 55$ & $6 \cdot 98$ & $6 \cdot 48$ & $5 \cdot 52$ & $5 \cdot 03$ & $5 \cdot 46$ & $4 \cdot 52$ & $5 \cdot 87$ \\
\hline
\end{tabular}

* The table gives the total number of women in each group, and, in brackets, the percentage of these employed in a remunerated occupation $\omega$ at the onset of pregnancy.

TABLE XLIV

Comparison between Malformation and Control Groups in Respect of Work of Mothers in Early $\vec{O}$ PREGNANCY

\begin{tabular}{|c|c|c|c|c|c|c|c|c|}
\hline \multirow{3}{*}{ Work of Mother } & \multicolumn{4}{|c|}{ Primigravidae } & \multicolumn{4}{|c|}{ Multigravidae } \\
\hline & \multicolumn{2}{|c|}{ Malformations } & \multicolumn{2}{|r|}{ Controls } & \multicolumn{2}{|c|}{ Malformations } & \multicolumn{2}{|r|}{ Controls } \\
\hline & No. & Percentage & No. & Percentage & No. & Percentage & No. & Percentage \\
\hline $\begin{array}{ll}\text { No work } . . & . . \\
\text { Own housework with help } & . . \\
\text { Own housework without help } \\
\text { Remunerated employment only } \\
\text { Remunerated employment and own }\end{array}$ & $\begin{array}{r}8 \\
27 \\
95 \\
59\end{array}$ & $\begin{array}{r}2 \cdot 40 \\
8 \cdot 08 \\
28 \cdot 44 \\
17 \cdot 66\end{array}$ & $\begin{array}{r}4 \\
15 \\
104 \\
17\end{array}$ & $\begin{array}{r}1 \cdot 59 \\
5 \cdot 95 \\
41 \cdot 27 \\
6 \cdot 75\end{array}$ & $\begin{array}{r}9 \\
52 \\
266 \\
14\end{array}$ & $\begin{array}{r}2 \cdot 15 \\
12 \cdot 41 \\
63 \cdot 48 \\
3 \cdot 34\end{array}$ & $\begin{array}{r}19 \\
27 \\
365 \\
6\end{array}$ & $\begin{array}{r}3 \cdot 88 \stackrel{\varrho}{\rightleftharpoons} \\
5 \cdot 51 \\
74 \cdot 49 \\
1 \cdot 22\end{array}$ \\
\hline $\begin{array}{l}\text { housework with help } \\
\text { Remunerated employment and own }\end{array}$ & 37 & $11 \cdot 08$ & 27 & $10 \cdot 71$ & 9 & $2 \cdot 15$ & 7 & $1 \cdot 43$ \\
\hline housework without help & 108 & $32 \cdot 34$ & 85 & $33 \cdot 73$ & 69 & $16 \cdot 47$ & 65 & $13 \cdot 47$ \\
\hline Total & 334 & $100 \cdot 00$ & 252 & $100 \cdot 00$ & 419 & $100 \cdot 00$. & 490 & $100 \cdot 00$ \\
\hline Total engaged remuneratively & 204 & $61 \cdot 08 \pm 2 \cdot 67$ & 129 & $51 \cdot 19 \pm 3 \cdot 15$ & 92 & $21 \cdot 96 \pm 2 \cdot 02$ & 79 & $16 \cdot 12 \pm 1 \cdot 66$ \\
\hline $\begin{array}{l}\text { Differences between percentages } \\
\text { (Malformations-Controls) }\end{array}$ & \multicolumn{4}{|c|}{$9 \cdot 89 \% \pm 4 \cdot 13$} & \multicolumn{4}{|c|}{$5 \cdot 84 \% \pm 2 \cdot 61$} \\
\hline
\end{tabular}

labour. Hydramnios is a not uncommon complication of pregnancies which result in a congenital malformation, being particularly frequent in cases of anencephalus (Drillien, 1947), and no doubt many of the cases of premature labour in our series were due to the mechanical distension of the uterus from this cause.

\section{Maternal Occupation during Pregnancy}

Information was obtained in the field enquiry about the work done during pregnancy by mothers in the malformation and control groups, and the increased proportion of mothers in remunerated $\frac{D}{5}$ employment during the war years is demonstrated separately for primigravidae and multigravidae in $N$ Table XLIII. In 1943, 38 per cent. of mothers were remuneratively employed at the onset of $N$ pregnancy, the figures being 61 per cent. and $\omega$ 23 per cent. for primigravidae and multigravidae

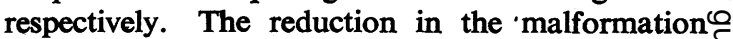
rates over these years has already been discussed, and no conspicuous association with the incidence of maternal employment is evident. This problem is further investigated in Table XLIV which shows 
TABLE XLV

Occupation of Mothers at the Onset of Pregnancy

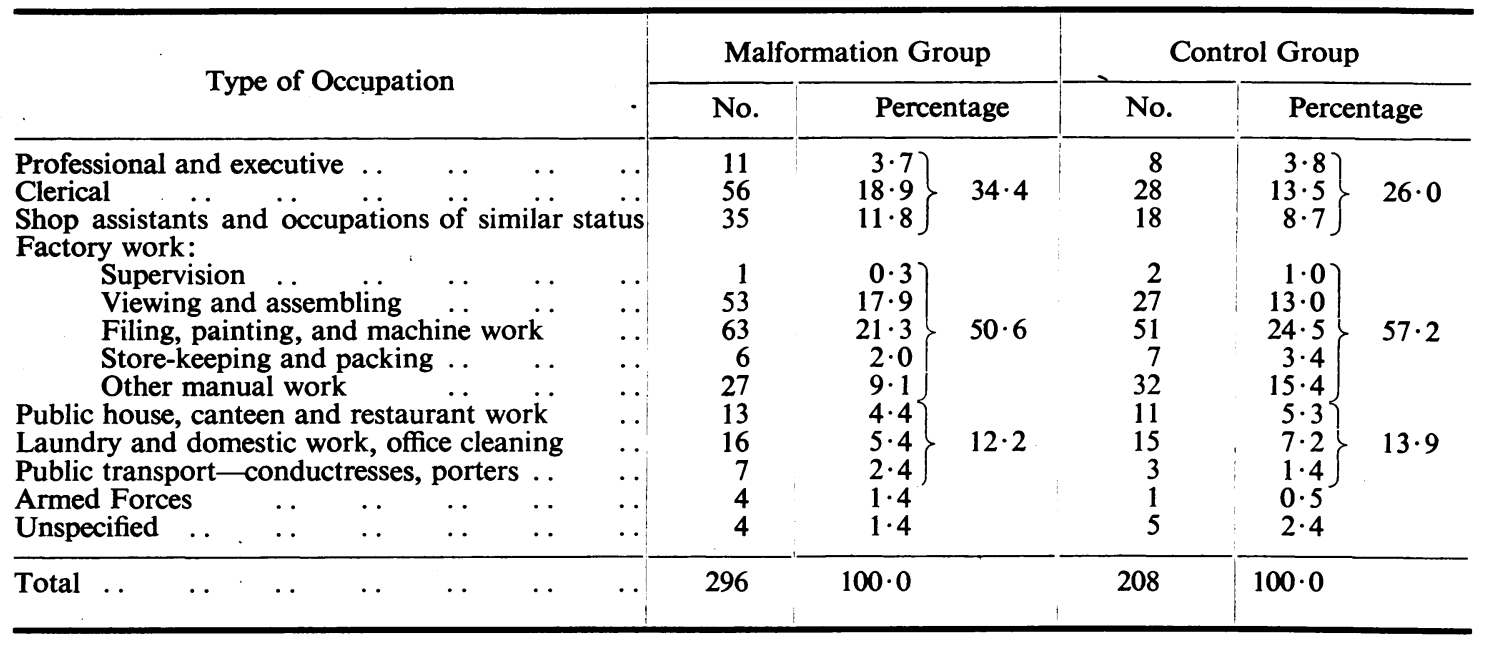

TABLE XLVI

Stage of Pregnancy when Mothers ceased Employment

\begin{tabular}{|c|c|c|c|c|c|c|c|c|c|c|}
\hline \multirow{3}{*}{\multicolumn{3}{|c|}{ Duration of Gestation (weeks) }} & \multicolumn{4}{|c|}{ Primigravidae } & \multicolumn{4}{|c|}{ Multigravidae } \\
\hline & & & \multicolumn{2}{|c|}{ Malformations } & \multicolumn{2}{|c|}{ Controls } & \multicolumn{2}{|c|}{ Malformations } & \multicolumn{2}{|c|}{ Controls } \\
\hline & & & No. & Percentage & No. & Percentage & No. & Percentage & No. & Percentage \\
\hline $\begin{array}{ll}\text { Less than } & 12 \\
12-15 & \ldots \\
16-19 & \ldots \\
20-23 & \ldots \\
24-27 & \ldots \\
28-31 & \ldots \\
32-35 & \ldots \\
36-39 & \ldots \\
40+ & . \\
\text { Unspecified } & \end{array}$ & $\begin{array}{l}\ldots \\
\ldots \\
\ldots \\
\cdots \\
\cdots \\
\ldots \\
\cdots \\
\cdots \\
\cdots\end{array}$ & $\begin{array}{l}. \\
\cdots \\
\cdots \\
\therefore \\
\therefore \\
\therefore \\
\therefore \\
\therefore\end{array}$ & $\begin{array}{r}32 \\
31 \\
31 \\
35 \\
41 \\
25 \\
5 \\
3 \\
1\end{array}$ & $\begin{array}{r}15 \cdot 7 \\
15 \cdot 2 \\
15 \cdot 2 \\
17 \cdot 2 \\
20 \cdot 1 \\
12 \cdot 2 \\
2 \cdot 4 \\
1 \cdot 5 \\
\overline{0} \cdot 5\end{array}$ & $\begin{array}{r}14 \\
33 \\
14 \\
21 \\
20 \\
13 \\
9 \\
4 \\
1 \\
-\end{array}$ & $\begin{array}{l}10 \cdot 8 \\
25 \cdot 6 \\
10 \cdot 8 \\
16 \cdot 3 \\
15 \cdot 5 \\
10 \cdot 1 \\
7 \cdot 0 \\
3 \cdot 1 \\
0 \cdot 8 \\
-\end{array}$ & $\begin{array}{r}16 \\
19 \\
8 \\
14 \\
14 \\
9 \\
5 \\
4 \\
3 \\
-\end{array}$ & $\begin{array}{r}17 \cdot 4 \\
20 \cdot 7 \\
8 \cdot 7 \\
15 \cdot 2 \\
15 \cdot 2 \\
9 \cdot 8 \\
5 \cdot 4 \\
4 \cdot 3 \\
3 \cdot 3 \\
-\end{array}$ & $\begin{array}{r}9 \\
8 \\
5 \\
16 \\
13 \\
10 \\
5 \\
10 \\
2 \\
1\end{array}$ & $\begin{array}{r}11 \cdot 4 \\
10 \cdot 1 \\
6 \cdot 3 \\
20 \cdot 3 \\
16 \cdot 5 \\
12 \cdot 7 \\
6 \cdot 3 \\
12 \cdot 7 \\
2 \cdot 5 \\
1 \cdot 3\end{array}$ \\
\hline Total & $\cdots$ & .. & 204 & $100 \cdot 0$ & 129 & $100 \cdot 0$ & 92 & $100 \cdot 0$ & 79 & $100 \cdot 0$ \\
\hline Mean (weeks) & $\cdots$ & .. & \multicolumn{2}{|r|}{$20 \cdot 6$} & \multicolumn{2}{|r|}{$21 \cdot 1$} & \multicolumn{2}{|r|}{$21 \cdot 2$} & \multicolumn{2}{|r|}{$24 \cdot 5$} \\
\hline
\end{tabular}

for primigravidae and multigravidae of the malformation and control series the circumstances in respect of work in early pregnancy; the proportion of mothers remuneratively employed is higher for the malformations. Table XLV records the type of work done, and shows a slightly higher percentage of manual workers in the employed of the control group. Information obtained about the stage in pregnancy in which mothers left regular employment (Table XLVI) shows slight differences between the two groups, which could be explained by the more frequent premature onset of labour in the malformations.
The data here recorded about employment of women in pregnancy during and since the war have some intrinsic interest. It is, however, necessary to be cautious about drawing any conclusion from differences between control and malformation groups of the dimensions shown in the accompanying tables, and we limit our conclusion to the statement that there is at least no noteworthy association between the proportion of mothers remuneratively employed and the incidence of congenital malformations of the nervous system. 


\section{SUMMARY}

1. In the years 1939 to 1945 , congenital malformations in Scotland were responsible for $11 \cdot 7$ per cent. of the certified deaths of infants stillborn or dead within the first year of life. National statistics for England and Wales do not give the causes of stillbirths but, in the years 1941 to 1945 , attribute to the same causes about 10 per cent. of first year deaths.

2. Scottish data (1941-45) show that malformations of the central nervous system accounted for at least 72 per cent. of stillborn and 39 per cent. of live born malformations which died in the first year of life, or for 55 per cent. of the combined total.

3. Data from Birmingham Maternity and Child Welfare Department records are examined in respect of 930 consecutive malformations of the central nervous system certified as the cause of stillbirths or of first year deaths in the city in the years 1940 to 1947. They were classified as follows: anencephalus (366); spina bifida (389); hydrocephalus (150); others (25). From this material evidence is provided of:

(a) The frequency with which different types of malformation are associated in one individual.

(b) The sex-ratio of the central nervous malformations.

(c) Secular trends. The rate for hydrocephalus remained fairly constant in the 8-year period. The rates for anencephalus and spina bifida declined, and it is suggested that the observed reduction may be accounted for by the change in parity of the mothers.

4. By home visits additional information was obtained from mothers of 755 of the 930 malformations, and from mothers of 742 of 876 births not resulting in malformations, selected by taking every 200th name from the registers of live and stillbirths for the same years.

5. The association of the age and parity of the mother with the risk of birth of a central nervous malformation was examined in a comparison of the malformation and control groups, with the following results:

(a) Considering all the central nervous malformations together, risks of the birth of a malformation are considerably increased at the first parity and above the sixth, and are correspondingly reduced between these extremes. Variations in association with maternal age are also present but are less marked.

(b) Considering the main groups separately, results for anencephalus and spina bifida are similar to those for the whole series. In the case of hydrocephalus, the effect of birth rank is slight when compared with the marked effect of high maternal age.

6. Locality of domicile, rent of house, and legitimacy of the birth were used as indices of social status; they do not reveal any notable differences in the incidence of central nervous malformations.

7. The incidence of maternal illness or of other maternal disability during pregnancy is recorded. $\overrightarrow{\vec{F}}$ There was no history of rubella or of other virusinfection during the pregnancies resulting in the 755 malformations of the central nervous system.

8. Information is also recorded about maternal $\widehat{\nabla}$ employment during pregnancy. There was no noteworthy association between the proportion of ${ }^{\infty}$ mothers remuneratively employed and the incidence $\vec{O}$ of congenital malformations of the nervous system.

Many people assisted the work of this enquiry, and we

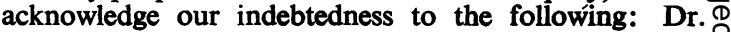
Jean Mackintosh and members of the Birmingham $\supset$ Maternity and Child Welfare Department who co-opera- $\omega$ ted fully in making available to us the records of the $\rightarrow$ department; Dr. Dorothy Tidmas, who completed a $\vec{\infty}$ preliminary survey of the malformations of one year; $\omega$ Mrs. Kathleen Gibson, Miss Mary Edge, Mrs. Burgess 음 Smith, Mrs. Leaver, Miss Day, Miss Bayes, and members of the Almoners' Department of the United Birmingham $\overrightarrow{-}$ Hospitals, all of whom took part in the field work; and $\bigcirc$ Miss Catherine Wall, who prepared the figures used in $\frac{0}{0}$ the text. Dr. Enid Charles and Sir Leonard Parsons read the typescript and offered useful suggestions. Finally, and in particular, we record our gratitude to Prof. $\vec{\varphi}$ Lancelot Hogben, F.R.S., who has contributed most generously to this enquiry.

\section{REFERENCES}

Allen, F. M. B., Macaffee, C. H. G., and Biggart, J. (1943). J. Obstet. Gynaec. Brit. Emp., 50, 417.

Baird, D. (1947). Lancet, 2, 531.

Burke, B. S., Beal, V. A., Kirkwood, S. B., and Stuart, H. C. (1943). Amer. J. Obstet. Gynec., 46, 38.

Cruickshank, J. N. (1930). Med. Res. Coun. Spec. Rep. O Ser. Lond. No. 145.

D'Esopo, D. A., and Marchetti, A. A. (1942). Amer. J. Obstet. Gynec., 44, 1.

Dogramaci, I., and Green, H. (1947). J. Pediat., 30, 295.

Drillien, C. M. (1947). J. Obstet. Gynaec. Brit. Emp., $54,452$.

Evans, M., and Smith, G. S. (1946). Ibid., 53, 440.

Fox, M. J., and Bortin, M. M. (1946). J. Amer. med. \& Ass., 130, 568.

, Krumbiegel, E. R., and Teresi, J. L. (1948). Lancet, 1, 746.

Gérard-Lefebvre and Merlen, J. (1948). Sem. Hôp. Paris, 24, 2541.

Greenhill, J. P. (1923). Surg. Gynec. Obstet., 36, 227. (1939). Amer. J. Obstet. Gynec., 37, 624.

Gruenwald, P. (1947). Arch. Path., 44, 398.

Hale, F. (1933). J. Hered., 24, 105.

Hellman, A. M., and Simon, H. J. (1935). Amer. J. N Surg., 29, 403.

Hertig, A. T., and Livingstone, R. G. (1944). New Eng.

J. Med., 230, 797.
Hill, A. Bradford, and Galloway, T. McL. (1949). $\frac{\varrho}{\mathscr{C}}$ Lancet, 1, 299.

Hindse-Nielsen (1938). Acta chir. scand., 80, 525.

Hogben, L. (1933). "Nature and Nurture", George T Allen \& Unwin, London.

Holt, S. B. (1948). Ann. Eugen. Camb., 14, 144. 
" International Statistical Classification of Diseases, Injuries and Causes of Death" (1948). Vol. 1, W.H.O., Geneva.

Javert, C. T., and Stander, H. J. (1943). Surg. Gynec. Obstet., 76, 115.

Kotz, J., Parker, E., and Kaufman, M. S. (1941). J. clin. Endocrin., 1, 838.

Leitch, I. (1944). Proc. Nutr. Soc., 1, 247.

Lenart, G. (1941). Ann. Paediat., Basel, 157, 216.

Macklin, M. T. (1929). Hum. Biol., 1, 382.

Mall, F. P. (1917). Amer. J. Anat., 22, 49.

Malpas, P. (1937). J. Obstet. Gynaec. Brit. Emp., $44,434$.

Martin, W. J. (1949). Brit. med. J., 1, 438.

Murphy, D. P. (1940). "Congenital Malformations", University of Pennsylvania Press, Philadelphia (1947). 2nd ed., J. B. Lippincott Co., Philadelphia. Newton, L., and McLean, T. S. (1947). Conn. med. J., - 11, 617.

Ober, R. E., Horton, R. J. M., and Feemster, R. F. (1947). Amer. J. publ. Hlth, 37, 1328.
Parsons, L. G. (1946). Brit. med. Bull., 4, 193.

Penrose, L. S. (1934). Ann. Eugen., Camb., 6, 108. (1946). Ibid., 13, 73. (1948). Brit. med. J., 2, 99.

Potter, E. L., and Adair, F. L. (1943). Amer. J. Obstet. Gynec., 45, 1054.

- and Dieckmann, W. J. (1948). Ibid., 56, 593.

Rock, J., and Hertig, A. T. (1948). Ibid., 55, 6.

Shute, E. (1939). Ibid., 37, 633 (discussion).

Siegel, I. A. (1934). Ibid., 27, 889.

Skipper, E. (1933). Quart. J. Med., 26 (N.S. ii), 353.

Still, G. F. (1927). Lancet, 2, 795.

Suter, M., and Wichser, C. (1948). Amer. J. Obstet. Gynec., 55, 489.

Warkany, J. (1945). Milbank Mem. Fd Quart., 23, 66. (1947). Adv. Pediat., 2, 1.

Roth, C. B., and Wilson, J. G. (1948). Pediatrics, 1, 462.

White, P. (1935). Surg. Gynec. Obstet., 61, 324.

Woolf, B. (1946). Brit. med. Bull., 4, 170.

\section{APPENDIX A}

\section{Classification of Birmingham City Wards into Three Social Groups}

In Birmingham certain statistics can be prepared separately for each city ward, and since alternative indices of social status are often not available, a classification of wards into social groups is of value. For many years the annual reports of the Medical Officer of Health have given statistics for central, inner and outer rings, a classification based on the wards and related broadly to social differences. This classification introduces certain anomalies: Edgbaston, for example, is in the inner ring, but having been reserved as a high-class residential area, contains few working-class dwellings; in the outer ring some wards have a high proportion of municipally-owned houses occupied by residents of the artisan class, while others have mainly privatelyowned houses, many occupied by professional and business men. We have therefore re-classified the wards, using data from three sources:

(1) The Housing Survey Report, 1946, gives for each ward the number of houses: (a) back-to-back; (b) with a bathroom; $(c)$ with a bath; $(d)$ municipally-owned.

(2) The Birmingham City Statistical Office* has supplied the average rateable values for each ward.

(3) The Town Planning Department gave the surface area of each ward, from which were calculated by wards: (a) housing densities; (b) population densities, using the ward population given in the Report of the Medical Officer of Health, 1947.

Table A and Fig. A (overleaf) give the data on which the 34 city wards were divided into three groups:

\footnotetext{
* We are indebted for this material to Dr. Enid Charles.
}

Group I. Fifteen wards with a high proportion of substandard houses. These include all the central wards and the more highly industrialized wards of the inner ring; it accommodates mainly the families of workers with low incomes.

Group II. Twelve wards with houses of a higher standard than Group I. The most significant feature is the high proportion of municipallyowned houses in eight wards. These houses are also occupied mainly by working-class families.

Group III. Seven wards with a high general level of housing. All except Edgbaston are in the outer ring and well removed from the industrial areas.

Infant mortality and live birth rates for the years 1946 and 1947 show considerable differences between the three ward groups. (Table B, overleaf, and Fig. B, below.)

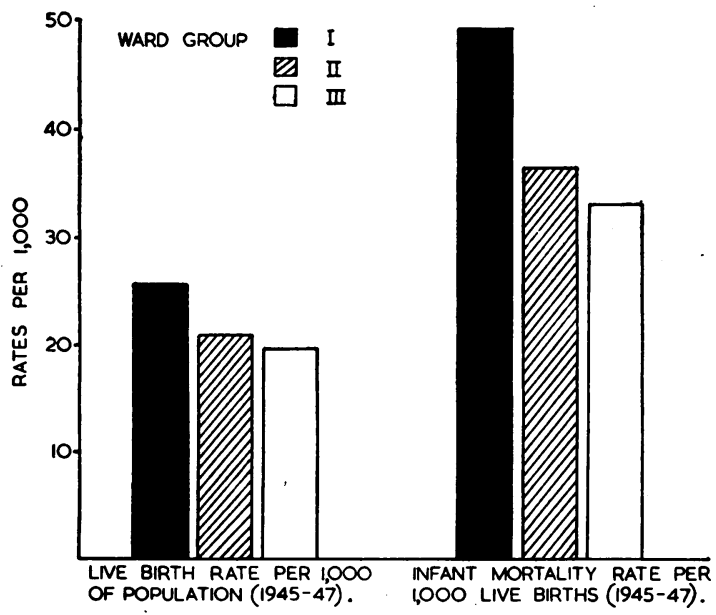

FIG. B.-Birth rate and infant mortality rate by ward groups (Birmingham, 1946-47). 


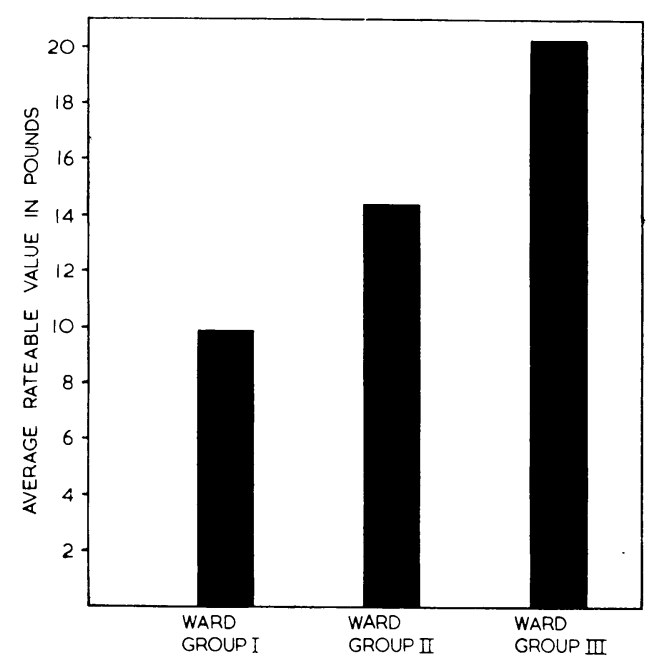

(a) RATEABLE VALUE

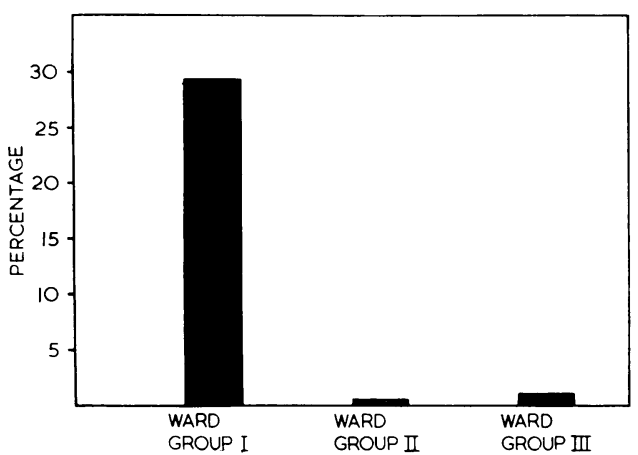

(c) BACK-TO-BACK HOUSES

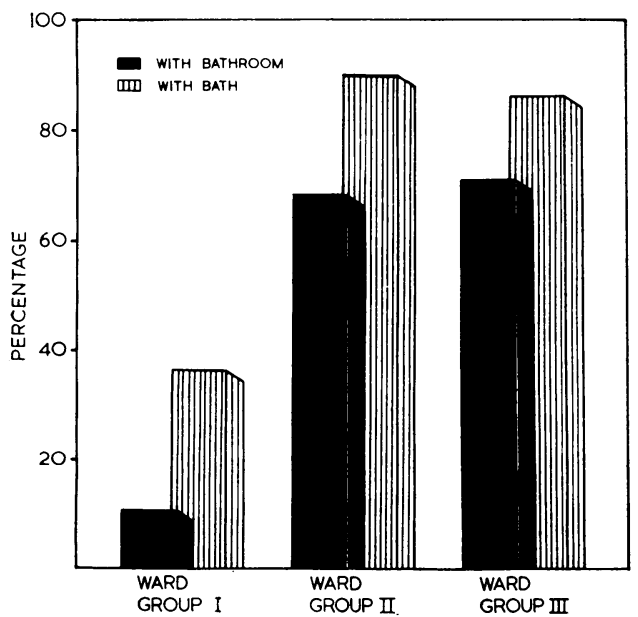

(e) HOUSES WITH BATHS AND BATTHROOMS

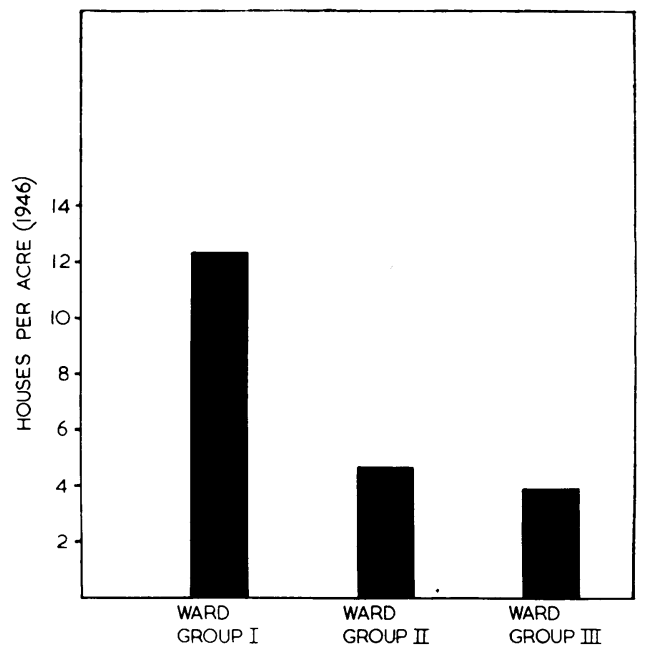

(b) HOUSING DENSITY

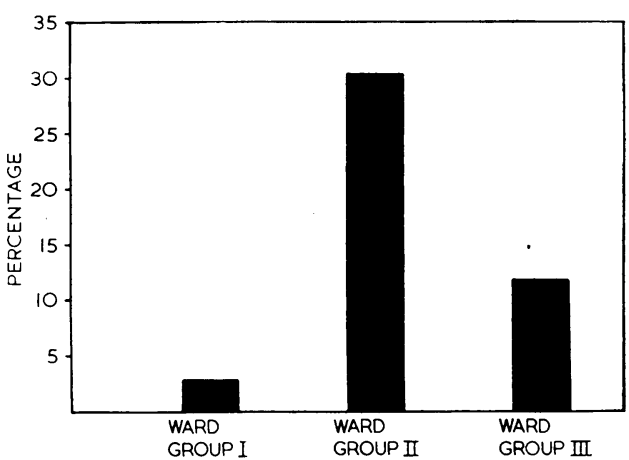

(d) MUNICIPAL HOUSES

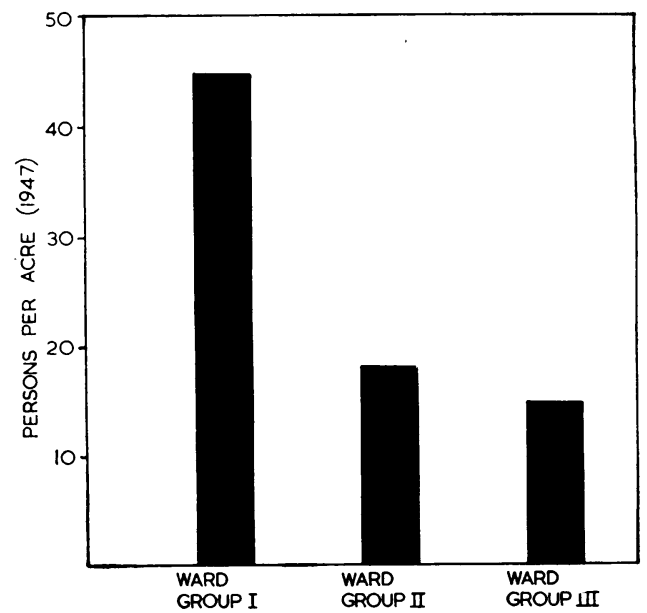

(f) POPULATION DENSITY

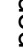

윽

쿵

FIG. A.-Housing details by ward groups (Birmingham, 1946-47). 
APPENDIX A, TABLE A

Housing Statistics of Ward Groups IN Birmingham (1946)

\begin{tabular}{|c|c|c|c|c|c|c|c|c|c|}
\hline \multirow{2}{*}{\multicolumn{3}{|c|}{ Municipal Ward }} & \multicolumn{4}{|c|}{ Percentage of Dwelling Houses } & \multirow{2}{*}{$\begin{array}{c}\text { Average } \\
\text { Rateable } \\
\text { Value } \\
(1947) \\
£\end{array}$} & \multicolumn{2}{|c|}{$\begin{array}{l}\text { Housing and Popula- } \\
\text { tion Density }\end{array}$} \\
\hline & & & $\begin{array}{l}\text { Back-to- } \\
\text { back type }\end{array}$ & $\begin{array}{c}\text { With } \\
\text { bathroom }\end{array}$ & $\begin{array}{l}\text { With } \\
\text { bath }\end{array}$ & $\begin{array}{c}\text { Munici- } \\
\text { pally } \\
\text { owned }\end{array}$ & & $\begin{array}{l}\text { Houses } \\
\text { per Acre }\end{array}$ & $\begin{array}{l}\text { Persons } \\
\text { per Acre }\end{array}$ \\
\hline \multicolumn{3}{|c|}{ 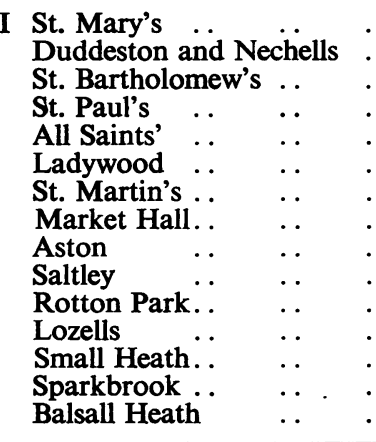 } & $\begin{array}{l}47 \cdot 2 \\
29 \cdot 1 \\
26 \cdot 7 \\
63 \cdot 8 \\
29 \cdot 9 \\
61 \cdot 0 \\
49 \cdot 7 \\
64 \cdot 7 \\
24 \cdot 8 \\
1 \cdot 9 \\
26 \cdot 5 \\
21 \cdot 1 \\
4 \cdot 4 \\
7 \cdot 5 \\
11 \cdot 0\end{array}$ & $\begin{array}{r}3 \cdot 9 \\
3 \cdot 8 \\
6 \cdot 8 \\
2 \cdot 0 \\
2 \cdot 5 \\
3 \cdot 2 \\
8 \cdot 5 \\
4 \cdot 8 \\
5 \cdot 9 \\
29 \cdot 5 \\
15 \cdot 5 \\
5 \cdot 0 \\
27 \cdot 9 \\
16 \cdot 7 \\
15 \cdot 9\end{array}$ & $\begin{array}{l}27 \cdot 1 \\
29 \cdot 8 \\
22 \cdot 5 \\
38 \cdot 3 \\
45 \cdot 1 \\
20 \cdot 9 \\
31 \cdot 2 \\
28 \cdot 4 \\
37 \cdot 9 \\
49 \cdot 0 \\
42 \cdot 6 \\
31 \cdot 8 \\
57 \cdot 6 \\
34 \cdot 4 \\
35 \cdot 4\end{array}$ & $\begin{array}{r}0 \cdot 0 \\
2 \cdot 6 \\
6 \cdot 7 \\
0 \cdot 0 \\
0 \cdot 4 \\
0 \cdot 6 \\
5 \cdot 3 \\
0 \cdot 0 \\
0 \cdot 0 \\
13 \cdot 4 \\
0 \cdot 0 \\
0 \cdot 5 \\
13 \cdot 7 \\
0 \cdot 0 \\
0 \cdot 0\end{array}$ & $\begin{array}{r}7 \cdot 61 \\
7 \cdot 84 \\
7 \cdot 90 \\
7 \cdot 93 \\
8 \cdot 43 \\
8 \cdot 45 \\
8 \cdot 98 \\
9 \cdot 20 \\
9 \cdot 25 \\
11 \cdot 03 \\
11 \cdot 34 \\
11 \cdot 63 \\
11 \cdot 70 \\
11 \cdot 75 \\
11 \cdot 95\end{array}$ & $\begin{array}{r}10 \cdot 7 \\
12 \cdot 2 \\
9 \cdot 0 \\
12 \cdot 8 \\
15 \cdot 8 \\
19 \cdot 0 \\
12 \cdot 3 \\
9 \cdot 1 \\
14 \cdot 1 \\
6 \cdot 4 \\
12 \cdot 0 \\
19 \cdot 5 \\
13 \cdot 3 \\
11 \cdot 4 \\
18 \cdot 1\end{array}$ & $\begin{array}{l}41 \cdot 6 \\
44 \cdot 3 \\
32 \cdot 1 \\
44 \cdot 0 \\
52 \cdot 8 \\
65 \cdot 0 \\
46 \cdot 2 \\
32 \cdot 1 \\
50 \cdot 7 \\
24 \cdot 0 \\
42 \cdot 1 \\
70 \cdot 8 \\
50 \cdot 4 \\
45 \cdot 2 \\
64 \cdot 2\end{array}$ \\
\hline \multicolumn{2}{|c|}{ Average for Group I } & .. & $29 \cdot 3$ & $10 \cdot 8$ & $36 \cdot 5$ & $2 \cdot 87$ & $9 \cdot 86$ & $12 \cdot 38$ & $44 \cdot 76$ \\
\hline II & 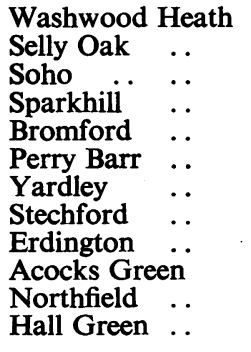 & $\begin{array}{l}. \\
\cdots \\
\because \\
\because \\
\because \\
\because \\
\because \\
\cdots \\
\cdots \\
\cdots \\
\cdots\end{array}$ & $\begin{array}{l}0 \cdot 8 \\
0 \cdot 7 \\
5 \cdot 2 \\
0 \cdot 5 \\
3 \cdot 0 \\
0 \cdot 0 \\
0 \cdot 2 \\
0 \cdot 0 \\
0 \cdot 7 \\
0 \cdot 1 \\
0 \cdot 1 \\
0 \cdot 0\end{array}$ & $\begin{array}{l}62 \cdot 7 \\
53 \cdot 8 \\
41 \cdot 9 \\
52 \cdot 0 \\
44 \cdot 7 \\
86 \cdot 5 \\
62 \cdot 7 \\
89 \cdot 7 \\
61 \cdot 7 \\
56 \cdot 1 \\
82 \cdot 9 \\
72 \cdot 8\end{array}$ & $\begin{array}{l}81 \cdot 8 \\
82 \cdot 6 \\
77 \cdot 6 \\
67 \cdot 6 \\
78 \cdot 2 \\
99 \cdot 8 \\
88 \cdot 6 \\
98 \cdot 7 \\
87 \cdot 8 \\
94 \cdot 0 \\
95 \cdot 9 \\
99 \cdot 5\end{array}$ & $\begin{array}{r}17 \cdot 4 \\
9 \cdot 6 \\
1 \cdot 7 \\
2 \cdot 7 \\
32 \cdot 7 \\
35 \cdot 3 \\
28 \cdot 4 \\
42 \cdot 4 \\
39 \cdot 4 \\
44 \cdot 8 \\
38 \cdot 9 \\
41 \cdot 6\end{array}$ & $\begin{array}{l}12 \cdot 94 \\
13 \cdot 91 \\
15 \cdot 60 \\
16 \cdot 13 \\
13 \cdot 46 \\
13 \cdot 47 \\
13 \cdot 84 \\
13 \cdot 89 \\
14 \cdot 54 \\
14 \cdot 58 \\
14 \cdot 65 \\
16 \cdot 37\end{array}$ & $\begin{array}{l}4 \cdot 9 \\
5 \cdot 3 \\
9 \cdot 2 \\
7 \cdot 6 \\
2 \cdot 9 \\
6 \cdot 1 \\
6 \cdot 5 \\
3 \cdot 1 \\
7 \cdot 0 \\
7 \cdot 4 \\
2 \cdot 3 \\
6 \cdot 3\end{array}$ & $\begin{array}{l}19 \cdot 1 \\
18 \cdot 6 \\
33 \cdot 6 \\
27 \cdot 6 \\
11 \cdot 7 \\
25 \cdot 3 \\
25 \cdot 5 \\
13 \cdot 1 \\
28 \cdot 3 \\
30 \cdot 0 \\
8 \cdot 3 \\
24 \cdot 8\end{array}$ \\
\hline \multicolumn{2}{|c|}{ Average for Group II } & .. & 0.6 & $68 \cdot 4$ & $90 \cdot 0$ & $30 \cdot 3$ & $14 \cdot 40$ & $4 \cdot 63$ & $18 \cdot 15$ \\
\hline III & $\begin{array}{l}\text { King's Norton } \\
\text { Gravelly Hill } \\
\text { Sandwell .. } \\
\text { Harborne .. } \\
\text { Handsworth. } \\
\text { Moseley and King's } \\
\text { Edgbaston ... }\end{array}$ & $\begin{array}{l}\cdots \\
\cdots \\
\cdots \\
\cdots \\
\text { s Heath. } \\
.\end{array}$ & $\begin{array}{l}0 \cdot 3 \\
0 \cdot 2 \\
0 \cdot 4 \\
0 \cdot 2 \\
1 \cdot 7 \\
0 \cdot 1 \\
5 \cdot 8\end{array}$ & $\begin{array}{l}73 \cdot 4 \\
75 \cdot 0 \\
56 \cdot 3 \\
76 \cdot 9 \\
60 \cdot 1 \\
74 \cdot 0 \\
75 \cdot 4\end{array}$ & $\begin{array}{l}82 \cdot 8 \\
86 \cdot 0 \\
77 \cdot 6 \\
86 \cdot 8 \\
85 \cdot 4 \\
91 \cdot 5 \\
88 \cdot 9\end{array}$ & $\begin{array}{r}11 \cdot 3 \\
21 \cdot 9 \\
2 \cdot 5 \\
15 \cdot 1 \\
1 \cdot 4 \\
21 \cdot 7 \\
0 \cdot 0\end{array}$ & $\begin{array}{l}16 \cdot 50 \\
16 \cdot 58 \\
17 \cdot 77 \\
18 \cdot 80 \\
19 \cdot 16 \\
20 \cdot 80 \\
34 \cdot 81\end{array}$ & $\begin{array}{l}3 \cdot 0 \\
4 \cdot 1 \\
4 \cdot 1 \\
4 \cdot 2 \\
5 \cdot 6 \\
4 \cdot 5 \\
2 \cdot 8\end{array}$ & $\begin{array}{l}11 \cdot 0 \\
17 \cdot 7 \\
14 \cdot 2 \\
14 \cdot 9 \\
21 \cdot 2 \\
17 \cdot 5 \\
11 \cdot 5\end{array}$ \\
\hline Aver & rage for Group III & . & $1 \cdot 1$ & $71 \cdot 1$ & $86 \cdot 1$ & $11 \cdot 8$ & $20 \cdot 27$ & $3 \cdot 87$ & $14 \cdot 77$ \\
\hline Who & ole City & & $10 \cdot 3$ & $49 \cdot 7$ & $71 \cdot 3$ & $17 \cdot 1$ & - & $5 \cdot 56$ & $21 \cdot 08$ \\
\hline
\end{tabular}

APPENDIX A, TABLE B

Vital Statistics of WARD Groups IN Birmingham (1946-1947)

\begin{tabular}{|c|c|c|c|c|}
\hline \multirow{2}{*}{ Vital Statistics } & \multicolumn{3}{|c|}{ Ward Group } & \multirow{2}{*}{ All Wards } \\
\hline & $\mathbf{I}$ & II & III & \\
\hline $\begin{array}{lll}\text { Birth rate } & \ldots & \ldots\end{array}$ & $25 \cdot 7$ & $21 \cdot 0$ & $19 \cdot 7$ & $22 \cdot 4$ \\
\hline Infant mortality rate & $49 \cdot 2$ & $36 \cdot 5$ & $33 \cdot 1$ & $40 \cdot 4$ \\
\hline
\end{tabular}

